\title{
DOWNSTREAM AND UPSTREAM \\ GREENHOUSE GAS EMISSIONS: THE PROPER SCOPE OF NEPA REVIEW
}

\author{
Michael Burger* E Jessica Wentz**
}

\begin{abstract}
Recently, legal controversies have arisen regarding the scope of greenhouse gas emissions that should be considered in environmental reviews of fossil fuel extraction and transportation proposals under the National Environmental Policy Act ("NEPA"). The key question is whether and how agencies should account for emissions from activities that occur "downstream" from the proposed action, such as the combustion of fossil fuels, and emissions from activities that occur "upstream" of the proposed action, such as the extraction of fossil fuels. This question is important, because consideration of such emissions can alter the balance of costs and benefits for a proposed project and the agency's ability to justify approving the project in light of that balance.

This Article argues that such emissions do typically fall within the scope of indirect and cumulative impacts that must be evaluated under NEPA, and provides recommendations on how agencies should evaluate such emissions in environmental review documents. To support the argument and recommendations, the Article makes several unique contributions to the growing literature on NEPA and climate change. First, we describe how federal approvals of fossil fuel extraction and infrastructure contribute to global climate change, and we explain why federal agencies have ample discretion to account for these impacts when deciding whether to issue such approvals. Second, we conduct an in-depth examination of NEPA's requirements as they pertain to the analysis of downstream and upstream emissions, focusing in particular on the requirements to evaluate indirect effects, cumulative effects, and effects from related actions. Third, we describe how federal agencies currently account for downstream and upstream greenhouse gas emissions in their NEPA reviews, and we find that there are major inconsistencies in the analytical approaches both within and across agencies, but many agencies are nonetheless beginning to recognize that upstream and downstream emissions fall within the scope of impacts that should be reviewed under NEPA. Fourth, we synthesize all of the existing case law on this subject, and we find that courts have generally treated such emissions as the type of indirect effects that must be evaluated in a NEPA reviews. Finally, we outline an approach for evaluating upstream and downstream emissions that would improve the quality of federal decision-making, improve agencies' chances in litigation, and provide muchneeded information about the indirect and cumulative effects of fossil fuel development on global climate change.
\end{abstract}

* Michael Burger is the Executive Director of the Sabin Center for Climate Change Law, and a research scholar and Lecturer-in-Law at Columbia Law School. The authors would like to thank Michael Gerrard and the editors of the Harvard Environmental Law Review for their input on this paper.

* Jessica Wentz is a staff attorney at the Sabin Center for Climate Change Law and an associate research scholar at Columbia Law School. 


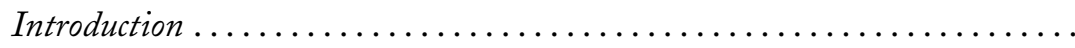

I. Federal Decision-making, Fossil Fuel Development and Greenhouse

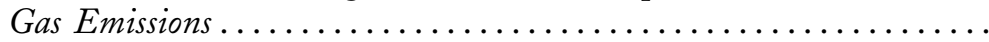

A. Federal Authority over the Extraction of Fossil Fuels from Federal Lands ..................................

B. Federal Authority over the Transportation and Processing of Fossil Fuels ....................................

C. Greenhouse Gas Emissions from Fossil Fuels Produced from

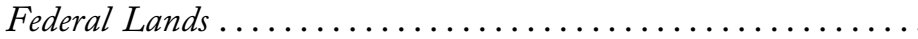

D. Greenhouse Gas Emissions from Transportation and Processing

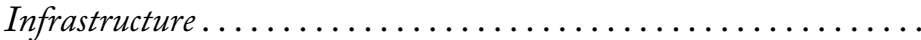

II. The National Environmental Policy Act: Statute and

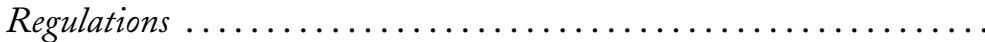

A. The National Environmental Policy Act ................ 127

B. NEPA Regulations.............................. 128

C. Agency Guidance............................... 130

III. An Agency-by-Agency Look at the Scope of Existing Federal Analysis of Upstream and Downstream Greenhouse Gas Emissions Under

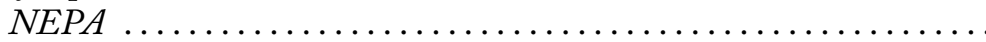

A. Bureau of Land Management ....................... 134

B. United States Forest Service ......................... 136

C. Federal Energy Regulatory Commission ................. 137

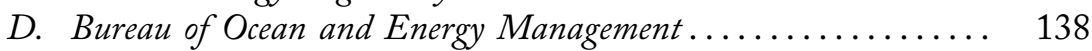

E. Department of Energy............................ 139

F. United States Army Corps of Engineers ................. 139

G. Department of State.............................. 140

H. Environmental Protection Agency .................... 141

IV. Emerging Trends in NEPA Case Law ................... 142

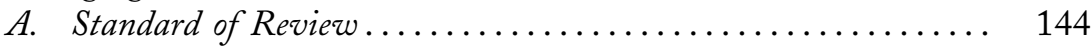

B. Indirect Effects ................................ 145

C. Effects of Related Actions .......................... 168

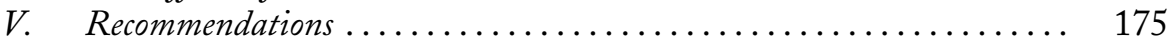

A. Fossil Fuel Extraction ............................ 176

B. Fossil Fuel Transportation Infrastructure............... 178

C. Net Emissions Analysis .......................... 179

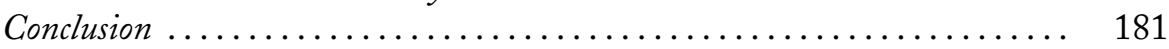

Appendix: Estimating Life-cycle Greenhouse Gas Emissions from Fossil

Fuels ............................................ 


\section{INTRODUCTION}

The nations of the world have agreed that, in order to avoid the worst impacts of climate change, we must limit global warming to "well below" a $2{ }^{\circ} \mathrm{C}$ increase above pre-industrial temperatures, and seek to limit it to $1.5^{\circ} \mathrm{C} .{ }^{1} \mathrm{It}$ is a hard pill for some to swallow, but the only way to achieve this goal is to refrain from extracting and using the majority of the planet's known fossil fuel reserves. Indeed, according to a recent scientific study, $80 \%$ of global coal reserves, 50\% of gas reserves, and about $30 \%$ of oil reserves must remain unused to meet a $2{ }^{\circ} \mathrm{C}$ target. ${ }^{2}$ Governments and industry will need to be even more conservative with these resources to keep global warming well below $2{ }^{\circ} \mathrm{C}$, or at $1.5^{\circ} \mathrm{C}$. As climate activists have put it: If the planet is to avoid the worst impacts of climate change we need to "keep it in the ground."

The United States has been slow to respond to this imperative. ${ }^{4}$ In the past decade, federal agencies have approved thousands of new leases for coal, oil, and gas development, as well as hundreds of pipelines, railways, and export terminals that are used to transport fossil fuels to domestic and international markets. ${ }^{5}$ The approval of these leases and the construction of this infrastructure locks the economy into decades of fossil fuel use and its corresponding greenhouse gas emissions. ${ }^{6}$ Take, for example, federal coal leasing- the amount

1. U.N. Framework Convention on Climate Change, Adoption of the Paris Agreement, U.N. Doc. FCCC/CP/2015/L.9/Rev.1, art.2 (Dec. 12, 2015).

2. Christophe McGlade \& Paul Ekins, The Geographical Distribution of Fossil Fuels Unused When Limiting Global Warming to $2{ }^{\circ}$ C, 517 NATURE 187, 187 (2015).

3. See, e.g., Keep It in the Ground, GreenPEAcE, https://perma.cc/CD83-ZHGY.

4. The United States is not alone in this regard. According to the International Energy Agency's statistics on fossil fuel production in 2012, U.S. production accounted for $12 \%$ of global coal production and $15 \%$ of global oil production (global totals are not available for natural gas production). In contrast, China accounted for $46 \%$ of global coal production and $5 \%$ of global oil production. International Energy Statistics, U.S. Energy Info. Admin., https://perma.cc/9C4R-CBSG.

5. See Approved Major Pipeline Projects (2009-Present), Fed. Energy Regulatory Comm'N (June 22, 2016), https://perma.cc/954K-N6A5; Coal Lease Table, BurEAu OF LAND Mgmt. (July 7, 2016), https://perma.cc/4XUX-M73A; North American LNG Import/Export Terminals, Approved, Fed. Energy Regulatory Comm'n (Sept. 21, 2016), https:// perma.cc/ACK6-VXJM; Oil and Gas Statistics, Bureau of Land Mgmt. (Apr. 11, 2016), https://perma.cc/Q4BH-6DUA; Outer Continental Shelf Lease Sale Statistics, BuREAU OF Ocean \& Energy MGMt. (2015), https://perma.cc/TT6Z-QJWK.

6. To illustrate this point, federal coal leases have initial terms of twenty years and so long thereafter as production in commercial quantities is maintained. The average length of an oil or gas lease is ten years, and the lease automatically continues so long as there is a well on the lease capable of producing in paying quantities, or the lease can receive an allocation of production from an off-lease well capable of producing in paying quantities. See BuREAU OF Land Mgmt., Form 3100-11, Offer to Lease and Lease for Oil and Gas (2008); Bureau of Land Mgmt., Form 3400-12, Coal Lease (2013); Coal, Bureau of Land 
of coal reserves already under lease are estimated to be enough to sustain current levels of production for approximately twenty years. ${ }^{7}$

A significant part of the problem is that federal agencies have been slow to use the National Environmental Policy Act ("NEPA") to fully evaluate how decisions about the extraction and transportation of fossil fuels contribute to global climate change. NEPA is designed to promote knowledge, disclosure, and accountability in federal decision-making, and to ensure that government actors are making choices based on a sound understanding of the environmental impacts of a proposed course of action. ${ }^{8}$ However, as discussed more fully in the sections that follow, federal agencies conducting environmental reviews for coal, oil and gas leases have only recently begun to disclose the downstream greenhouse gas emissions that will occur as a result of the transportation, processing, and combustion of these fuels. ${ }^{9}$ And when conducting environmental reviews for the pipelines and terminals intended to transport coal, oil, and gas to markets, agencies rarely consider the direct and indirect effects of such infrastructure on greenhouse gas emissions associated with either upstream production or downstream consumption of the transported fuels. ${ }^{10}$ Agencies also tend to evaluate the effects of each decision in isolation, rather than conducting programmatic reviews to evaluate how multiple lease approvals, pipeline authorizations, and other decisions may affect fossil fuel use and greenhouse gas emissions. The net effect of this analytic gap is that neither the agencies nor the

Mgmt., https://perma.cc/G9ZY-9XDP; Oil and Gas, Questions and Answers About Leasing, Bureau of Land MGMt. (Sept. 10, 2012), https://perma.cc/48W7-MZFP.

7. Certainty for States E Tribes Act: Hearing on H.R. 5259 Before the Subcomm. on Energy $\mathcal{E}^{\circ}$ Mineral Res. of the H. Comm. on Nat. Res., 114th Cong. 7 (2016) (statement of Amanda Leiter, Deputy Assistant Sec'y, Land \& Minerals Mgmt., U.S. Dep't of Interior); Press Release, U.S. Dep't. of Interior, Secretary Jewell Launches Comprehensive Review of Federal Coal Program (Jan. 15, 2016).

8. See, e.g., Bradley Karkkainen, Toward a Smarter NEPA: Monitoring and Managing Government's Environmental Performance, 102 Colum. L. Rev. 903, 909-16 (2002); Jonathan Poisner, A Civic Republican Perspective on the National Environmental Policy Act's Process for Citizen Participation, 26 EnvTl. L. 53, 54-55 (1996); Sidney A. Shapiro, Administrative Law After the Counter-Reformation: Restoring Faith in Pragmatic Government, 48 U. KaN. L. REv. 689, 693-96 (2000).

9. See, e.g., Bureau of Land Mgmt., UTU-84102, Final Supplemental Environmental Impact Statement for the Leasing and Underground Mining of the Greens Hollow Federal Coal Lease Tract 287 (2015); U.S. Forest Serv., Rulemaking for Colorado Roadless Areas, Supplemental Draft Environmental Impact Statement (2015).

10. Compare U.S. Dep't of State, Final Supplemental Environmental Impact Statement for the Keystone XL Project § 4.14.3, app. U (2014) (discussing life-cycle greenhouse gas emissions) with Fed. Energy Regulatory Comm'n, Final Environmental Impact Statement Golden Pass LNG Export Project (2016) (not considering upstream or downstream emissions), and Fed. Energy Regulatory Comm'n, Cameron LNG Expansion Project, Environmental Assessment (2016) (also not considering upstream or downstream emissions). 
public have a clear understanding of how these decisions impact the nation's overall climate goals.

This Article argues that consideration of how fossil fuel lease and infrastructure approvals indirectly and cumulatively effect global greenhouse gas emissions is not merely a matter of good policy-it is also required under NEPA. The statute's implementing regulations require federal agencies to consider the direct, indirect, and cumulative environmental effects of proposed actions prior to undertaking those actions. The regulations also require agencies to conduct a coordinated environmental review of "related" actions, including actions that are interdependent parts of a larger whole and actions that have cumulatively significant impacts on the environment. The purpose of these requirements is to ensure that agencies account for the full range of environmental consequences associated with their actions, both individually and in aggregate. Such a comprehensive review is necessary to fulfill NEPA's twin aims of informed decision-making and public disclosure.

The question of whether NEPA requires upstream and/or downstream greenhouse gas emissions analysis, and if so in what contexts, is presently being bandied about in the courts. ${ }^{11}$ Dozens of federal approvals related to fossil fuel development have been challenged in the past few years for failing to comply with NEPA's requirements. There are now at least seven decisions holding that agencies are required to consider upstream and/or downstream emissions in the context of certain types of proposals, such as the approval of coal leasing plans and railways intended to transport coal from mines to power plants. ${ }^{12}$ The D.C. Circuit also recently ruled that the Federal Energy Regulatory Commission ("FERC") must conduct a consolidated environmental review of gas pipeline segments, because the approvals of these segments were connected actions

11. Emissions from the production of fossil fuels are sometimes referred to as "upstream" emissions even in the context of fossil fuel production projects because they are located upstream on the fossil fuel supply chain. Throughout this paper, when discussing production projects we refer to these as "direct" emissions because they qualify as direct impacts under NEPA. When discussing transportation projects, we refer to these as "upstream" emissions because they qualify as indirect impacts under NEPA.

12. See N. Plains Res. Council, Inc. v. Surface Transp. Bd., 668 F.3d 1067, 1080 (9th Cir. 2011); S. Fork Band Council of W. Shoshone of Nev. v. U.S. Dep't of Interior, 588 F.3d 718, 725 (9th Cir. 2009); Mid States Coal. for Progress v. Surface Transp. Bd., 345 F.3d 520, 549 (8th Cir. 2003); WildEarth Guardians v. Office of Surface Mining, Reclamation \& Enft, No. CV 14-103-BLG-SPW, 2015 WL 6442724 (D. Mont. Oct. 23, 2015), report and recommendation adopted in part, rejected in part sub nom. Guardians v. Office of Surface Mining, Reclamation \& Enft, No. CV 14-103-BLG-SPW, 2016 WL 259285 (D. Mont. Jan. 21, 2016); Diné Citizens Against Ruining Our Env’t v. Office of Surface Mining, Reclamation \& Enft, 82 F. Supp. 3d 1201 (D. Colo. 2015); WildEarth Guardians v. Office of Surface Mining, Reclamation \& Enft, 104 F. Supp. 3d 1208, 1230 (D. Colo. 2015); High Country Conservation Advocates v. U.S. Forest Serv., 52 F. Supp. 3d 1174 (D. Colo. 2014). 
within the meaning of NEPA. ${ }^{13}$ There are some diverging opinions, but the emerging trend in courts examining this issue is that agencies should evaluate specific decisions about fossil fuel extraction and transportation as links in a much larger chain of fossil fuel production and consumption. ${ }^{14}$ This only makes sense. The cumulative effect of greenhouse gas emissions from fossil fuel projects in the United States is significant. In addition, greenhouse gas emissions can be meaningfully evaluated even when there is considerable uncertainty about the exact timing and location of the activities giving rise to the emissions. ${ }^{15}$

During the Obama administration some federal agencies began to change their practices in response to public pressure, court decisions and more specific direction from the Council on Environmental Quality ("CEQ"). CEQ- the agency tasked with developing the regulations that implement NEPA-published final guidance in 2016 that instructs agencies to consider indirect emissions and emissions from connected actions, including certain types of upstream and downstream emissions, in their NEPA analysis, ${ }^{16}$ and to use programmatic assessments to evaluate the effect of certain decisions (including oil and gas lease authorizations) on climate change. ${ }^{17}$ Consistent with this guidance (and with the draft guidance in place at the time of its announcement), ${ }^{18}$ the Department of the Interior ("DOI") announced in January 2016 that it will conduct a programmatic environmental review of the federal coal leasing program, which will include consideration of greenhouse gas emissions from coal combustion. ${ }^{19}$ Other agencies, such as FERC, have maintained that upstream and down-

13. Del. Riverkeeper Network v. Fed. Energy Regulatory Comm'n, 753 F.3d 1304, 1308-09 (D.C. Cir. 2014).

14. See infra Part IV.B.

15. Some impacts—such as the effect of coal combustion and local air and water quality - may be difficult to evaluate in a manner that is helpful for decision-makers if the precise timing and location of the activity giving rise to those impacts is unknown. But greenhouse gas emissions have global rather than local impacts, and thus an agency can quantify upstream and downstream greenhouse gas emissions without specifying exactly when or where the emissions will occur, and this information is still useful for decision-makers.

16. See Council on Envtl. Quality, Exec. Office of the President, Memorandum for Heads of Federal Departments and Agencies, Final Guidance for Federal Departments and Agencies on Consideration of Greenhouse Gas EmisSions and the Effects of Climate Change in NEPA Review, 13-14, 16 (2016), https://perma.cc/QP7E-7PUM [hereinafter "FINAL CEQ GuIDANCE"].

17. See id. at 31-32.

18. See CEQ Revised Draft Guidance for Federal Departments and Agencies on Consideration of Greenhouse Gas Emissions and the Effects of Climate Change in NEPA Reviews, 79 Fed. Reg. 77,802, 77,826 (Dec. 24, 2014) [hereinafter "Revised Draft CEQ Guidance”].

19. U.S. Dep't of Interior, Order No. 3338, Discretionary Programmatic Environmental Statement to Modernize the Federal Coal Program (2016), https:// perma.cc/LDU5-M3E7. 
stream emissions do not fall within the scope of indirect impacts that must be evaluated under NEPA. ${ }^{20}$

This Article adds to the growing literature on NEPA and climate change analysis and begins to address some of the statutory questions not answered by CEQ's final guidance and the sometimes conflicting decisions in the courts by clarifying when and how agencies should evaluate upstream and downstream greenhouse gas emissions under NEPA. ${ }^{21}$ Part I describes the approval process for fossil fuel extraction and transportation projects, the extent to which agencies have discretion to account for environmental considerations when issuing such approvals, and the contributions these decisions make to global greenhouse gas emissions. Part II outlines the statutory and regulatory requirements of NEPA, focusing in particular on the requirements to evaluate indirect effects and effects of connected actions. Part III describes how various agencies are currently evaluating downstream and upstream emissions in NEPA reviews for fossil fuel-related approvals, one key finding being that there are major inconsistencies in analytical approaches both within and across different agencies. Part IV summarizes and synthesizes the case law involving agencies' obligations to evaluate upstream and downstream emissions in NEPA reviews, and finds that the courts have generally treated such emissions as the type of indirect effects that must be evaluated in a NEPA review.

Finally, Part V offers specific recommendations on the scope of greenhouse gas emissions that should be included in the NEPA analysis for federal approvals related to coal, oil and gas extraction and transportation. While we

20. See, e.g., Order Denying Rehearing, Sabine Pass Liquefaction Expansion, LLC Sabine Pass LNG L.P., Cheniere Creole Trail Pipeline, L.P., 151 FERC 9 61,253, 62,671-73 (June 23, 2015); Bureau of Ocean \& Energy Mgmt., Outer Continental Shelf Oil and Gas Leasing Program: 2012-2017, Final Programmatic Environmental Impact STATEMENT 8-37 (2012).

21. Earlier studies include Aimee Delach et al., Defenders of Wildlife, Reasonably Foreseeable Futures: Climate Change Adaptation and the National Environmental Policy Act (2013); Jessica Wentz et al., Sabin Center for Climate Change Law, Survey of Climate Change Considerations in Federal Environmental Impact Statements, 2012-2014 (2016); Patrick Woolsey, Sabin Center for Climate Change Law, Consideration of Climate Change in Federal EiSs, 2009-2011 (2012); Michael Gerrard, Climate Change and the Environmental Impact Review Process, 22 Nat. Res. \& Env'T. 20 (2008); Madeline June Kass, A NEPA Climate Paradox: Taking Greenhouse Gases into Account in Threshold Significance Determinations, 42 IND. L. REv. 47 (2009); Sarah E. Light, NEPA's Footprint: Information Disclosure as a Quasi-Carbon Tax on Agencies, 87 Tul. L. Rev. 511 (2013); Amy Stein, Climate Change Under NEPA: Avoiding Cursory Consideration of Greenhouse Gases, 81 U. Colo. L. Rev. 473 (2010); Lauren Giles Wishnie, NEPA for a New Century: Climate Change and the Reform of the National Environmental Policy Act, 16 N.Y.U. EnVTL. L.J. 628 (2008). For an examination of how climate change may factor into environmental reviews conducted under the states' "baby NEPAs," see Dave Owen, Climate Change and Environmental Assessment Law, 33 Colum. J. Envtl. L. 57 (2008). 
make a number of recommendations, the core one is that agencies can and should improve the quality of information feeding into their decision-making and public knowledge by incorporating projections of upstream and downstream greenhouse gas emissions into environmental reviews of fossil fuel programs, projects and related management decisions, and that they should do so at the point in time where the information can be most useful-usually, this will be at the programmatic planning stage. Regarding the "proper scope" of upstream and downstream emissions to be considered: we recommend that agencies conduct a lifecycle analysis of greenhouse gas emissions from the production, transportation, processing, and end-use of fossil fuels that will be produced or transported as a result of the proposed action and all reasonable alternatives, and use this as a basis for comparing those alternatives. ${ }^{22} \mathrm{We}$ also recommend that agencies exercise caution when attempting to calculate emissions under the "no action" alternative-that is, the emissions that would be generated from the production and use of alternative energy sources in the absence of the proposed action-for the purpose of estimating the net impact of the proposal on greenhouse gas emissions. In particular, we urge agencies to disclose all data inputs, assumptions, and calculations used in the net emissions analysis, and to ensure that the analysis is accompanied by an inventory of gross lifecycle emissions. Finally, we recommend that the federal government establish uniform procedures for conducting the upstream and downstream emissions analysis.

Our goal is to describe how the federal government could adopt a more consistent approach to environmental reviews that would improve the quality of federal decision-making, improve agencies' chances in litigation, and provide much-needed information about the aggregate effects of fossil fuel development on greenhouse gas emissions and climate change. The federal government could use this information to make more prudent decisions about lease terms, royalties, tax breaks, and public investments in fossil fuel infrastructure, and to develop a long-term plan for phasing out fossil fuel production and consumption in the United States, consistent with our international commitments on climate change.

\section{Federal Decision-Making, Fossil Fuel Development and Greenhouse Gas Emissions}

This Part provides a brief background on the statutory structure for federal leases and approvals for fossil fuel production, processing and transportation infrastructure, and the contributions these decisions make to global greenhouse

22. Table A-3 in the Appendix contains a list of data resources and models that can be used to conduct this analysis in the context of any proposal involving the extraction or transportation of coal, oil, or gas. 
gas emissions. The review makes plain that agencies are well-positioned to conduct meaningful analyses of emissions during their decision-making processes, but by and large have not done so, leaving behind an information gap that needs to be filled.

\section{A. Federal Authority over the Extraction of Fossil Fuels from Federal Lands}

The federal government owns a considerable share of the coal, oil, and gas reserves in the country. In 2014, sales of fossil fuels produced on federal lands totaled 15,975 trillion Btu, almost one quarter of U.S. total sales. These included 402 million short tons of coal (40.8\% of U.S. total sales), 651 million barrels of crude oil and lease condensate (21.4\%), 3,551 billion cubic feet of natural gas (14.1\%), and 117 million barrels of natural gas plant liquids (11.3\%). ${ }^{23}$ The Bureau of Land Management ("BLM"), located within DOI, oversees oil, natural gas, and coal leasing and production on federal lands. The U.S. Forest Service ("USFS"), located within the Department of Agriculture, oversees fossil fuel production on National Forest Service ("NFS") lands in conjunction with BLM. USFS determines whether NFS lands will be open for fossil fuel development and whether such development will be subject to constraint. ${ }^{24} \mathrm{BOEM}$, also housed within DOI, oversees offshore oil and gas leasing and production. ${ }^{25}$

The Mineral Leasing Act grants broad discretion to these agencies to decide how and whether to lease federal lands for fossil fuel development. ${ }^{26}$ The Act does not specifically require that any federal lands be made available for fossil fuel production. Rather, it provides that the Secretary of Interior may lease lands for fossil fuel production if certain criteria related to the public interest are met. ${ }^{27}$ Although the Act does specify that, with respect to oil and gas

23. U.S. Energy Info. Admin., Sales of Fossil Fuels Produced from Federal and Indian Lands FY 2003 Through FY 2014 (2015).

24. For more information about federal oversight of fossil fuel development on federal lands, see Adam Vann, Cong. Research Serv., Energy Projects on Federal Lands: Leasing AND Authorization (2012).

25. For more information about federal oversight of offshore oil and gas development, see Adam Vann, Cong. Research Serv., Offshore Oil and Gas Development: LeGAL FrameWORK (2013).

26. See 30 U.S.C. $§ 226(a)$ (2012) (“[Lands] known or believed to contain oil or gas deposits may be leased by the secretary.”); 30 U.S.C. § 201 (“The Secretary . . is authorized to divide any lands subject to this chapter which have been classified for coal leasing into leasing tracts of such size as he finds appropriate and in the public interest and which will permit the mining of all coal which can be economically extracted in such tract and thereafter he shall, in his discretion, upon the request of any qualified applicant or on his own motion, from time to time, offer such lands for leasing and shall award leases thereon by competitive bidding.").

27. See 30 U.S.C. $§ 192$ (2012) (specifying that the Secretary may reject bids for oil and gas that are paid as royalty to the United States if accepting the offer would not serve the public 
reserves, "[1]ease sales shall be held for each State where eligible lands are available at least quarterly and more frequently if the Secretary of the Interior determines such sales are necessary," it does not contain a mandate that lands be designated as "eligible" for leasing. ${ }^{28}$ This provision can thus be interpreted as affording discretion over whether any leases are offered for sale. The courts have not yet had the opportunity to elaborate on the federal government's discretion under this particular provision of the Minerals Leasing Act (which was added in 1987), ${ }^{29}$ but they have held that the other provisions of the Act merely authorize and do not require the issuance of any oil or gas leases. ${ }^{30}$

On at least four occasions, the federal government has issued a moratorium on such leases. First, in the late 1920s, when crude oil prices were plummeting, President Hoover ordered DOI to cease all oil leasing. The Supreme Court upheld the moratorium, noting that the statute "goes no further than to empower the Secretary to execute leases which, exercising a reasonable discretion, he may think would promote the public welfare."31 More recently, DOI has issued three moratoriums on federal coal leasing while conducting environ-

interest); 30 U.S.C. $§ 201$ (The Secretary "is authorized to divide any lands . . which have been classified for coal leasing into leasing tracts of such size as he finds appropriate and in the public interest ... and thereafter he shall, in his discretion, upon the request of any qualified applicant or on his own motion, from time to time, offer such lands for leasing and shall award leases thereon by competitive bidding."); 30 U.S.C. § 205 (Secretary may authorize consolidation of leases if it is in the public interest); 30 U.S.C. $§ 208$ (Secretary may authorize individuals or associations of individuals to take coal from public lands without payment if it will "safeguard the public interests"); 30 U.S.C. § 226(a) ("[Lands] which are known or believed to contain oil or gas deposits may be leased by the Secretary.") (emphasis added); 30 U.S.C. $§ 226(\mathrm{~m})$ (Secretary may alter cooperative oil and gas leases, so long as he has consent from lessees and the modifications are "necessary or proper to secure the proper protection of the public interest").

28. 30 U.S.C. $\S 226(\mathrm{~b})$.

29. One district court may soon have such an opportunity, as a lawsuit on this issue is currently pending in the District of New Mexico. See Complaint, W. Energy All. v. Jewell, Case No. 1:16-cv-00912 (D.N.M., Aug. 1, 2016). In addition, a petition has been filed with DOI seeking a moratorium on all fossil fuel leases on public lands. See Ctr. for Biological Diversity, Petition for a Moratorium on the Leasing of Federal Public Land Fossil Fuels Under the Mineral Leasing Act, 30 U.S.C. §§ 226, 241 (July 12, 2016), https://perma.cc/N3XYTNKL.

30. See Udall v. Tallman, 380 U.S. 1, 4 (1965) (noting that the Minerals Leasing Act "left the Secretary [of Interior] discretion to refuse to issue any [oil or gas] lease at all on a given tract"); United States ex rel. McLennan v. Wilbur, 283 U.S. 414, 419 (1931) (holding that the Secretary of Interior could not be compelled to issue oil and gas leases on public land, since issuance thereof was within his discretion); see also Dunn v. Ickes, 115 F.2d 36 (D.C. Cir. 1940); Geosearch, Inc. v. Andrus, 508 F. Supp. 839, 842 (D. Wyo. 1981); United States ex rel. Jordan v. Ickes, 55 F. Supp. 875 (D.D.C. 1943), affd, 143 F.2d 152 (D.C. Cir. 1944).

31. Wilbur, 283 U.S. at 419. 
mental reviews of the program..$^{32}$ The most recent moratorium began in January 2016, when DOI announced a three-year moratorium on federal coal leasing, pending a reevaluation of the leasing program's environmental, social, and economic effects. ${ }^{33}$

\section{B. Federal Authority Over the Transportation and Processing of Fossil Fuels}

The federal government also has considerable oversight over the construction of infrastructure that is used to process and transport fossil fuels to domestic and international markets. As a starting point, the Department of Energy's ("DOE") authorization is required prior to the import or export of natural gas to or from a non-free trade agreement country. ${ }^{34}$ FERC has exclusive authority over the siting, construction and operation of interstate natural gas pipelines, liquefied natural gas ("LNG") export terminals, and associated infrastructure, such as liquefaction facilities. ${ }^{35}$ Similarly, the Surface Transportation Board ("STB") has exclusive licensing authority for the construction and operation of rail lines, which provide the primary mode of transport for coal. ${ }^{36}$ The federal government does not have equivalent authority over the construction of oil pipelines. However, these projects may nonetheless require federal approvals that trigger the environmental review process under NEPA. For example, a Presidential Permit is required for pipelines and other infrastructure used for the exportation or importation of petroleum and petroleum products; ${ }^{37}$ a Clean Water Act Section 404 permit is required for any project that involves the discharge of dredged and/or fill materials into navigable waters, tributaries, and

32. DOI issued a moratorium on the issuance of new federal coal leases from 1973-1981 in order to prepare a programmatic EIS ("PEIS") for the program, and a subsequent moratorium from 1983-1987 to prepare a PEIS supplement. U.S. DEP'T OF INTERIOR, Q\&A: Department of the Interior Federal Coal Reforms 5 (2015), https://perma.cc/ W9MV-5CGT.

33. U.S. Dep't of Interior, Order No. 3338, Discretionary Programmatic Environmental Statement to Modernize the Federal Coal Program (2016), https:// perma.cc/LDU5-M3E7.

34. 15 U.S.C. $\S 717 b(a)$ (2012) (granting the Federal Power Commission authority to approve or deny natural gas exports); 42 U.S.C. $§ 7172$ (f) (2012) (clarifying that the functions of the Federal Power Commission that were delegated to FERC do not include any function "which regulates the exports or imports of natural gas or electricity" unless the Secretary of Energy assigns such a function to FERC).

35. 15 U.S.C. $\S 717 \mathrm{~b}(\mathrm{e})$ (granting FERC "exclusive authority to approve or deny an application for the siting, construction, expansion, or operation of an LNG terminal"); 15 U.S.C. $\S 717 \mathrm{f}(\mathrm{c})$ (prohibiting the construction and operation of interstate natural gas pipelines and associated infrastructure without FERC authorization).

36. 49 U.S.C. § 10901(a) (2012).

37. See Adam Vann \& Paul W. Parfomak, Cong. Research Serv., R43261, Presidential Permits for Border Crossing Energy Facilities 1-3 (2013); Exec. Order No. 13,337, 3 C.F.R. $\S 165$ (2005); Exec. Order No. 11,423, 3 C.F.R. $§ 742$ (1968). 
adjacent wetlands; ${ }^{38}$ and a Rivers and Harbors Act Section 10 permit is required for projects that involve construction and/or dredge and fill activities in the navigable waters of the United States. ${ }^{39}$

Before approving any proposal to construct interstate natural gas infrastructure, LNG terminals, or rail lines, the responsible agency must issue a "certificate of public convenience and necessity" for the project. ${ }^{40}$ To authorize natural gas exports to countries with which the United States does not have a free trade agreement ("FTA"), DOE must also make a separate finding that such exports will be in the public interest (for countries with FTA status, exports are automatically deemed to be in the public interest). ${ }^{41}$ With respect to natural gas approvals, the Supreme Court has held that FERC must evaluate "all factors bearing on the public interest" before issuing a certificate of public convenience and necessity. ${ }^{42}$ With respect to railroad approvals, the Supreme Court has noted that the purpose of the certificate of public convenience and necessity is to protect the public interest, ${ }^{43}$ and that STB should consider the "infinite variety of circumstances which may occur in specific instances" when issuing such a certificate. ${ }^{44}$ Although the Supreme Court has not yet issued a similar opinion regarding the scope of the public interest review for DOE's approval of natural gas exports, DOE has explicitly recognized that "environmental factors" fall within the scope of its public interest review for export authorizations. ${ }^{45}$ The State Department has similarly broad discretion to consider a variety of public interest factors when issuing Presidential Permits for oil pipelines or other infrastructure intended to export or import oil. ${ }^{46}$ In all cases, it is clear that the agencies have discretion to consider environmental effects when deciding whether the proposed action would serve the public interest, and may even condition their approvals on the implementation of measures to mitigate foreseeable environmental harms. ${ }^{47}$

38. 33 U.S.C. $§ 1344$ (2012).

39. 33 U.S.C. $\S 403$ (2012).

40. 15 U.S.C. $\S 717 f(c)$ (natural gas infrastructure); 49 U.S.C. $§ 10901(a)$ (railways).

41. 15 U.S.C. $\S 717 \mathrm{~b}$.

42. Fed. Power Comm'n v. Transcon. Gas Pipe Line Corp., 365 U.S. 1, 8 (1961) (quoting Atl. Refining Co. v. Pub. Serv. Comm'n, 360 U.S. 378, 391 (1959)).

43. See Chesapeake \& Ohio Ry. Co. v. United States, 283 U.S. 35, 42 (1931).

44. Interstate Commerce Comm'n v. Parker, 326 U.S. 60, 65 (1945).

45. See, e.g., U.S. Dep't of Energy, DOE/FE Order No. 3784, Order Granting Blanket Authorization to Export Liquefied Natural Gas By Vessel from the Kenai LNG Facility near Kenai, Alaska, and Vacating Prior Export Authorization 3 (2016).

46. See Exec. Order No. 13,337, 3 C.F.R. § 1(g) (2004) (authorizing the Secretary to issue a Presidential Permit if such authorization will "serve the national interest"); see also ADAM Vann \& Paul W. Parfomak, Cong. Research Serv., Presidential Permits for Border Crossing Energy Facilities (2013).

47. See, e.g., Minisink Residents for Envtl. Pres. \& Safety v. Fed. Energy Regulatory Comm'n, 762 F.3d 97 (D.C. Cir. 2014) (concluding that FERC satisfied its obligation to consider 
Finally, although the Rivers and Harbors Act and the Clean Water Act do not explicitly require the U.S. Army Corps of Engineers ("Corps") to consider the "public interest" when issuing permits under Section 404 and Section 10, the Corps has issued regulations requiring a determination that the proposed structure or work is in the public interest prior to the issuance of any Department of Army ("DA") permits. ${ }^{48}$ The regulations direct the Corps to consider "[a]11 factors which may be relevant to the proposal" including "general environmental concerns," "fish and wildlife values," "energy needs," and "in general, the needs and welfare of the people." ${ }^{49}$ Federal courts have upheld the Corps' authority to consider these factors when deciding whether to issue permits under Section 10 and Section 404. ${ }^{50}$ However, because the nature of the Corps' approval in this context is more limited in scope than, for example, the approval of an entire pipeline, courts have also held that the NEPA review does not necessarily need to encompass all of the indirect effects of the broader project for which the permit is required. ${ }^{51}$ The proper scope of the NEPA review for

alternatives in granting a certificate of public convenience and necessity for construction of a natural gas compressor station); N. Plains Res. Council, Inc. v. Surface Transp. Bd., 668 F.3d 1067, 1095 (9th Cir. 2011) (declaring that STB appropriately relied on environmental documents when making its public convenience and necessity determination); Midcoast Interstate Transmission, Inc. v. Fed. Energy Regulatory Comm'n, 198 F.3d 960 (D.C. Cir. 2000) (also concluding that FERC satisfied its obligation to consider alternatives in granting a certificate of public convenience and necessity for construction of interstate natural gas pipeline).

48. See 33 C.F.R. § 320.4(a)(1) (2016).

49. Id.

50. See, e.g., Town of Norfolk v. U.S. Army Corps of Eng'rs, 968 F.2d 1438, 1454 (1st Cir. 1992) (recognizing the Corps' authority to conduct a "general balancing of a number of economic and environmental factors" when considering whether to issue a Section 404 permit); Zabel v. Tabb, 430 F.2d 199, 199 (5th Cir. 1970) (permitting the Corps to refuse to issue a Section 10 permit based on ecological impacts even though the project will not interfere with navigation, flood control, or power production); United States v. Lewis, 355 F. Supp. 1132 (S.D. Ga. 1973) (reinforcing that applications for Section 10 permits must be evaluated based on environmental impacts as well as navigational considerations).

51. See, e.g., Kentuckians for the Commonwealth v. U.S. Army Corps of Eng'rs, 746 F.3d 698, 707 (6th Cir. 2014) (upholding the Corps' decision to ignore the effects of surface coal mining in an Environmental Assessment ("EA") for a Section 404 permit authorizing dredge and fill activities for a proposed surface coal mining operation); Ohio Valley Envtl. Coal. v. Aracoma Coal Co., 556 F.3d 177, 195 (4th Cir. 2009) (upholding the Corps' decision to ignore the broader effects related to mountaintop removal coal mining in four EAs for Section 404 permits authorizing dredge and fill activities related to mountaintop removal); Wetlands Action Network v. U.S. Army Corps of Eng'rs, 222 F.3d 1105 (9th Cir. 2000), abrogated on other grounds by Wilderness Soc'y V. U.S. Forest Serv., 630 F.3d 1173 (9th Cir. 2011) (upholding the Corps' decision to ignore the effects of a development project in EAs for Section 404 permit authorizing the fill of wetlands for the development project); Water Works \& Sewer Bd. of the City of Birmingham v. U.S. Army Corps of Eng'rs, 983 F. Supp. 1052, 1076 (N.D. Ala. 1997) (upholding Corps' decision to ignore environmental effects of entire water supply project in EA for Section 404 and Section 10 permits required 
these types of approvals is a complicated subject that has been covered by other authors,,$^{52}$ and is beyond the purview of this paper. Instead, we will focus on those circumstances where the entire action is subject to federal authority, as is the case for approvals of pipelines, exports, and fossil fuel production leases.

\section{Greenhouse Gas Emissions from Fossil Fuels Produced from Federal Lands}

The greenhouse gas emissions from federal leasing approvals and other decisions affecting the production of fossil fuels from federal lands can be divided into two categories: (1) direct emissions associated with the production of those fuels, and (2) indirect or "downstream" emissions that occur as a result of the transportation, processing and end use of those fuels. The first categorydirect emissions-are typically discussed in environmental review documents, although the quality and scope of the analysis varies substantially. ${ }^{53}$ The Environmental Protection Agency's ("EPA") Inventory of U.S. Greenhouse Gas Emissions and Sinks: 1990-2013 estimates the direct emissions in 2013 from coal mining (64.6 MMT CO $2 \mathrm{e}),{ }^{54}$ natural gas production $\left(62.9 \mathrm{MMT} \mathrm{CO}_{2} \mathrm{e}\right),{ }^{55}$ and oil production (24.7 MMT CO $\mathrm{Ce}_{2 \mathrm{e}}$. ${ }^{56}$ But these figures do not include any combustion-related emissions from equipment and vehicles used in mining and drilling operations. There are some Environmental Impact Statements ("EISs") that include a complete (or nearly complete) inventory of direct emissions for specific proposals, including emissions from equipment, but no official federal estimate of aggregate emissions from all federal leasing activity exists. ${ }^{57}$

Direct emissions from production represent only a small proportion of the life cycle emissions from the fossil fuels that are produced as a result of the public land leases. Unfortunately, it is difficult to say exactly how much of a

for construction of water intake structure and associated pipeline), affd sub nom. Water Works v. U.S. Army Corps Eng'rs, 162 F.3d 98 (11th Cir. 1998).

52. For an excellent overview of this topic, see Timothy J. Hagerty, Beyond Section 404: Corps Permitting and the National Environmental Policy Act, 32 EnVTL. L. ReP. 10853 (2002) (discussing the scope of EA Section 404 permits).

53. This was not always the case. The number of EISs that discuss greenhouse gas emissions has increased in the past few years as a result of the CEQ's draft guidance on climate change and NEPA, originally published in 2010 and revised in 2014. See WENTZ ET AL., supra note 21.

54. EPA, Inventory of U.S. Greenhouse Gas Emissions And Sinks: 1990-2013, at 350, Table 3-28 (2015) (this figure only includes direct methane emissions from coal mining).

55. Id. at 3-70 to 3-71, Tables 3-44 and 3-47 (production emissions include $47.0 \mathrm{MMT} \mathrm{CO}_{2} \mathrm{e}$ of $\mathrm{CH}_{4}$ and $15.9 \mathrm{MMT} \mathrm{CO}_{2}$ ).

56. Id. at 3-58 to 3-59, Tables 3-36 and 3-38 (production emissions include 24.2 $\mathrm{MMT} \mathrm{CO}_{2} \mathrm{e}$

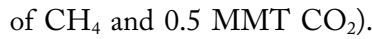

57. See, e.g., U.S. Forest Serv., COC-1362 \& COC-67232, Final Environmental Impact Statement, Federal Coal Lease Modifications COC-1362 \& COC-67232, at 73, 75, 78, 506-07 (2012); Office of Surface Mining, Reclamation \& Enf't, DOI FES 08-49, OSM-EIS-33, Black Mesa Project: Final Environmental ImPACT STATEMENT (2008). 
percentage direct emissions amount to, because as of late 2016 the federal government has not yet published any comprehensive assessment of life-cycle emissions from fossil fuels produced from federal lands. There are a variety of peer-reviewed studies and government reports that evaluate the life-cycle emissions associated with coal, oil, and gas more generally. ${ }^{58}$ These typically provide estimates of life-cycle emissions per unit of electricity generated, as well as details about how life-cycle emissions differ between fuel sources and which stages (production, processing, transport, etc.) are responsible for what proportion of total emissions. ${ }^{59}$ But they do not examine the aggregate impacts of fossil fuels produced from federal lands.

DOI's announcement of its plans to conduct a programmatic review of environmental effects from federal coal leasing, which will include an evaluation of greenhouse gas emissions from coal production and consumption, ${ }^{60}$ and to develop a "public database to account for the annual carbon emissions from fossil fuels developed on federal lands," ${ }^{1}$ should go a long way toward providing a more complete picture of how federal decisions about fossil fuel development can affect global climate change. But the federal government has not yet announced any plans to conduct a similar assessment of oil and gas extraction.

At the same time, there are several environmental groups that have prepared independent studies to evaluate the carbon footprint of federal leasing decisions. According to one study commissioned by the Wilderness Society, the combustion of fossil fuels extracted from federal lands and waters by private leaseholders in 2012 resulted in 1,344 $\mathrm{MMT} \mathrm{CO}_{2} \mathrm{e} .{ }^{62}$ This is equivalent to approximately $21 \%$ of total U.S. greenhouse gas emissions and $24 \%$ of energyrelated emissions. The Center for Biological Diversity commissioned a separate study on the impact of allowing additional exploitation of fossil fuels on federal lands. ${ }^{63}$ The study concluded that if all of the available fossil fuels (leased and unleased) were extracted and used, the lifecycle greenhouse gas emissions (including production, transport, processing and combustion) would be as much as

58. For a list of such studies, see infra Appendix, Table A3.

59. See, e.g., Richard K. Lattanzio, Cong. Research Serv., Life-Cycle Greenhouse Gas Assessment of Coal and Natural Gas in the Power Sector (2015).

60. U.S. Dep't of Interior, Order No. 3338, Discretionary Programmatic Environmental Statement to Modernize the Federal Coal Program (2016).

61. U.S. Dep't of Interior, Fact Sheet: Modernizing the Federal Coal Program 3 (2016).

62. See Stratus Consulting, Greenhouse Gas Emissions from fossil Energy Extracted from Federal Lands and Waters: An Update 13 (2015); see also Claire Moser et al., Ctr. for American Progress \& the Wilderness Soc'y, Cutting Greenhouse Gas from Fossil-Fuel Extraction on Federal Lands and Waters (2015) (discussing these results and the policy implications).

63. See Dustin Mulvaney et al., EcoShift Consulting, The Potential Greenhouse Gas Emissions from U.S. Federal Fossil Fuels (2015). 
492 gigatons (Gt) (492,000 MMT) $\mathrm{CO}_{2} \mathrm{e}^{64}$ Fortunately, 91\% of these fossil fuels (approximately $450 \mathrm{Gt} \mathrm{CO}_{2} \mathrm{e}$ ) have not yet been leased to private industry for extraction. ${ }^{65}$ Greenpeace also published a study of the federal coal program which examined both the downstream greenhouse gas impacts and the corresponding social costs of those emissions. ${ }^{66}$ The study concluded that the carbon pollution from publicly owned coal leased during the Obama administration will cause damages ranging from $\$ 52$ billion to $\$ 530$ billion, using the federal government's social cost of carbon estimates ${ }^{67}$ In contrast, the total amount of revenue generated from those coal lease sales was $\$ 2.3$ billion. ${ }^{68}$ Finally, the Stockholm Environment Institute recently published a study finding that if the federal government stopped issuing new leases and renewing existing leases for fossil fuel extraction on federal lands and waters, this would reduce global $\mathrm{CO}_{2}$ emissions by 100 MMT per year by 2030 and by greater amounts thereafter. ${ }^{69}$ These studies indicate that the overall carbon footprint of fossil fuels produced from federal lands is substantial and that leasing these resources may seriously undermine the nation's ability to meet its greenhouse gas mitigation targets. ${ }^{70}$

\section{Greenhouse Gas Emissions from Transportation and Processing Infrastructure}

As with extraction, there are direct emissions associated with the construction and operation of pipelines, railways, export terminals, liquefaction facilities, and other infrastructure used to process and transport fossil fuels. While there is no comprehensive estimate of direct and indirect emissions from the development of this infrastructure, it is clear that the total carbon impact is significant. According to EPA's inventory, the transportation and processing of

64. Id. at 3 .

65. Id.

66. See Greenpeace, Leasing Coal, Fueling Climate Change: How the Federal Coal Leasing Program Undermines President Obama's Climate Plan (2014).

67. Id. at 2 .

68. Id.

69. See Peter Erickson \& Michael Lazarus, How Would Phasing Out U.S. Federal Leases for Fossil Fuel Extraction Affect $\mathrm{CO}_{2}$ Emissions and $2^{\circ} \mathrm{C}$ Goals? 26 (Stockholm Env't Inst., Working Paper No. 2016-02, 2016).

70. The United States submitted an intended nationally determined contribution ("INDC") to the United Nations Framework Convention on Climate Change Secretariat pledging to reduce nationwide greenhouse gas emissions by $26-28 \%$ below 2005 levels by 2025 . This will

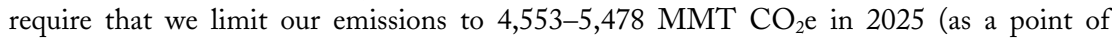
comparison, U.S. greenhouse gas emissions totaled 6,870 $\mathrm{MMT} \mathrm{CO}_{2} \mathrm{e}$ in 2014, representing a $1 \%$ increase over 2013 levels). We are not currently on track to meet the INDC target even with the implementation of current and planned actions for greenhouse gas emission reductions. See EPA, Inventory of U.S. Greenhouse Gas Emissions and Sinks 1990-2014 (2016); Jeffrey B. Greenblatt \& Max Wei, Assessment of the Climate Commitments and Additional Mitigation Policies of the United States, Nature Climate Change (2016). 
natural gas generated at least $180 \mathrm{MMT} \mathrm{CO}_{2 \mathrm{e}}$ in $2013,{ }^{71}$ whereas the transportation and processing of crude oil produced only 6.5 MMT $\mathrm{CO}_{2 \mathrm{e}}$ in 2013 (these include direct emissions from the operation of pipelines and processing facilities). ${ }^{72}$ Notably, neither of these figures include emissions from the construction of transportation and processing infrastructure or from the combustion of fossil fuels used to power natural gas processing facilities and crude oil refineries, because the inventory did not contain data on those emissions.

The development of infrastructure intended to transport and process fossil fuels also affects fossil fuel prices, patterns of production and consumption, and the corresponding emissions that are generated as a result of increased (or prolonged) fossil fuel use. Although there are few studies on the incremental effect of pipelines and other transportation infrastructure on fossil fuel markets and consumption, the government has recently begun to evaluate these questionsprimarily in the context of LNG export terminals.

In 2012, the U.S. Energy Information Administration ("EIA") conducted a study to determine the effect of increased natural gas exports on domestic energy markets. ${ }^{73}$ The study concluded that: (i) an increase in natural gas exports will lead to an increase in natural gas prices, (ii) $60-70 \%$ of the increase in natural gas exports will be met through an increase in domestic natural gas production, and the remaining $30-40 \%$ will be supplied by natural gas that would have been consumed domestically if not for higher prices, and (iii) as natural gas prices increase, the electric power sector will primarily shift to coalfired generation. The study did not contemplate how these market shifts would affect emissions.

In 2014, DOE published an addendum to environmental review documents for LNG export facilities. ${ }^{74}$ The addendum included an assessment of greenhouse gas emissions from the upstream natural gas industry, which ex-

71. This figure includes $\mathrm{CO}_{2}$ emissions and $\mathrm{CH}_{4}$ emissions. This figure does not include any $\mathrm{N}_{2} \mathrm{O}$ emissions (since these were not specified in the EPA inventory). Specific sources include: 47.7 MMT $\mathrm{CO}_{2} \mathrm{e}\left(\mathrm{CO}_{2}\right.$ emissions from natural gas-powered pipelines transporting natural gas), 22.7 MMT $\mathrm{CO}_{2} \mathrm{e}\left(\mathrm{CH}_{4}\right.$ emissions from natural gas processing), 54.4 MMT $\mathrm{CO}_{2} \mathrm{e}\left(\mathrm{CH}_{4}\right.$ emissions from natural gas transmission and storage), $33.3 \mathrm{MMT} \mathrm{CO}_{2} \mathrm{e}\left(\mathrm{CH}_{4}\right.$ emissions from distribution), 21.8 $\mathrm{MMT} \mathrm{CO}_{2} \mathrm{e}$ (non-combustion $\mathrm{CO}_{2}$ emissions from natural gas processing), $0.1 \mathrm{MMT} \mathrm{CO}_{2} \mathrm{e}$ (non-combustion $\mathrm{CO}_{2}$ emissions from natural gas transmission and storage). See EPA, Inventory of U.S. Greenhouse Gas Emissions AND SinKs: 1990-2013, supra note 54, at 2-29, 3-70 to 3-71.

72. The sources of emissions include: $0.2 \mathrm{MMT} \mathrm{CO}_{2} \mathrm{e}\left(\mathrm{CH}_{4}\right.$ from crude oil transportation), 0.8 MMT $\mathrm{CO}_{2} \mathrm{e}\left(\mathrm{CH}_{4}\right.$ from crude oil refining), 5.5 $\mathrm{MMT} \mathrm{CO}_{2} \mathrm{e}\left(\mathrm{CO}_{2}\right.$ from crude refining), 0.1 MMT $\mathrm{CO}_{2} \mathrm{e}\left(\mathrm{CH}_{4}\right.$ from industrial wastewater produced by petroleum refining). Id. at 3-58 to $3-59,7-17$.

73. U.S. Energy Info. Admin., Effect of Increased Natural Gas Exports on DoMESTIC ENERGY MARKETS (2012).

74. U.S. Dep’t of Energy, Addendum to Environmental Review Documents ConCerning Exports of Natural Gas from the United States (2014). 
amined how the increase in natural gas production associated with the increase in exports would affect various aspects of the environment. With respect to climate change the study concluded that each incremental increase in natural gas production of 1 trillion standard cubic feet per year will generate an additional 6.8 million metric tons of $\mathrm{CO}_{2 \mathrm{e}}$ per year. ${ }^{75}$ This is roughly equivalent to the annual greenhouse gas emissions from 1.43 million passenger vehicles or electricity use in 935,000 homes. $^{76}$

That same year, DOE also conducted a comparative study of life-cycle greenhouse gas emissions from LNG exports to European and Asian markets, as compared with coal produced and consumed within those regions, and concluded that the use of U.S. LNG exports will not increase emissions so long as the $L N G$ replaces regional coal. ${ }^{77}$ Specifically, the study concluded that life-cycle greenhouse gas emissions would be $787 \mathrm{~kg} \mathrm{CO} 2 \mathrm{e} / \mathrm{MWh}$ for LNG exports to Europe, and $824 \mathrm{~kg} \mathrm{CO} \mathrm{CO}_{2} \mathrm{e} \mathrm{MWh}$ for LNG exports to Asia (using a 20-year GWP). In contrast, the lifecycle emissions from burning coal in both regions would be $1,095 \mathrm{~kg} \mathrm{CO}_{2} \mathrm{e} / \mathrm{MWh}^{78}$ The study does not evaluate how the lifecycle emissions from U.S. LNG exports compare with emissions of other fuel sources, nor does it include a market analysis to verify whether U.S. LNG exports would in fact replace coal. The agency's conclusion is thus based on an incomplete analysis of alternatives to LNG exports. That said, the life-cycle analysis could be used as a basis for future comparisons of LNG exports and alternatives (including renewables and energy efficiency).

In sum: although the federal government has not yet conducted a comprehensive assessment of the greenhouse gas emissions that can be traced back to fossil fuel leasing decisions and infrastructure approvals, it is clear that these decisions have a significant carbon footprint and analytical tools are available to evaluate that impact. As discussed below, the NEPA review process can and should be used to conduct such assessments both on the project and programmatic level.

75. Id. at 44 .

76. Greenhouse Gas Equivalencies Calculator, EPA (March 10, 2016), https://perma.cc/ECH8X72D. As an additional point of reference, the total export capacity of LNG export terminals that have already been approved by FERC is approximately 4.2 tcf/year, and the total capacity of proposed terminals is 10.9 tcf/year. North American LNG Export Terminals Proposed as of January 6, 2016, Fed. Energy Regulatory Comm'n (Mar. 10, 2016) https://perma.cc/B47R-JCMN; North American LNG Import/Export Terminals Approved as of January 6, 2016, Fed. Energy Regulatory Comm'n (Mar. 10, 2016) https:// perma.cc/NZ72-MDA6.

77. U.S. Dep’t of Energy, Life-Cycle Greenhouse Gas Perspective on Exporting Liguefied Natural Gas from the United States (2014).

78. Id. at $9-10$. 


\section{The National Environmental Policy Act: STAtute and Regulations}

\section{A. The National Environmental Policy Act}

NEPA is a statute of famously broad environmental ambition. ${ }^{79}$ It establishes a national policy to "create and maintain" a "productive harmony" between "man and nature" and to "fulfill" the obligations imposed by the principle of intergenerational equity, among other things. ${ }^{80}$ The statute further requires the federal government-again, among other things_- to "improve and coordinate" its activities in order to better serve as a "trustee of the environment;" to assure "safe, healthful, productive, and esthetically and culturally pleasing surroundings;" to protect against "undesirable and unintended consequences;" and to preserve historic, cultural and natural resources. ${ }^{81}$

The process of environmental impact review is the mechanism through which the statute seeks to deliver on these goals. Section 102(2)(C) of NEPA requires all federal agencies to prepare a "detailed statement" on the environmental impacts of proposals for legislation and major federal actions significantly affecting the quality of the human environment. ${ }^{82}$ This Environmental Impact Statement ("EIS") must discuss: (i) the environmental impact of the proposed action, (ii) any adverse environmental effects which cannot be avoided should the proposal be implemented, (iii) alternatives to the proposed action, (iv) the relationship between local short-term uses of man's environment and the maintenance and enhancement of long-term productivity, and (v) any irreversible and irretrievable commitments of resources which would be involved in the proposed action should it be implemented. ${ }^{83}$

In addition to the core EIS requirements, there are other less frequently discussed requirements that are also relevant to an agency's decisions about how to handle fossil fuel-related plans and approvals. Section 102(2)(E) requires an alternatives analysis for "any proposal which involves unresolved conflicts concerning alternative uses of available resources." ${ }^{84}$ Section 102(2)(F) requires federal agencies to take a global view of environmental problems, and, "where

79. See, e.g., Bradley Karkkainen, Toward a Smarter NEPA: Monitoring and Managing Government's Environmental Performance, 102 Colum. L. Rev. 903, 909-16 (2002); Jonathan Poisner, A Civic Republican Perspective on the National Environmental Policy Act's Process for Citizen Participation, 26 EnvTl. L. 53, 54-55 (1996); Sidney A. Shapiro, Administrative Law After the Counter-Reformation: Restoring Faith in Pragmatic Government, 48 U. Kan. L. Rev. 689, 693-96 (2000).

80. 42 U.S.C. $\S 4331$ (a) (2012).

81. 42 U.S.C. $\S 4331(\mathrm{~b})$.

82. 42 U.S.C. $\S 4332(2)(C)$.

83. Id.

84. 42 U.S.C. $\S 4332(2)(\mathrm{E})$. 
consistent with the foreign policy of the United States, lend appropriate support to initiatives, resolutions, and programs designed to maximize international cooperation in anticipating and preventing a decline in the quality of mankind's world environment." ${ }^{85}$

\section{B. NEPA Regulations}

CEQ is tasked with issuing regulations to implement NEPA. ${ }^{86}$ Each federal agency also develops its own NEPA procedures to supplement the CEQ regulations. As a result, NEPA procedures vary from agency to agency, though an agency's NEPA procedures must be consistent with the CEQ regulations.

The CEQ regulations define three types of environmental impacts (or "effects") that agencies must consider when conducting NEPA reviews: direct effects, indirect effects, and cumulative effects. Direct effects are "caused by the action and occur at the same time and place." ${ }^{87}$ Indirect effects are "caused by the action and are later in time or farther removed in distance, but are still reasonably foreseeable." ${ }^{88}$ Such effects may include "growth inducing effects related to induced changes in the pattern of land use, population density or growth rate, and related effects on air and water and other natural systems, including ecosystems." ${ }^{89}$ Cumulative effects result from "the incremental impact of the action when added to other past, present, and reasonably foreseeable future actions regardless of what agency (federal or non-federal) or person undertakes such other actions." ${ }^{90}$ As discussed in Part IV, below, most federal courts have interpreted upstream and downstream emissions as indirect effects of fossil fuel extraction and transportation projects.

The CEQ regulations also specify that agencies "shall" consider three types of related actions when deciding on the scope of actions and impacts to

85. 42 U.S.C. $\S 4332(2)(F)$.

86. CEQ's authority to issue regulations under NEPA is based on the duties and functions established for the Council by the statute, as well as two Executive Orders and the text of NEPA. See 42 U.S.C. § 4344(3) (directing CEQ to "review and appraise" federal programs and activities to determine the extent to which they fulfill the statute's stated policy, and to make recommendations to the President with respect thereto); Exec. Order No. 11,514, 35 Fed. Reg. 4248 (Mar. 7, 1970); Exec. Order No. 11,991, 42 Fed. Reg. 26,967 (May 24, 1977). Although NEPA does not expressly state that CEQ shall develop implementing regulations, federal courts have consistently deferred to CEQ's interpretation of NEPA. See, e.g., Robertson v. Methow Valley Citizens Council, 490 U.S. 332, 355 (1989) (CEQ regulations are entitled to "substantial deference"); See also Andrus v. Sierra Club, 442 U.S. 347, 358 (1979).

87. 40 C.F.R. $\S 1508.8(a)(2016)$.

88. 40 C.F.R. $\S 1508.8($ b).

89. Id.

90. 40 C.F.R. $§ 1508.7$. 
evaluate in an EIS. ${ }^{91}$ These include connected actions, which are "closely related and therefore should be discussed in the same impact statements;" ${ }^{92} \mathrm{cu}-$ mulative actions, which "have cumulatively significant impacts and should therefore be discussed in the same impact statement;" 93 and similar actions, which "have similarities that provide a basis for evaluating their environmental consequences together, such as common timing or geography." "The regulations also note that an agency cannot break down an action into "small component parts"-or improperly segment an action-in order to avoid a determination that the action will have a significant effect on the environment. ${ }^{95}$

These categories intersect in a number of ways. First, there is some overlap between the requirement to consider the environmental effects of related actions together and the requirement to evaluate indirect environmental effects. In the NEPA review of a proposed coal mining plan, for example, the greenhouse gas emissions from transporting the coal could be treated as indirect emissions or as emissions from a "connected action," at least where the transportation requires federal approval. Second, the regulations specify that connected and cumulative actions "should" be discussed in the same EIS, and the courts have interpreted these as enforceable requirements. However, for similar actions, the regulations state that agencies "may wish to evaluate these in the same impact statement" and "should do so when the best way to assess adequately the combined impacts of similar actions or reasonable alternative to such actions is to treat them in a single impact statement." ${ }^{" 96}$ Due to the permissive language in this section, courts have granted considerable deference to agency decisions about whether to prepare a single EIS for similar actions. ${ }^{97}$

Of course, sometimes there is just not adequate information about these various types of potentially interconnected activities to meaningfully analyze them together. The CEQ regulations expressly discuss how agencies should handle missing or incomplete information about potentially significant environmental impacts, including indirect impacts. In these circumstances, agencies are required to obtain any missing information that is essential to a reasoned choice among alternatives, unless the costs of obtaining the information are exorbitant

91. 40 C.F.R. $\S 1508.25$.

92. 40 C.F.R. $\S 1508.25(a)(1)$. Connected actions include actions that "automatically trigger" other actions which may require EISs, actions that "cannot or will not proceed unless other actions are taken previously or simultaneously," and actions that are "interdependent parts of a larger action and depend on the larger action for their justification." Id.

93. 40 C.F.R. $\S 1508.25(\mathrm{a})(2)$.

94. 40 C.F.R. $\S 1508.25(\mathrm{a})(3)$.

95. 40 C.F.R. $\S 1508.27(7)$.

96. 40 C.F.R. $\S 1508.25(a)(3)$.

97. See infra Part IV.C.3. 
or the information is simply unavailable..$^{98}$ If an agency cannot obtain the missing information due to exorbitant costs or infeasibility, it must include the following items in the EIS: (i) a statement that such information is incomplete or unviable, (ii) a statement of the relevance of the information, (iii) a summary of existing credible scientific evidence which is relevant to evaluating environmental impacts in the absence of such information, and (iv) the agency's evaluation of such impacts based on theoretical approaches or research methods generally accepted in the scientific community. ${ }^{99}$

\section{Agency Guidance}

The CEQ issued final guidance on climate change and NEPA reviews in August 2016, ${ }^{100}$ after having published an initial draft of the guidance in 2010, and a revised draft in 2014. ${ }^{101}$ (The final guidance, which reflects many years of agency consideration, does not create new legal requirements, but advises the regulated community as to CEQ's understanding of what NEPA requires). The 2010 draft noted that agencies should consider both direct and indirect greenhouse gas emissions, and that the analysis of indirect effects "must be bounded by limits of feasibility in evaluating upstream and downstream effects of Federal agency actions," 102 but did not go into detail about the scope of indirect emissions that should be considered for specific types of projects. ${ }^{103}$ The 2014 revised draft guidance provided more insight on this question, specifying that agencies should account for greenhouse gas emissions from the proposed action and any connected actions, "subject to reasonable limits based on feasibility and practicality." 104 The analysis should include "emissions from activities that have a reasonably close causal relationship to the Federal action, such as those that

98. 40 C.F.R. § 1502.22(a).

99. 40 C.F.R. $§ 1502.22(\mathrm{~b})$.

100. See Final CEQ Guidance, supra note 16. See also Notice of Availability for Final Guidance for Federal Departments and Agencies on Consideration of Greenhouse Gas Emissions and the Effects of Climate Change in NEPA Reviews, 81 Fed. Reg. 51,866 (Aug. 5, 2016).

101. Revised Draft CEQ Guidance, supra note 18.

102. Council on Envtl. Quality, Draft NEPA Guidance on Consideration of the Effects of Climate Change and Greenhouse Gas Emissions 3 (2010).

103. It is also worth noting that the 2010 guidance did not apply to federal "land and resource management actions"-particularly those that entailed changes in land use or land management strategies-because there was no established federal protocol for assessing their effect on carbon release and sequestration at a landscape scale. Although decisions involving fossil fuels could qualify as "resource management actions," the guidance specifically cited coal mining authorizations as one type of project that would be covered by the recommendations for greenhouse gas reporting. Id. at 2 . Whether the original guidance applied to the management of fossil fuels is now a moot question, since the 2014 revised draft guidance explicitly applies to such actions.

104. See Revised Draft CEQ Guidance, supra note 18 , at 77,825-26. 
may occur as a predicate for agency action (often referred to as upstream emissions) and as a consequence of the agency action (often referred to as downstream emissions)." 105

The final guidance contains the same language, except that the words "upstream emissions" and "downstream emissions" have been removed. ${ }^{106}$ To illustrate the scope of analysis for connected actions, the guidance notes that "NEPA reviews for proposed resource extraction and development projects typically include the reasonably foreseeable effects of various phases in the process, such as clearing land for the project, building access roads, extraction, transport, refining, processing, using the resource, disassembly, disposal, and reclamation." 107 It also notes that the indirect effects of a Federal lease sale of coal for energy production would include emissions from the combustion of the coal. ${ }^{108}$ In addition, the guidance directs agencies to a study of life-cycle greenhouse gas emissions from coal and natural gas as an example of the type of resource that should be used to evaluate indirect emissions. ${ }^{109}$

There are other guidance documents which also provide some insight on the scope of greenhouse gas emissions that should be evaluated in NEPA documents for fossil fuel extraction and transportation infrastructure approvals. Although CEQ has not issued a standalone guidance document for indirect effects analysis, ${ }^{110}$ the agency did publish a list of Questions and Answers About the NEPA Regulations that discusses how uncertainties about indirect effects should be addressed:

The EIS must identify all the indirect effects that are known, and make a good faith effort to explain the effects that are not known but are "reasonably foreseeable." (40 CFR §1508.8(b)). In the example, if there is total uncertainty about the identity of future land owners or the nature of future land uses, then of course, the agency is not required to engage in speculation or contemplation about their future

105. Id. at 77,826 .

106. See FinAl CEQ Guidance, supra note 16, at 13 ("Activities that have a reasonably close causal relationship to the Federal action, such as those that may occur as a predicate for a proposed agency action or as a consequence of a proposed agency action, should be accounted for in the NEPA analysis.").

107. Id. at 14 .

108. Id. at 16 n. 42 .

109. See id. at 16, n.43.

110. CEQ did publish guidance on cumulative effects analysis, which clarifies that the appropriate area for the analysis of cumulative impacts should encompass any resources that could be affected by the proposed action. For the evaluation of air quality impacts, the guidance notes that the appropriate geographic area for analysis could be the global atmosphere (presumably if greenhouse gas emissions are released in a meaningful quantity). The guidance does not, however, discuss the proper zone of analysis for indirect impacts. CounCIL ON ENVTL. Quality, Guidance on Cumulative Effects 15 (1997). 
plans. But, in the ordinary course of business, people do make judgments based upon reasonably foreseeable occurrences. It will often be possible to consider the likely purchasers and the development trends in that area or similar areas in recent years; or the likelihood that the land will be used for an energy project, shopping center, subdivision, farm or factory. The agency has the responsibility to make an informed judgment, and to estimate future impacts on that basis, especially if trends are ascertainable or potential purchasers have made themselves known. The agency cannot ignore these uncertain, but probable, effects of its decisions. ${ }^{111}$

Notably, the "growth inducing effects" described in this example would be more difficult to forecast than, for example, downstream greenhouse gas emissions from the combustion of fossil fuels. There is considerable uncertainty about future land uses and development trends, whereas there is a good deal of certainty about the eventual fate of coal, oil, and gas - the vast majority of these resources are combusted, and agencies can use available data on $\mathrm{CO}_{2}$ emission factors for various combustion technologies to provide a reasonable estimate of combustion emissions.

Other agencies have also issued guidance on the meaning of "indirect effects" and what is "reasonably foreseeable." 112 BLM's NEPA Guidebook provides some examples of indirect effects. For example, in a proposal for a rightof-way request from a private company to build a road across BLM-managed land to provide access to a privately owned and operated quarry, the construction and operation of which cannot proceed unless the road is constructed, the agency should evaluate the construction and operation of the quarry as indirect effects of the proposed action. ${ }^{113}$ The guidebook further notes that, where there is no causal link between the BLM decision and the non-federal action (con-

111. Forty Most Asked Questions Concerning CEQ's NEPA Regulations, 46 Fed. Reg. 18,026, 18,031 (March 23, 1981).

112. In addition to the BLM handbook, see Nat'L Cooperative Highway Res. Program, NCHRP Report 466: Desk Reference for Estimating the Indirect Effects of Proposed Transportation Projects 21 (2002) (noting that, for transportation projects, indirect effects include induced growth "attributed to changes in accessibility caused by the project" and that where a project proponent relies on induced growth as a selling point for the project, this "confirms such indirect effects as probable, reasonably foreseeable, and potentially significant”); Fed. Highway Admin., Questions and Answers Regarding the Consideration of Indirect and Cumulative Impacts in the NEPA Process, https://perma.cc/LKS8-TJ6G (indirect impacts are a "subset of cumulative impacts" but are "distinguished by an established cause and effect relationship" to the proposed federal action, and that such events must be "probable" and not merely "possible" in order to be considered reasonably foreseeable).

113. Bureau of Land Mgmt., NePA Handbook 46-47 (2008). 
struction and operation of the quarry), the effects may still need to be analyzed in the cumulative impacts analysis. ${ }^{114}$

The BLM guidebook also discusses the concept of "related actions" including connected, cumulative and similar actions. It notes that related actions that are not subject to NEPA approval may nonetheless need to be considered in the indirect and/or cumulative effects analysis. ${ }^{115}$ It also notes that joint reviews should be conducted for certain types of related actions even if they are undertaken by separate agencies-for example, BLM's decision to construct a trail to provide recreational access to a USFS campground should be evaluated as aspects of a broader proposal, and a joint NEPA review can be conducted by both BLM and USFS. ${ }^{116}$

\section{An Agency-by-Agency Look at the Scope of Existing Federal Analysis of Upstream and Downstream Greenhouse Gas Emissions Under NEPA}

Surveys of federal EISs published from 2009 through 2014 reveal that some federal agencies are beginning to account for upstream and/or downstream emissions in NEPA reviews for fossil fuel-related proposals, in part due to public pressure and judicial intervention. ${ }^{117}$ Others have maintained that such an analysis is not required, because these emissions do not fall within the scope of indirect effects that must be analyzed in NEPA reviews. This trend has continued through 2015 and the beginning of 2016: some agencies have evaluated upstream and/or downstream emissions in some NEPA documents, but they lack a systematic approach for conducting this analysis. This Part provides a brief overview of how different federal agencies have interpreted and implemented their NEPA obligations in this context. Notably, the NEPA documents discussed in this section were published before the CEQ guidance on climate change was finalized. The final guidance, should it remain in place in the new administration, may promote greater uniformity in agency practice-in particular, the fact that CEQ has described emissions from coal combustion as an indirect effect of coal production should put agencies on notice that they should evaluate end-use emissions from fossil fuel consumption as indirect effects of fossil fuel production. ${ }^{118}$ However, the CEQ guidance does not contain similarly explicit directives for other types of upstream and downstream emissions-it merely refers agencies to a life-cycle study of emissions from coal and natural gas as an example of a resource that should be used to evaluate indirect

114. Id. at 47.

115. Id. at $45-47$.

116. Id. at 45 .

117. See Delach et AL., supra note 21; Wentz et Al., supra note 21; WoOlsey Et AL., supra note 21.

118. See Final CEQ Guidance, supra note 16, at 16 n.42. 
emissions. ${ }^{119}$ The other relevant provisions of the guidance reflect existing regulatory mandates (e.g., the guidance directs agencies to account for indirect emissions and emissions from connected actions, but the regulations already require analysis of indirect impacts and impacts from connected actions). Finally, the guidance is not a regulation and thus not legally binding (although it would have persuasive force in court). For these reasons, the actual effect of the guidance on agency practice is difficult to predict.

\section{A. Bureau of Land Management}

BLM frequently acts as the lead agency for NEPA reviews of oil, gas, and coal land allocations, mining plans and lease approvals. Yet, BLM has not developed a consistent methodology for analyzing downstream emissions in these EISs.

Prior to 2010, the agency maintained that downstream emissions-particularly from combustion - need not be evaluated because they will occur regardless of whether the proposed action is implemented. ${ }^{120}$ More recently, BLM has begun to disclose downstream emissions from the combustion of fossil fuels in some EISs. In a 2010 EIS for several coal lease applications, BLM quantified emissions from combustion (which totaled 4,040.5 million tons $\mathrm{CO}_{2} \mathrm{e}$ ), ${ }^{121}$ but concluded that these emissions probably would not differ under the proposed action and the no-action alternative because there were other sources of coal that could be substituted for this source. ${ }^{122}$

BLM has reached a different conclusion about the relationship between the proposal and the no-action alternative in some of its more recent EISs for

119. See id. at 16 n. 43 .

120. See, e.g., Bureau of Land Mgmt., EIS-ES-030-2008-0004, Final Land Use Analysis and Final Environmental Impact Statement for the East Lynn Lake Coal LEASE 266 (2009) ("The use of coal as a national energy source would generate GHG emissions, however the location, combustion efficiency, and amount of GHG emissions potentially generated is beyond the scope of this analysis. Since the Proposed Action would simply extend the life of the Applicants' existing, adjoining operations, it is unlikely total GHG emission would change substantially. The No Action alternative could lower direct GHG emissions from mine transportation and processing equipment minimally, it is likely alternative sources would maintain the use of coal at national levels."); BuREAU OF LAND MGMT., UTU-77114, Final Environmental Impact Statement, Flat Canyon Federal Coal Lease Tract 2-11 (2002) ("If Flat Canyon Tract coal is not mined and burned, coal from other sources with higher potential for producing pollutants would most likely be purchased and burned in these or other plants. The issues of climate changes and global warming from combustion of fossil fuels are considered beyond the scope of this analysis.").

121. Bureau of Land Mgmt., Final Environmental Impact Statement for the Wright Area Coal lease Applications 4-140 (2010).

122. Id. at $4-141$. 
coal, oil, and gas development. ${ }^{123}$ Notably, in a 2015 EIS for a coal lease, BLM expressly acknowledged that "the burning of the coal is an indirect impact that is a reasonable progression of the mining activity"124 and quantified emissions from combustion without any disclaimer about other sources of coal. ${ }^{125}$ In that same EIS, BLM also acknowledged that truck traffic to haul coal would be extended as a result of the proposed lease approval, and that this would generate additional emissions (but it did not quantify these emissions). ${ }^{126}$ And, as noted above, in January 2016 DOI announced that BLM would undertake a comprehensive review of the federal coal leasing program and prepare a programmatic EIS that is anticipated to include an extensive analysis of downstream emissions.

BLM's approach to its assessment of downstream emissions remains inconsistent, however. For example, in two 2015 EISs for oil and gas development, BLM did not even mention let alone quantify emissions from combustion or transportation of the extracted fuels, nor did it explain why those emissions were omitted from the inventory. ${ }^{127}$ BLM has also repeatedly ignored downstream emissions in EAs for an oil and gas lease sales, explaining that it only considers emissions from the production phase "[b]ecause oil and gas leaves the custody and jurisdiction of the BLM after the production phase and before processing or refining." 128

123. See, e.g., Bureau of Land Mgmt., DOI-BLM-UT-C040-2015-0011-EIS, Alton Coal Tract Lease by Application, Supplemental Draft EIS 4-74 (2015) (quantifying emissions without a disclaimer about other sources of coal); BUREAU OF LAND Mgmt., BLM/CO/PL-16/002, Previously Issued Oil and Gas Leases in the White River National Forest, Draft Environmental Impact Statement 4.248, 4.2-59 (2015) (quantifying total emissions estimates including assumed end use energy consumption $\mathrm{CO}_{2}$ emissions); Bureau of Land Mgmt., DeS-11-51, Alton Coal Tract Lease by Application, Draft Environmental Statement 4-31 to 4-32 (2011) (quantifying greenhouse gas emissions from combustion without any disclaimer about these emissions being offset by other sources of coal).

124. Bureau of Land Mgmt., UTU-84102, Final Supplemental Environmental Impact Statement for the Leasing and Underground Mining of the Greens Hollow Federal Coal Lease Tract 287 (2015).

125. See id. at 286 .

126. Id. at 287.

127. See Bureau of Land Mgmt., DOI-BLM-CO-S050-2013-0022-EIS, Draft Environmental Impact Statement for the Bull Mountain Unit Master Development Plan (2015); Bureau of Land Mgmt., Proposed Resource Management Plan amendment and Final Environmental Impact Statement for Oil and Gas DeVELOPMENT (2015).

128. See, e.g., Bureau of Land Mgmt., DOI-BLM-NM-040-2015-61-EA, Environmental Assessment for April 2016 Competitive Oil and Gas Lease Sale 52 (2015); Bureau of Land Mgmt., DOI-BLM-NM-F010-2014-0154-EA, Environmental Assessment for October 2014 Competitive Oil and Gas Lease Sale 28 (2014); Bureau of Land Mgmt., DOI-BLM-NM-040-2013-54-EA, Environmental Assessment for February 2014 Competitive Oil and Gas Lease Sale 25 (2013); 


\section{B. United States Forest Service}

USFS frequently acts as the lead agency in NEPA reviews for oil, gas, and coal projects on NFS land. Like BLM, USFS did not initially evaluate downstream greenhouse gas emissions and is now beginning to quantify and disclose these emissions in EISs, but its approach has also been somewhat inconsistent. In a 2012 EIS for two federal coal lease modifications, the agency disclosed $\mathrm{CO}_{2}$ emissions from the combustion of the coal that was anticipated to be produced under the leases. ${ }^{129}$ However, that same year, USFS released an EIS for a rule that would open federal forests to coal mining which did not disclose combustion-related emissions. ${ }^{130}$ The Colorado District Court held that this omission was arbitrary and capricious, ${ }^{131}$ and USFS prepared a revised draft EIS that included a much more detailed analysis of greenhouse gas emissions from mining, transportation (both within the U.S. and to overseas markets) and combustion. ${ }^{132}$

USFS has also been inconsistent in its reviews of oil and gas development projects. USFS conducted a life cycle assessment for an oil and gas leasing decision in 2013, which quantified emissions from transport, refining, and end use. ${ }^{133}$ But in 2014, the agency released an EIS for another oil and gas leasing decision where it concluded that it was impossible to quantify downstream emissions from oil and gas development because the end uses of these resources were unknown. ${ }^{134}$ In another oil and gas EIS released that same year, USFS did

Bureau of Land Mgmt., DOI-BLM-NM-P010-2013-63-EA, Environmental AsSessment for April 2013 Competitive Oil and Gas Lease Sale 18 (2012).

129. U.S. Forest Serv., Final Environmental Impact Statement, Federal Coal Lease Modifications COC-1362 \& COC-67232 at 80 (2012).

130. U.S. Forest Serv., 2 Rulemaking for Colorado Roadless Areas, Final EnviRonmental Impact Statement (2012).

131. High Country Conservation Advocates v. U.S. Forest Serv., 52 F. Supp. 3d 1174, 1196 (D. Colo. 2014).

132. U.S. Forest Serv., Rulemaking for Colorado Roadless Areas, Supplemental Draft EnVironmental Impact Statement 33 (2015).

133. U.S. Forest Serv., Record of Decision and Final Environmental Impact Statement, Oil and Gas Leasing Analysis, Fishlake National Forest, Utah 169 tbl. 3.12-7 (2013) (showing GHG emissions from transportation, refining, transportation of refined resources, and end use are 299,627 $\mathrm{MT} \mathrm{CO}_{2} \mathrm{e}$; total direct and indirect emissions are 365,336 $\mathrm{MT} \mathrm{CO}_{2} \mathrm{e}$ ). See also id., at app. E/SIR-2 (showing more detailed calculations of direct and indirect emissions).

134. U.S. Forest Serv., Pawnee National Grassland Oil and Gas Leasing Analysis, Final Environmental Impact Statement 188 (2014) (“The numbers provided . . . do not include greenhouse gas emissions that would result from processing the extracted oil and gas into final products or from the end use of those products. This is because it is not possible to determine what the volume or quality of extracted oil and gas will be or which types of products will ultimately be derived from the oil and gas. It is also not possible to forecast where, how, or when products extracted from the project area will be used. Oil, for 
not disclose greenhouse gas emissions for very different reasons-the agency noted that the "end use of natural gas for heating and electricity would also contribute to GHG emissions" yet concluded that the potential development of oil and gas resources is "not expected to produce a measurable or significant impact" and that the "demand for this energy source would likely result in its development elsewhere." 135

\section{Federal Energy Regulatory Commission}

FERC is the lead agency on environmental reviews of pipelines, LNG export facilities, and associated infrastructure (e.g., compressor stations and liquefaction facilities). Unlike BLM and USFS, FERC has consistently maintained that it has no obligation to consider greenhouse emissions or any other environmental effects associated with upstream and downstream activities in the natural gas production and supply chain. FERC's primary arguments against evaluating these emissions as indirect (or even cumulative) impacts are that they are: (i) too speculative to be analyzed in a meaningful way, or (ii) not caused by the proposed action. ${ }^{136}$ FERC has also insisted on conducting separate environmental reviews for different segments of natural gas pipelines, and for multiple facilities with very similar characteristics (e.g., LNG export terminals).

This has led to a series of lawsuits alleging that FERC is in violation of NEPA. Since 2014, the Sierra Club and other environmental organizations have challenged six separate FERC orders in the D.C. Circuit and the Second Circuit, citing the agency's failure to evaluate upstream and downstream impacts and other deficiencies with the NEPA analysis. One of these cases was

example, can be used to produce many types of products, including diesel fuel, gasoline, aircraft fuel, kerosene, motor oils, plastics, solvents, lubricants, tires, asphalt, and a myriad of other possible end products. Natural gas could be used for electrical generation, home heating, home cooking, as a vehicle fuel, in fertilizer production (via the Haber-Bosch process), and for other uses.").

135. U.S. Forest Serv., White River National Forest Oil and Gas Leasing, Final EnVironmental Impact Statement 132 (2014).

136. See, e.g., Order Denying Rehearing and Dismissing Stay Request, Algonquin Gas Transmission, LLC, 154 FERC 9 61,048, *44-46 (Jan. 28, 2016); Order Denying Rehearing, Sabine Pass Liquefaction Expansion, LLC, Sabine Pass Liquefaction, LLC, Sabine Pass LNG L.P., Cheniere Creole Trail Pipeline, L.P., 151 FERC \ 61,253, 62,671-73 (June 23, 2015); Order Denying Rehearing, Corpus Christi Liquefaction, LLC, Cheniere Corpus Christi Pipeline, L.P., 151 FERC \ 61,098, 61,651-54 (May 6, 2015); Order Denying Rehearing and Stay, Dominion Cove Point LNG, 151 FERC 9 61,095, 61,635-36 (May 4, 2015); Order Denying Rehearing and Clarification, Freeport LNG Dev., L.P., FLNG Liquefaction, LLC, 149 FERC 9 61,119, 61,776 (Nov. 3, 2014); Order Denying Rehearing, Cameron LNG, LLC, Cameron Interstate Pipeline, LLC, 148 FERC 9 61,237, 62,448-49 (Sept. 26, 2014). 
voluntarily dismissed. ${ }^{137}$ Three others have been decided in favor of FERC, for reasons discussed in Part IV. ${ }^{138}$ The remaining cases are still awaiting decisions from the D.C. Circuit Court of Appeals ${ }^{139}$ and the Second Circuit Court of Appeals. ${ }^{140}$

Notably, despite its insistence that upstream and downstream effects need not be evaluated in NEPA reviews, FERC does briefly discuss the beneficial implications of these effects in some EISs, noting that some of the natural gas projects could offset the use of oil and this will reduce greenhouse gas emissions. But the agency does not provide a complete analysis of downstream emissions or market impacts to actually support this conclusion. ${ }^{141}$

\section{Bureau of Ocean and Energy Management}

The BOEM conducts NEPA reviews for offshore oil and gas drilling plans and leases. In the past, BOEM did not account for downstream greenhouse gas emissions associated with the transportation, processing and end use of the oil and gas produced as a result of its decisions. ${ }^{142}$ In response to com-

137. Sierra Club \& Gulf Restoration Network v. Fed. Energy Regulatory Comm'n, No. 14-1190, 2015 WL 1606900 (D.C. Cir. Mar. 16, 2015).

138. Earthreports, Inc., v. Fed. Energy Regulatory Comm'n, No. 15-1127 2015 U.S. app. LEXIS 23146 (D.C. Cir. July 15, 2016); Sierra Club v. Fed. Energy Regulatory Comm'n, No. 141249 (D.C. Cir. June 28, 2016); Sierra Club \& Galveston Baykeeper v. Fed. Energy Regulatory Comm'n, No. 14-1275 (D.C. Cir. June 28, 2016); Sierra Club v. Fed. Energy Regulatory Comm'n, No. 15-1133 (D.C. Cir. Jan. 12, 2016). See infra Part IV.B.3.

139. Sierra Club v. Fed. Energy Regulatory Comm'n, No. 15-1133 (D.C. Cir. May 11, 2015).

140. Catskill Mountainkeeper, Inc. v. Fed. Energy Regulatory Comm'n, No. 16-345 (2d Cir. Feb. 5, 2016).

141. See, e.g., Fed. Energy Regulatory Comm'n, Rockaway Delivery Lateral Project and Northeast Connector Project Final Environmental Impact StateMENT 4-215 to 4-217 (2014) (predicting that pipeline will lead to decrease in fuel oil use, displacing 11,357 $\mathrm{MT} \mathrm{CO}_{2}$ e daily); Fed. Energy Regulatory Comm'n, Constitution Pipeline Project and Wright Interconnect Project Final Environmental ImPACT STATEMENT 4-256 (2014) (anticipating some displacement of greenhouse gases from burning fuel oil).

142. See, e.g., Bureau of Ocean \& Energy Mgmt., Gulf of Mexico OCS Oil and Gas Lease Sales: 2016 and 2017, Central Planning Area lease Sales 241 and 247 and Eastern Planning Area Lease Sale 226, Final Supplemental Environmental Impact Statement (2015); Bureau of Ocean \& Energy Mgmt., Gulf of Mexico OCS Oil and Gas Lease Sales: 2015 and 2016, Western Planning Area Lease Sales 246 and 248, Final Supplemental Environmental Impact Statement (2015); Bureau of Ocean \& Energy Mgmt., Atlantic OCS Proposed Geological and Geophysical Activities, Mid-Atlantic and South Atlantic Planning Areas, Final Programmatic Environmental Statement, app. at L-172 (2014) (BOEM received a comment calling for consideration of downstream emissions as well as other climate-related effects, but did not specifically respond to this aspect of the comment, merely stating that it did "not believe that an analysis beyond that provided is necessary”); Bureau of Ocean \& Energy Mgmt., Outer Continental Shelf Oil 
ments calling for the consideration of downstream emissions, BOEM previously asserted that such emissions are "too remote and speculative to permit any meaningful analysis." ${ }^{143}$ However, BOEM has recently changed course: in the final EIS for its 2017-2022 Outer Continental Shelf Lease Plan, it evaluated life-cycle greenhouse gas emissions from oil and gas that could be produced under the program and from substitute energy sources and ultimately concluded that the proposal could result in modest emission reductions because the produced oil and gas would displace domestic coal and overseas fuel imports (which have higher transportation emissions). ${ }^{144}$

\section{E. Department of Energy}

DOE approval is required prior to the export of LNG from U.S. terminals to non-free trade agreement nations. But the agency does not typically prepare a separate Environmental Assessment ("EA") or EIS for these approvals, since FERC has already conducted a NEPA review for the export terminal. It is worth noting, however, that unlike FERC, DOE has begun to account for both upstream and downstream greenhouse gas emissions in the orders granting authorization to export LNG. ${ }^{145}$ To support this analysis, DOE conducted the two LNG studies discussed in Part I, supra, which estimate greenhouse emissions from all aspects of the LNG supply chain: production, processing, transportation and end use. ${ }^{146}$

\section{F. United States Army Corps of Engineers}

The Corps acts as the lead agency for NEPA reviews of projects that involve Corps authorizations (e.g., projects that involve the discharge of dredged and/or fill materials into waters of the United States, including wetlands). Such projects may include oil and gas pipelines, coal export terminals, and any other

and Gas Leasing Program: 2012-2017, Final Programmatic Environmental ImPACT STATEMENT (2012).

143. Bureau of Ocean \& Energy Mgmt., Outer Continental Shelf Oil and Gas Leasing Program: 2012-2017, Final Programmatic Environmental Impact Statement 8-37 (2012).

144. Bureau of Ocean \& Energy Mgmt., Outer Continental Shelf Oil and Gas Leasing Program: 2017-2022, Final Programmatic Environmental Impact STATEMENT $\S$ 4.2.1.2 (2016).

145. See, e.g., Freeport LNG Expansion, L.P., U.S. Dep't of Energy, Office of Fossil Fuels, Order No. 3357-B, 43, 45-54 (2014).

146. U.S. Dep't. of Energy, Addendum to Environmental Review Documents ConCerning Exports of Natural Gas From the United States (2014); U.S Dep't. of Energy, Life Cycle Greenhouse Gas Perspective on Exporting Liquefied NatURAL GAS (May 29, 2014). 
projects where one of the aforementioned agencies is not already conducting a NEPA review.

Based on two recent environmental reviews for fossil fuel-related projects, the Corps also appears to lack a consistent approach for analyzing upstream and downstream emissions. In 2012, the Corps published an EIS for an intrastate natural gas pipeline in Alaska (not subject to FERC jurisdiction). There, the agency estimated downstream emissions from combustion of the natural gas that would be transported, and also discussed the potential for natural gas to displace other, dirtier fuel sources such as coal and oil. ${ }^{147}$ But in the NEPA scoping documents for a coal terminal in Washington State, the Corps has asserted that it need not consider upstream or downstream impacts (including greenhouse gas emissions), despite multiple comments calling for consideration of such impacts, because they are not within the agency's jurisdiction. ${ }^{148}$ The Washington State Department of Ecology is also preparing an EIS for this project under its State Environmental Protection Act, and it does intend to account for downstream emissions. ${ }^{149}$ As noted in Part I, there are unique questions related to the scope of NEPA review for Corps approvals which are beyond the purview of this paper.

\section{G. Department of State}

The Department of State does not typically conduct NEPA reviews for fossil fuel extraction and infrastructure. But it did act as lead agency on the

147. U.S. Army Corps of Eng'rs, Final Environmental Impact Statement, Alaska Stand Alone Gas Pipeline 5.20-70-71 (2012).

148. U.S. Army Corps of Eng'rs, Scoping Summary Report, Proposed Gateway PaCific Terminal/Custer Spur 7-17 (2013) (“According to the Applicants, the extraction, long-range transport, and combustion of coal, including overseas activities, would lack a causal project relationship because the Corps does not have jurisdiction over these activities. Moreover, these activities, such as rail or mining operation, have previously been scrutinized and are already in business. Therefore, conducting an area-wide EIS in this situation would be unprecedented and require that all commodities shipped on the transportation network be studied for lifecycle impacts during an EIS for each new project.") Given that the Corps has more limited discretion when issuing Section 404 permits (it evaluates impacts on water resources, but not air quality), the agency has a more sound legal basis for making the jurisdictional argument than FERC, BLM, or any other agency with broad discretion to deny an application based on the public interest. But the agency's statement about the need to conduct a life-cycle analysis of all commodities is factually incorrect. There are readily available tools that can be used to calculate life-cycle greenhouse gas emissions from coal and which would make this analysis reasonably easy for the agency, many of which are listed in the Appendix. The life-cycle greenhouse gas emissions are therefore reasonably foreseeable, even if this is not true for all environmental impacts from all commodities shipped via the terminal.

149. Wash. State Dep't of Ecology, FaQ on Scope of Eis Studies for Gateway Pacific Terminal/Custer Spur (2014), https://perma.cc/NRY9-PNX4. 
Keystone XL Pipeline Review (because this pipeline crossed the U.S. border into Canada). ${ }^{150}$ For this project, the Department of State conducted a relatively comprehensive life-cycle greenhouse gas analysis for the proposed pipeline, alternatives, and baseline scenarios that could occur if the pipeline was not constructed (all of which were possible outcomes of the no-action alternative). This analysis included greenhouse gas emissions from production, processing, transportation and end use. ${ }^{151}$ It also conducted a market analysis to determine whether the pipeline would significantly affect the rate of oil extraction or use as compared with the baseline scenarios ("reference crudes"). ${ }^{152}$ The department ultimately concluded that the pipeline would not have a significant impact on greenhouse gas emissions, because it was unlikely to significantly affect the rate of oil extraction and consumption as compared with baseline scenarios. ${ }^{153}$ This conclusion was challenged by EPA in its comments on the EIS, where it noted that FERC had failed to account for decreased oil prices in the market analysis. ${ }^{154} \mathrm{EPA}$ also noted that the finding of no significant impact in this context was not supported by the agency's analysis, which revealed that the development of oil stands crude would, in fact, significantly increase greenhouse gas emissions as compared with the reference crudes. ${ }^{155}$ Rather than preparing a revised EIS, the State Department ultimately decided to terminate the project, citing environmental concerns including the impact of the pipeline on global greenhouse gas emissions and climate change. ${ }^{156}$

\section{H. Environmental Protection Agency}

EPA does not conduct environmental reviews for fossil fuel-related projects, but it does provide comments on EISs prepared by other agencies. EPA has a unique role in the commenting process-Section 309 of the Clean Air Act directs EPA to review and comment on the adequacy of the environmental impact analysis in a draft EIS, and to refer the matter to the CEQ in the event that the agency does not adequately respond to those comments in the final EIS. ${ }^{157}$

150. See Exec. Order 13,337, 3 C.F.R. 13,337 § 2 (2004).

151. U.S. Dep't of State, Final Supplemental Environmental Impact Statement FOR the Keystone XL Project § 4.14.3, app. U at 55 (2014).

152. Id. at $\S 1.4$.

153. Id. at ES-9.

154. Letter from Cynthia Giles, EPA, to Amos Hochstein \& Judith Garber, Dep't of State (Feb. 2, 2015) (on file with author).

155. Id.

156. Press Statement, John Kerry, Sec'y of State, Keystone XL Pipeline Permit Determination (Nov. 6, 2015).

157. 42 U.S.C.A. § 7609 (2012). 
EPA has consistently urged agencies to consider upstream and downstream emissions in the EISs for fossil fuel-related projects. In particular, EPA has repeatedly commented on FERC EISs for pipelines and LNG export facilities, pressing for: (i) the consideration of how such infrastructure may affect upstream natural gas development and (ii) a life-cycle greenhouse gas emissions analysis (and urging the agency to consider the DOE analysis of indirect greenhouse gas effects from LNG export facilities). ${ }^{158} \mathrm{EPA}$ also submitted comments on the scope of impacts that should be evaluated in the coal terminal EIS that the Corps is preparing, in which it urged the Corps to conduct a life-cycle assessment of greenhouse gas emissions from the coal that would be transported via the terminal. ${ }^{159}$

\section{Emerging Trends in NePA Case Law}

In the past five years, over a dozen lawsuits have been filed challenging the approval of fossil fuel extraction and infrastructure proposals because the lead agency failed to consider upstream and/or downstream greenhouse gas emissions during its NEPA review. This section surveys and synthesizes this emerging body of case law, addressing judicial review of agency assessments of indirect effects and related actions for both extraction and transportation actions. ${ }^{160}$

In regards to indirect effects: for extraction proposals, courts have consistently held that downstream emissions fall within the scope of indirect impacts that should be reviewed under NEPA and that emissions from combustion are "reasonably foreseeable" when production estimates are available. ${ }^{161}$ Emissions

158. See, e.g., Letter from Keith Hayden, EPA, to Kimberly D. Bose, Fed. Energy Regulatory Comm'n (Dec. 21, 2015) (commenting on the Magnolia LNG and Kinder Morgan Louisiana Pipeline projects); Letter from Keith Hayden, EPA, to Kimberly D. Bose, Fed. Energy Regulatory Comm'n (June 1, 2015) (commenting on the Lake Charles Liquefaction Project); Letter from Craig Weeks, EPA, to Kimberly D. Bose, Fed. Energy Regulatory Comm'n (Aug. 4, 2014) (commenting on the Corpus Christi Liquefaction and Pipeline projects).

159. Letter from Deniss J. McLerran, EPA, to Randel Perry, U.S. Army Corps of Eng'rs (Jan. 22, 2013) (commenting on the Gateway Pacific Terminal project).

160. It bears noting that NEPA decisions are highly fact-specific. The extent to which an agency is required to evaluate a particular environmental impact under NEPA depends on the information that is available to the agency and on the record. Thus, even if a court holds that an impact is too speculative to require consideration in the context of a particular project, a subsequent court may conclude that the same impact is reasonably foreseeable for a similar project if new information is available to facilitate the analysis of that impact. There are now many tools available to forecast greenhouse gas emissions from all stages of fossil fuel development, and thus courts may reach different conclusions about the scope of analysis required for the types of proposals discussed in the cases below. See Appendix.

161. Although courts have required consideration of combustion emissions in NEPA reviews for coal extraction and transportation, they have also deferred to agencies' decisions to only 
from transportation and processing may also fall within the scope of indirect impacts that are caused by the extraction of the resource, but the extent to which these emissions are "reasonably foreseeable" depends on the information available to the agency. The case law is less clear on the agency's obligation to evaluate upstream and downstream emissions in the context of transportation proposals such as pipelines and export terminals. Here, courts have, without much explanation, treated oil and gas pipelines differently than coal rail lines. ${ }^{162}$ Whereas courts have required consideration of upstream and downstream emissions in the context of coal rail line approvals, using the same principles as those applied in extraction cases, the courts have not yet required a similar analysis in the context of oil and gas pipelines. And, as discussed in Sec. IV.B.2.C, below, the courts' treatment of LNG export facilities has thus far proven unique.

In regards to related actions: There are very few decisions regarding the scope of an agency's obligation to evaluate connected, cumulative or similar fossil fuel-related proposals in the same EIS. ${ }^{163}$ However, there are principles from cases involving other types of projects that can also be used to understand the circumstances in which agencies should conduct a programmatic review of interconnected fossil fuel infrastructure.

evaluate the net increase in coal consumption (and corresponding emissions) caused by the additional production of coal. See infra Part IV.B.1; WildEarth Guardians v. Office of Surface Mining, Reclamation \& Enf t, No. CV 14-103-BLG-SPW, 2015 WL 6442724 (D. Mont. Oct. 23, 2015), report and recommendation adopted in part, rejected in part sub nom. Guardians v. Office of Surface Mining, Reclamation \& Enft, No. CV 14-103-BLG-SPW, 2016 WL 259285 (D. Mont. Jan. 21, 2016) (The Office of Surface Mining Reclamation and Enforcement ("OSMRE") failed to take hard look at environmental impacts when issuing a finding of no significant impact ("FONSI"), including downstream greenhouse gas emissions); Diné Citizens Against Ruining Our Env't v. Office of Surface Mining, Reclamation \& Enft, 82 F. Supp. 3d 1201 (D. Colo. 2015), order vacated in part, appeal dismissed in part, Diné Citizens Against Ruining our Env't v. Office of Surface Mining Reclamation \& Enf t, 643 Fed. App'x. 799 (10th Cir. 2016) (mem.); WildEarth Guardians v. Office of Surface Mining, Reclamation \& Enft, 104 F. Supp. 3d 1208, 1230 (D. Colo. 2015), order vacated, appeal dismissed, WildEarth Guardians v. Office of Surface Mining, Reclamation \& Enft, 652 Fed. App'x. 717 (10th Cir. 2016) (mem.); High Country Conservation Advocates v. U.S. Forest Serv., 52 F. Supp. 3d 1174 (D. Colo. 2014).

162. This issue is currently being litigated. For a discussion of four cases pending before the D.C. Circuit regarding the scope of upstream and downstream emissions that FERC must evaluate in its approval of natural gas pipelines and export facilities, see infra Part IV.B.3.

163. Delaware Riverkeeper Network v. Fed. Energy Regulatory Comm'n required FERC to conduct a joint review of different pipeline segments, 753 F.3d 1304, 1308-09 (D.C. Cir. 2014), and Kleppe v. Sierra Club held that a programmatic review of federal coal leasing was not required (but this was before agencies were contemplating greenhouse gas emissions and climate change in EISs), 427 U.S. 390, 409-10 (1976). See infra Part IV.C. 


\section{A. Standard of Review}

Agencies' NEPA documents are reviewed under the arbitrary and capricious standard set forth in Section 706 of the Administrative Procedure Act. In the NEPA context, a reviewing court must ensure that the agency has taken a "hard look" at the environmental consequences of the proposed action and reasonable alternatives. ${ }^{164}$ When conducting this inquiry, courts typically focus on whether the agency failed to consider an important aspect of the problem, or offered an explanation for its decision that runs counter to the evidence before the agency. ${ }^{165}$ Courts frequently set aside EISs where an agency has completely ignored an environmental impact - if the agency has conducted at least some analysis, the court is more likely to defer to its findings about the nature and significance of the impact. ${ }^{166}$ That said, a court will not defer to agency conclusions that are not supported by the evidence on the record. ${ }^{167}$

Courts also consider whether the environmental disclosures requested by plaintiffs would help serve the twin purposes of NEPA: informed decisionmaking and informed public participation. ${ }^{168}$ To answer this question, courts will apply the "rule of reason," which requires agencies to evaluate and disclose

164. See, e.g., Robertson v. Methow Valley Citizens Council, 490 U.S. 332, 350 (1989); Marsh v. Oregon Nat. Res. Council, 490 U.S. 360, 374 (1989); Kleppe, 427 U.S. at 410 n.21 (1976).

165. See, e.g., Latin Ams. for Soc. \& Econ. Dev. v. Adm'r of Fed. Highway Admin., 756 F.3d 447, 464 n.10 (6th Cir. 2014) cert. denied sub nom. Detroit Int'1 Bridge Co. v. Nadeau, 135 S. Ct. 1411 (2015); New Mexico ex rel. Richardson v. Bureau of Land Mgmt., 565 F.3d 683, 704 (10th Cir. 2009); Ctr. for Biological Diversity v. Nat'l Highway Traffic Safety Admin., 538 F.3d 1172, 1193 (9th Cir. 2008); Davis Mountains Trans-Pecos Heritage Ass'n v. Fed. Aviation Admin., 116 F. App'x 3, 8 (5th Cir. 2004); Sierra Club v. U.S. Army Corps of Eng'rs, 295 F.3d 1209, 1216 (11th Cir. 2002); Cent. S. Dakota Coop. Grazing Dist. v. Sec'y of U.S. Dep't of Agric., 266 F.3d 889, 894 (8th Cir. 2001); Hughes River Watershed Conservancy v. Johnson, 165 F.3d 283, 288 (4th Cir. 1999); Dubois v. U.S. Dep't of Agric., 102 F.3d 1273, 1285 (1st Cir. 1996); Sierra Club v. Marita, 46 F.3d 606, 619 (7th Cir. 1995); Sierra Club v. U.S. Army Corps of Eng'rs, 772 F.2d 1043, 1051 (2d Cir. 1985).

166. See, e.g., Baltimore Gas \& Elec. Co. v. Nat. Res. Def. Council, Inc., 462 U.S. 87, 101 (1983) (upholding the Nuclear Regulatory Commission's environmental analysis of nuclear waste storage options).

167. Barnes v. U.S. Dep't of Transp., 655 F.3d 1124, 1136-38 (9th Cir. 2011) (rejecting the Department of Transportation's unsupported statement that air traffic would increase at the same rate irrespective of airport expansion); Coal. for Canyon Pres. v. Bowers, 632 F.2d 774, 782, 782 n.3 (9th Cir. 1980) (rejecting unsupported statement in highway project EIS that "pollution would 'occur anyhow' because traffic was bound to increase," finding that this "fail[ed] to give decision makers who are removed from the initial decision sufficient data from which to draw their own conclusions about air, noise, and water pollution"); Fla. Wildlife Fed'n v. U.S. Army Corps of Eng'rs, 401 F. Supp. 2d 1298, 1324 (S.D. Fla. 2005) (finding Corps' argument that the "inevitability" of development somehow broke any causal connection to be unsupported by the record, and also legally untenable).

168. See U.S. Dep't of Transp. v. Pub. Citizen, 541 U.S. 752, 768 (2004); Robertson, 490 U.S. 349; Baltimore Gas $\mathcal{E}$ Elec. Co., 462 U.S. at 97. 
only that information which is useful to the decision-making process (e.g., because it will enable the decision-maker to fully consider environmental factors and make a reasoned choice among alternatives). ${ }^{169}$ If an EIS is missing information that is highly relevant to the question of whether the agency should implement the action, and the agency has the means to obtain that information, the courts generally require that it be included in the EIS.

Finally, when reviewing EISs and other NEPA documents, courts typically defer to CEQ's official interpretation of the statute. The Supreme Court has noted that CEQ's NEPA regulations are entitled to "substantial deference." ${ }^{170} \mathrm{CEQ}$ 's guidance documents are entitled to less deference than the regulations, but are nonetheless an important guidepost for courts. ${ }^{171}$ Even before CEQ issued formal NEPA regulations, the Supreme Court held that CEQ's determinations about NEPA (and its application to a particular project) are "entitled to great weight." 172

\section{B. Indirect Effects}

The NEPA regulations specify that indirect effects are "caused by the action and are later in time or farther removed in distance, but are still reasonably foreseeable." ${ }^{173}$ Courts conduct a two-pronged inquiry to determine whether a particular environmental impact qualifies: first, is there a sufficient causal connection between the proposed action and the environmental impact, and second, is the environmental impact reasonably foreseeable? To establish a sufficient causal connection between a proposed federal action and an environmental impact, courts ask whether the proposed action is a cause-in-fact of the impact, i.e., the impact would not occur but for the proposed action, and whether there is a "reasonably close causal relationship akin to proximate cause

169. Pub. Citizen, 541 U.S. at 754 ("[I]nherent in NEPA and its implementing regulations is a 'rule of reason,' which ensures that agencies determine whether and to what extent to prepare an EIS based on the usefulness of any new potential information to the decisionmaking process.").

170. Robertson, 490 U.S. at 355; Andrus v. Sierra Club, 442 U.S. 347, 358 (1979).

171. Recently, the Supreme Court signaled its dissatisfaction with the idea that agencies should be given greater deference when interpreting their own regulations (commonly referred to as Auer or Seminole Rock deference), but it has not wholly abandoned or rejected this form of deference. See, e.g., Perez v. Mortgage Bankers Ass'n, 135 S. Ct. 1199, 1208 n.4 (2015) (noting that even under Auer deference, "it is the court that ultimately decides whether a given regulation means what the agency says").

172. Warm Springs Dam Task Force v. Gribble, 417 U.S. 1301, 1310 (1974) (enjoining construction of a dam pending appeal of EIS, based in part on filings from CEQ concerning the inadequacy of the EIS).

173. 40 C.F.R. $§ 1508.8$ (b) (2016). 
in tort law." 174 An impact is "reasonably foreseeable" if it is "sufficiently likely to occur that a person of ordinary prudence would take it into account in reaching a decision." 175 The First Circuit has outlined a set of factors for determining whether an impact is definite enough to take into account or too speculative to warrant consideration, including the likelihood of the impact, the utility of the information to the looming decision, and whether the absence of such information now would foreclose its consideration later. ${ }^{176}$

Because the basic thrust of an agency's responsibilities under NEPA is to predict future environmental impacts, agencies must use "[r] easonable forecasting and speculation" to evaluate impacts even when there is uncertainty about the nature and timing of those impacts. ${ }^{177}$ Moreover, as noted in Part II.B, the NEPA regulations impose an affirmative obligation on agencies to procure information regarding reasonably foreseeable impacts when possible. ${ }^{178}$ Where the EIS contains information about induced growth or other indirect effects in the description or justification of the proposed action, the agency must use this information to evaluate indirect effects. ${ }^{179}$ The agency must also respond to such information when it is provided through public comments. ${ }^{180}$

To further clarify these obligations, some courts have used the analogy of "links in a chain" to describe the scope of indirect effects (and effects from

174. Pub. Citizen, 541 U.S. at 754 (citing Metro. Edison Co. v. People Against Nuclear Energy, 460 U.S. 766, 774 (1983)) (internal citations omitted).

175. City of Shoreacres v. Waterworth, 420 F.3d 440, 453 (5th Cir. 2005) (quoting Sierra Club v. Marsh, 976 F.2d 763, 767 (1st Cir. 1992). See also Mid States Coal. for Progress v. Surface Transp. Bd., 345 F.3d 520, 549 (8th Cir. 2003).

176. Marsh, 976 F.2d, 768 (citing Sierra Club v. Marsh 769 F.2d 868, 878 (1st Cir. 1985)); See also Massachusetts v. Watt, 716 F.2d 946, 952-53 (1st Cir. 1983).

177. Scientists' Inst. for Pub. Info., Inc. v. U.S. Atomic Energy Comm'n, 481 F.2d 1079, 1092 (D.C. Cir. 1973) (noting that the courts must therefore "reject any attempt by agencies to shirk their responsibilities under NEPA by labeling any and all discussion of future environmental effects as 'crystal ball inquiry'). See also City of Davis v. Coleman, 521 F.2d 661, 675 (9th Cir. 1975) ("The nature and extent of development which the project will induce is still uncertain. Davis' fears may be exaggerated. But currently available information and plain common sense indicate that it was hardly 'reasonable' for CDHW or FHWA to conclude, without further study, that the environmental impact of the proposed interchange will be insignificant.").

178. 40 C.F.R. $\S 1502.22$ (2015).

179. See, e.g., Tomac v. Norton, 240 F. Supp. 2d 45, 51-52 (D.D.C. 2003) (holding that because Bureau of Indian Affairs ("BIA") provided its own projections for socioeconomic growth caused by casino project, but did not discuss the associated impacts on air, water, etc., BIA could not say these impacts were "speculative" when it had provided the growth projections); Friends of the Earth, Inc. v. U.S. Army Corps of Eng'rs, 109 F.Supp.2d 30, 34 (D.D.C. 2000) ("Since the economic development of these areas is the announced goal and anticipated consequence of the casino projects, the Corps cannot claim that the prospect of indirect secondary development is 'highly speculative.").

180. Mid States Coal. for Progress, 345 F.3d at 537. 
related actions) that should be reviewed in NEPA documents. ${ }^{181}$ This analogy is helpful for thinking about the scope of NEPA analysis for greenhouse gas emissions from fossil fuel extraction and transportation projects. The various stages of fossil fuel production, transportation, processing and consumption can also be thought of as "links in a chain" which should be analyzed together. Thus far, most courts have agreed with this approach. ${ }^{182}$

The following sections address the common themes and issues that have recurred to date, and that will define the future direction of courts' review of upstream and downstream emissions analysis under NEPA's indirect effects requirement.

\section{Fossil Fuel Extraction}

Since 2014, there have been five district court decisions regarding the scope of downstream emissions that must be evaluated in NEPA reviews for coal lease modifications and other approvals involving the extraction of coal from federal lands. ${ }^{183}$ In four of these cases, district courts in Colorado and Montana determined that the responsible agencies failed to take the requisite "hard look" at downstream emissions from the combustion of the coal. ${ }^{184}$ In the

181. Sylvester v. U.S. Army Corps of Eng'rs, 884 F.2d 394, 400 (9th Cir. 1989) ("Environmental impacts are in some respects like ripples following the casting of a stone in a pool. The simile is beguiling but useless as a standard. So employed it suggests that the entire pool must be considered each time a substance heavier than a hair lands upon its surface. This is not a practical guide. A better image is that of scattered bits of a broken chain, some segments of which contain numerous links, while others have only one or two. Each segment stands alone, but each link within each segment does not.") See also Border Power Plant Working Grp. v. U.S. Dep't of Energy, 260 F. Supp. 2d 997, 1013 (S.D. Cal. 2003); Ocean Mammal Inst. v. Cohen, No. 98-CV-160, 1998 WL 2017631, at *8 (D. Haw. Mar. 9, 1998) affd sub nom. Ocean Mammal Inst. v. Cohen, 164 F.3d 631 (9th Cir. 1998); Fla. Audubon Soc'y v. Bentsen, 94 F.3d 658, 668-70 (D.C. Cir. 1996).

182. See, e.g., Border Power Plant Working Grp., 260 F. Supp. 2d at 1013-17 (holding environmental impacts of power plant in Mexico were indirect impacts of decision to construct electric transmission line because neither facility would exist without the other).

183. As discussed below, there is also a 2009 decision from the Ninth Circuit requiring analysis of downstream emissions from transporting and processing gold in the EIS for a proposed gold mine. There was considerable overlap between the issues in that case and those involving the scope of downstream emissions that must be analyzed for coal extraction. See S. Fork Band Council of W. Shoshone of Nevada v. U.S. Dep't of Interior, 588 F.3d 718 (9th Cir. 2009).

184. WildEarth Guardians v. Office of Surface Mining, Reclamation \& Enft, No. CV 14-103BLG-SPW, 2015 WL 6442724 (D. Mont. Oct. 23, 2015) report and recommendation adopted in part, rejected in part sub nom. WildEarth Guardians v. Office of Surface Mining Reclamation \& Enft, No. CV 14-103-BLG-SPW, 2016 WL 259285 (D. Mont. Jan. 21, 2016) (The OSMRE failed to take hard look at environmental impacts when issuing FONSI, including downstream greenhouse gas emissions); Diné Citizens Against Ruining Our Env't v. Office of Surface Mining Reclamation \& Enft, 82 F. Supp. 3d 1201 (D. Colo. 2015), order vacated in part, appeal dismissed in part, Diné Citizens Against Ruining Our 
fifth case, a district court in Wyoming held that the agency's analysis of downstream emissions was adequate, in part because the agency had already disclosed emissions from the combustion of the leased coal. ${ }^{185}$ There has not yet been any decision regarding an agency's obligation to evaluate downstream emissions in the context of oil or gas extraction, but environmental groups have filed a lawsuit challenging 397 oil and gas leases because BLM failed to account for such emissions in the NEPA reviews for these leases. ${ }^{186}$

In all of these cases, the government defendants have argued that they did not need to account for downstream emissions (specifically, emissions from combustion) because the production of the coal would not lead to an increase in coal consumption. In some cases, the government defendants also argued that those emissions were too speculative to be forecasted. The courts have disagreed, finding that there is a sufficient causal connection between the extraction of coal and the downstream greenhouse gas emissions from the end use of the extracted coal. In doing so, the courts have rejected three types of arguments against causation, which we will refer to as the "status quo" argument, the "perfect substitute" argument, and the "it's not our call" argument. In addition, courts have held that emissions from combustion are foreseeable impacts and can be quantified when data is available about the amount of coal that will be produced.

Env't v. U.S. Office of Surface Mining Reclamation \& Enft, 643 Fed. App'x. 799 (10th Cir. 2016) (mem.) (The OSMRE must consider downstream emissions from coal combustion); WildEarth Guardians v. Office of Surface Mining, Reclamation \& Enft, 104 F. Supp. 3d 1208, 1230 (D. Colo. 2015), order vacated, appeal dismissed, WildEarth Guardians v. Office of Surface Mining, Reclamation \& Enft, 652 Fed. App'x. 717 (10th Cir. 2016) (mem.) (The OSMRE must consider downstream emissions from coal combustion); High Country Conservation Advocates v. U.S. Forest Serv., 52 F. Supp. 3d 1174 (D. Colo. 2014) (USFS must consider downstream emissions from coal combustion). See also Office of Surface Mining, Reclamation \& Enft, Nos. 15-1186 and 15-1236 (10th Cir. June 17, 2016) (dismissing as moot the mining companies' appeal from the District of Montana's decision in Guardians v. OSMRE after the OSMRE completed new NEPA analysis that complied with the court order).

185. WildEarth Guardians v. U.S. Forest Serv., 120 F. Supp. 3d 1237 (D. Wyo. 2015).

186. WildEarth Guardians v. Jewell, No. 1:16-cv-01724 (D.C. Cir. filed Aug. 25, 2016). The obligation to assess downstream emissions from oil and gas production was also raised in a recent administrative objection to the USFS's EIS for the Pawnee National Forest. There, WildEarth Guardians praised USFS for estimating emissions from oil and gas consumption, but argued that USFS had improperly concluded that the "post-leasing development of oil and gas" would have a "negligible" and "inconsequential" effect on greenhouse gas emissions. In its response to the objection, USFS found that there was no violation of law and thus no need to revise the analysis. USFS did not specifically elaborate on its obligation to evaluate downstream emissions from oil and gas development. See Notice of Objection, Statement of Reasons and Request for Relief, WildEarth Guardians v. Casamassa (U.S. Forest Serv. filed Jan. 20, 2015); U.S. Forest Serv. Objection Response, WildEarth Guardians v. Casamassa (U.S. Forest Serv., Feb. 6, 2015). 
These holdings are generally consistent with our interpretation of what NEPA requires in this context: the combustion of coal is a reasonably foreseeable indirect effect of coal extraction, and emissions from combustion should therefore be considered in NEPA reviews for coal leases.

\section{a. The "Status Quo"}

The "status quo" argument has arisen in the context of proposals to reauthorize or expand mines that are already in operation, where agencies have asserted that the continued operation of the mine will not increase the rate at which coal is extracted and thus they will not increase combustion emissions as compared with the status quo. ${ }^{187}$ The Ninth Circuit's decision in South Fork Band of Western Shoshone of Nevada v. U.S. Department of Interior, which did not involve fossil fuels or greenhouse gas emissions, sets the stage for later courts' treatment of this line of argument. In that case, a group of Native American tribes challenged BLM's approval and corresponding NEPA review of a gold mine, and alleged that BLM had failed to analyze the air quality impacts of transporting and processing the gold ore that would be generated as a result of the mining approval. Causation was not an issue, as it was well known that the ore would be transported via an established route to an existing gold processing facility. Instead, BLM argued that the emissions need not be analyzed because it did not forecast any change in the rate of shipping and processing - and thus the proposed action would not cause an increase in emissions over the status quo. ${ }^{188}$ The court flatly rejected this argument, noting that "the mine expansion will create ten additional years of such transportation that is, ten years of environmental impacts that would not be present in the noaction scenario." 189

Subsequently, in Diné Citizens Against Ruining Our Environment v. U.S. Office of Surface Mining Reclamation and Enforcement, a district court judge in Colorado rejected the same argument in a case directly implicating greenhouse gases. Here, the Office of Surface Mining Reclamation and Enforcement ("OSMRE") had published an EA for the proposed expansion of a coal mine, in which it concluded that there would be no significant air quality effects. The EA analyzed the effects of mining and transporting coal to a specific power plant, but did not consider the effects of coal combustion. ${ }^{190}$ As with the South Fork Band of Western Shoshone case, causation itself was not an issue: The mine supplied coal directly to a power plant, and the proposed expansion of the mine was necessary for the mine to continue meeting its contractual obligations to

187. S. Fork Band Council of W. Shoshone, 588 F.3d at 725; Diné Citizens Against Ruining Our Env't, 82 F. Supp. 3d at 1217, appeal dismissed (Aug. 18, 2015).

188. S. Fork Band Council of W. Shoshone, 588 F.3d at 725.

189. Id. at $725-26$.

190. Diné Citizens Against Ruining Our Env't, 82 F. Supp. 3d at 1213. 
that plant. Moreover, it was not economically feasible for the plant to secure coal from any other source. Thus, all parties agreed, "but for [OSMRE's] approval of the permit revision application, coal would not be mined ... and the environmental impacts associated with the combustion of the mined coal would not occur." ${ }^{191}$ Accordingly, plaintiffs argued that the effects of coal combustion must be considered as "indirect effects" of the action. ${ }^{192}$ The OSMRE argued that the proposed mine expansion would not change the status quo with respect to the rate of coal combustion at the power plant. The court found for plaintiffs, noting that even if the proposed expansion does not increase the rate of coal combustion at the power plant it would allow the mine to continue supplying coal, resulting in the combustion of an additional 12.7 million tons of coal over the term of the supply contract. ${ }^{193}$ The court held that the agency must therefore account for the effects of continuing coal combustion as compared with what would happen if the mine expansion were not authorized.

In short, courts have rejected the "status quo" argument, holding that the continued operation of mines generates additional emissions over a period of time even if it does not change the rate at which those emissions are generated, and this effect must be evaluated under NEPA. ${ }^{194}$

\section{b. The "Perfect Substitute"}

The "perfect substitute" argument posits that the extraction of fossil fuels will not actually cause an increase in consumption, because the same quantity of the fuel would be produced elsewhere and eventually transported and consumed, even if the agency did not approve the proposal at issue. ${ }^{195}$ Here, recent cases begin to give shape to NEPA's requirements: at least one court expressly rejected it, finding that this proposition was illogical and defied current knowledge about how fossil fuel markets operate, but another court implicitly accepted the argument without any explanation of its decision.

High Country Conservation Advocates v. United States Forest Service was the first case that specifically examined an agency's obligation to evaluate downstream greenhouse gas emissions from coal production in NEPA reviews. ${ }^{196}$ The case involved two related EISs—one for a proposed exemption to the Colorado Roadless Rule to allow road construction for coal-related activities on approximately 20,000 acres of previously undeveloped national forest ("Colo-

191. Id. at $1212-13$ (citing Respondents' Brief at 36).

192. Id. at 1212 .

193. Id. at 1214.

194. Id.; S. Fork Band Council of W. Shoshone, 588 F.3d at 725-26.

195. See, e.g., Bureau of Land Mgmt., Final Environmental Impact Statement for the Wright Area Coal Lease Applications 4-141 (2010).

196. High Country Conservation Advocates v. U.S. Forest Serv., 52 F. Supp. 3d 1174 (D. Colo. 2014). 
rado Roadless Rule EIS"), and another for the proposed modification of two existing coal leases to add some of those newly opened lands to the leases ("Lease Modification EIS"). USFS prepared both EISs in conjunction with BLM. In the Lease Modification EIS, the agencies acknowledged that greenhouse gas emissions from the combustion of coal should be evaluated as indirect effects and estimated those emissions along with emissions from the mining operations. ${ }^{197}$ However, in the Colorado Roadless Rule EIS, the agencies did not estimate emissions from future mining operations or coal combustion. The agencies argued, in part, that combustion emissions need not be disclosed because the overall amount of coal consumed by the marketplace would remain unchanged because there are perfect substitutes for the coal that would be produced. ${ }^{198}$

The U.S. District Court for the District of Colorado disagreed, finding that the argument was illogical because the production of coal under the exemption will "increase the supply of cheap, low-sulfur coal" and "this additional supply will impact the demand for coal relative to other fuel sources, and coal that otherwise would have been left in the ground will be burned."199 Thus, the court held that "this reasonably foreseeable effect must be analyzed, even if the precise extent of the effect is less certain." 200 The court also held that the agencies had failed to engage with an expert report submitted by plaintiffs during the comment period, which refuted the agencies' conclusions about perfect substitution, violating the NEPA regulations that require agencies to respond to comments in the final EIS. ${ }^{201}$

The court's thoughtful critique of this argument in High Country Conservation Advocates can be contrasted to a more recent decision, WildEarth Guardians v. U.S. Forest Service, where a district court judge in Wyoming upheld an EIS that contained the "perfect substitute" argument without addressing the plaintiff's assertion that this argument was unsupported by the facts. ${ }^{202}$ The case involved an EIS for six coal lease approvals in which BLM had quantified emissions from combustion of the leased coal but ultimately concluded that these emissions would probably not differ under the proposed action and the no action alternative because there were other sources of coal that could be substituted for this one. BLM also noted that the transportation of coal via rail would

197. Id. at 1190 (the court nonetheless held that the agencies' analysis was inadequate, because they had quantified the economic benefits of coal production but had not used the federal Social Cost of Carbon ("SCC") tool to quantify the economic costs of coal production).

198. Id. at 1196.

199. Id. at 1198.

200. Id.

201. Id. (citing 40 C.F.R. § 1502.9(b)) (2016).

202. See WildEarth Guardians v. U.S. Forest Serv., 120 F. Supp. 3d 1237 (D. Wyo. 2015). 
generate greenhouse gas emissions, but did not quantify those emissions due to a lack of information. ${ }^{203}$

WildEarth Guardians asserted that BLM provided "no information or analysis" to support its conclusion that emissions would not change under the no-action alternative, and that BLM had ignored economic analysis to the contrary as well as recent case law rejecting the "perfect substitute" argument. ${ }^{204}$ But the court apparently misunderstood this aspect of the plaintiff's brief: in its summary of the case, the court states that "[plaintiffs] assert that climate impacts will not change under the No Action Alternative." ${ }^{205}$ That is precisely the opposite of what the plaintiffs were asserting. Apart from that statement, the court did not address plaintiffs' concerns about BLM's use of the perfect substitute argument. The court held that BLM's analysis of downstream impacts was adequate, because the agency had accounted for the effect of the proposed extraction on the combustion of coal and had identified areas of uncertainty. ${ }^{206}$ The case has now been appealed to the Tenth Circuit Court of Appeals. ${ }^{207}$

None of the other decisions involving fossil fuel extraction have directly confronted the perfect substitution argument. There is, however, a clear parallel between this and the status quo argument that was rejected in South Fork Band of Western Shoshone and Diné Citizens. When arguing that there is a "perfect substitute" for the extracted resource, agencies are essentially arguing that the rate of extraction and consumption will not increase within a given period, without considering whether the duration may be prolonged. ${ }^{208}$ Moreover, as discussed below, courts have also rejected the perfect substitute argument in the context of NEPA reviews for coal rail lines. ${ }^{209}$

203. Id. at 1272 .

204. Petitioner's Opening Brief at 50-51, WildEarth Guardians v. Bureau of Land Mgmt., No. 13-CV-00042 (D. Wyo. Aug. 17, 2015) (citing Mid States Coal. for Progress v. Surface Transp. Bd., 345 F.3d 520 (8th Cir. 2003)).

205. WildEarth Guardians, 120 F. Supp. 3d at 1246.

206. $I d$. at 1272 . The court did not specifically examine whether the agency had reasonably concluded that transportation emissions were too speculative to quantify because the plaintiffs had not specifically raised this issue in their complaint.

207. WildEarth Guardians v. U.S. Bureau of Land Mgmt., No. 15-8109 (10th Cir. filed Oct. 9, 2015).

208. This appears to be the case for the FEIS at issue in Wild Earth Guardians, 120 F. Supp. 3d 1237. See Bureau of Land Mgmt., Final Environmental Impact Statement for the Wright Area Coal Lease Applications 4-141 (2010) (noting that issuance of the coal leases probably would not affect U.S. $\mathrm{CO}_{2}$ emissions because there are other sources that could supply the demand for coal, without considering whether the approval of leases would affect the duration of coal production and consumption in the long term).

209. See infra Part IV.B.2.a. 


\section{c. Disclaiming Discretion: "It's Not Our Call"}

The third argument proffered by agencies in defense of not assessing downstream emissions as indirect effects is that there is not a "reasonably close causal relationship akin to proximate cause" between the extraction of the coal and emissions from downstream activities such as the combustion of the coal, because the agency lacks jurisdiction over those activities. To support this argument, agencies typically cite Department of Transportation v. Public Citizen. ${ }^{10}$ In Public Citizen, the Supreme Court held that an agency need not consider environmental effects in its NEPA review when it has "no ability" to adopt a course of action that could prevent or otherwise influence those effects. ${ }^{211}$ The Court noted that the agency's lack of such discretion was a "critical feature" of the case. It explained that there was no reason to collect and analyze information about a particular set of impacts when the agency "simply lacks the power to act on" that information. ${ }^{212}$

Reviewing courts have determined that agencies' reliance on this case is misplaced because they do have the power to act on information about downstream emissions from leased fossil fuels. As noted in Part I, BLM and USFS have considerable discretion to account for environmental concerns, including downstream emissions, when deciding whether and to what extent federal lands should be made available for fossil fuel leasing. Moreover, downstream emissions - particularly those from the combustion of fossil fuels-are clearly relevant to the question of whether the agency should authorize their extraction. Thus, the holding in Public Citizen does not, on its face, apply to these types of decisions. Moreover, the interpretation of Public Citizen advanced by some government agencies would directly contradict the NEPA regulations calling for consideration of "growth-inducing effects" and decades of case law requiring

210. U.S. Dep't of Transp. v. Pub. Citizen, 541 U.S. 752, 770 (2004).

211. The narrow holding in Public Citizen was based on a very specific set of facts. The President had announced plans to lift a moratorium on the operation of Mexican motor carriers in the United States, pending the promulgation of application and safety-inspection regulations. Pursuant to the President's directive, the Federal Motor Carrier Safety Administration ("FMCSA") published the proposed rules and an accompanying EA. The EA did not account for the environmental impacts from the increased presence of Mexican trucks in the United States, concluding that this impact was a result of the moratorium being lifted, and not the promulgation of application and safety requirements. The Supreme Court affirmed FMCSA's decision because it found that FMCSA had absolutely "no ability" to exclude Mexican motor carriers from operating within the United States, and thus there was an insufficient causal relationship between FMCSA's proposed regulations and the environmental impacts of those carriers operating in the United States. See id. at 766-70 (citing FMCSA's statutory obligations under 49 U.S.C. § 13902(a)(1) (2012)).

212. Id. at 768 ("[T] he environmental impact of the cross-border operations would have no effect on FMCSA's decision-making-FMCSA simply lacks the power to act on whatever information might be contained in the EIS."). 
agencies to evaluate the effect of their proposals on patterns of private development and other activities outside of their jurisdiction. ${ }^{213}$

Accordingly, in Diné Citizens Against Ruining Our Environment, a district court rejected the OSMRE's argument that it lacked authority over operations at the power plant to be fed by the mine and thus had "no ability to prevent" the emissions. ${ }^{214}$ The court noted that the OSMRE's regulations allow it to deny the proposed mine expansion based on environmental considerations and Public Citizen was therefore inapposite. ${ }^{215}$ The court reached the same decision in WildEarth Guardians v. U.S. Office of Surface Mining Reclamation and Enforcement, a case similar to Diné Citizens and decided on similar grounds. ${ }^{216}$

\section{d. The Foreseeability of Downstream Emissions}

With regards to foreseeability, the courts have often held that agencies have sufficient data and tools to estimate greenhouse gas emissions from the combustion of coal. They have also recognized that tools are available to evaluate how the extraction of coal will influence coal markets. However, the courts have not directly addressed whether greenhouse gas emissions from coal transportation and processing are also "reasonably foreseeable" - at least to the extent that they would warrant quantitative disclosure. ${ }^{217}$

For example, in High Country Conservation Advocates v. U.S. Forest Service, the federal agencies assessing the environmental impacts of the Colorado

213. City of Davis v. Coleman, 521 F.2d 661, 675 (9th Cir. 1975). See also, e.g., Border Power Plant Working Grp. v. U.S. Dep't of Energy, 260 F. Supp. 2d 997, 1017 (S.D. Cal. 2003); Friends of the Earth, Inc. v. U.S. Army Corps of Eng'rs, 109 F. Supp. 2d 30, 33 (D.D.C. 2000).

214. Diné Citizens Against Ruining Our Env't v. Office of Surface Mining, Reclamation \& Enft, 82 F. Supp. 3d 1201, 1217 (D. Colo. 2015) (citing U.S. Dep't of Transp. v. Pub. Citizen, 541 U.S. 752, 770 (2004)).

215. See Diné Citizens Against Ruining Our Env't, 82 F. Supp. 3d at 1217 (citing 30 C.F.R. $\S 773.15(\mathrm{j})$ (2016) requiring the OSMRE to ensure that endangered species will not be harmed before approving the permit. Notably, these regulations also require assurance that the "operation has been designed to prevent material damage to the hydrologic balance outside the permit area." 30 C.F.R. § 773.15(e).

216. See WildEarth Guardians v. Office of Surface Mining, Reclamation \& Enf t, 104 F. Supp. 3d 1208, 1230 (D. Colo. 2015).

217. S. Fork Band Council of W. Shoshone of Nevada v. U.S. Dep't of Interior, 588 F.3d 718, 725 (9th Cir. 2009). Although there has been no formal decision regarding the scope of an agency's obligation to evaluate transportation or processing emissions in a NEPA review for coal extraction, there are several cases that have touched on this issue. See id. (requiring analysis of emissions from gold transportation and processing where information was available to calculate those emissions). See also Diné Citizens Against Ruining Our Env't, 82 F. Supp. 3d at 1213 (noting that transportation-related impacts had already been accounted for in the EIS); WildEarth Guardians v. U.S. Forest Serv., 120 F. Supp. 3d 1237 (D. Wyo. 2015) (upholding an agency's analysis of downstream emissions, and noting that transportation emissions had been briefly discussed but not quantified). 
Roadless Rule (USFS and BLM) did not estimate emissions from future mining operations or coal combustion to be permitted under the rule, reasoning that such emissions were too speculative. ${ }^{218}$ The district court rejected this argument, noting that the EIS contained detailed projections of coal removal and associated economic benefits which were based on three existing mines in the area. ${ }^{219}$ The agencies knew the methane emission rates from these mines and could use that information to project future mining emissions under the rule. ${ }^{220}$ The court also noted that the agencies' proffered explanation for omitting these emissions was 'belied by the agencies' decision to include detailed projections and analysis of tax revenue, employment statistics, and other environmental interests" in the EIS and that it was "arbitrary to offer detailed projections of a project's upside while omitting a feasible projection of the project's costs." 221

The court reached a similar conclusion about the agencies' ability to forecast combustion emissions. The agencies asserted that these emissions were too speculative to disclose because: (1) this would require analyzing the effects of coal that "may or may not be produced over a wide area from mines that may or may not be developed" as a result of the rule, (2) power plants have varying degrees of efficiency, and the emissions rate for the facilities that would consume this coal was unknown, and (3) currently unavailable technology like carbon capture and sequestration may be widely adopted by the time the coal is burned.222 The court quickly rejected the first argument, stating that:

The agency cannot — in the same FEIS—provide detailed estimates of the amount of coal to be mined and simultaneously claim that it would be too speculative to estimate emissions from 'coal that may or may not be produced' from 'mines that may or may not be developed.' The two positions are nearly impossible to reconcile. ${ }^{223}$

Turning to the second argument, the court noted that the agencies had estimated combustion emissions in the Lease Modifications EIS despite uncertainty about power plant efficiency and there was no reason that the agencies could not provide similar estimates in the Colorado Roadless Rule EIS. ${ }^{224}$ The

218. See High Country Conservation Advocates v. U.S. Forest Serv., 52 F. Supp. 3d 1174, 1196 (D. Colo. 2014).

219. See id.

220. Id.

221. Id. at 1195 (citing Scientists' Inst. for Pub. Info., Inc. v. U.S. Atomic Energy Comm'n, 481 F.2d 1079, 1097 (D.C. Cir. 1973)). See also id. (referencing Sierra Club v. Sigler, 695 F.2d 957, 979 (5th Cir. 1983) ('There can be no 'hard look' at costs and benefits unless all costs are disclosed.").

222. High Country Conservation Advocates, 52 F. Supp. 3d at 1196-97.

223. Id. at 1196-97 (internal citations omitted).

224. $I d$. at 1197 ("There is no reason to believe that variations in power plant efficiency posed no obstacle to making reasonable estimates of emissions associated with the Lease Modifications but that those same variations in efficiency posed an insurmountable hurdle to making 
court quickly dismissed the third argument as well, holding that the agencies "cannot rely on unsupported assumptions that future mitigation technologies will be adopted" to avoid disclosing environmental impacts. ${ }^{225}$

Similarly, in Diné Citizens Against Ruining Our Environment, the district court found that combustion emissions associated with a mine that fed a single power plant were reasonably foreseeable, because the agency knew where the coal would be consumed:

Unlike a scenario in which a coal mine markets its coal freely to multiple buyers, each of whom uses that coal in different applications under different constraints, there is virtually no uncertainty regarding when, where, and how the coal mined as a result of NTEC's proposed mine expansion will be combusted .... Because there is no uncertainty as to the location, the method, or the timing of this combustion, it is possible to predict with certainty the combustion-related environmental impacts. ${ }^{226}$

Importantly, the court's comment about the uncertainty of combustion emissions under an alternate scenario does not mean that such emissions need not be disclosed in NEPA reviews. Pursuant to the holding in High Country, such emissions must be disclosed even if there is uncertainty about where and when the coal will be combusted.

\section{Fossil Fuel Transportation}

Courts have looked at the scope of upstream and downstream emissions that should be evaluated in NEPA reviews of projects intended to transport fossil fuels from production to end use in different ways, depending on the nature of the transportation infrastructure. The first two cases on this question both involved rail lines built to transport coal: one case requiring consideration of downstream emissions from the combustion of the transported coal, and

estimates from coal combustion associated with the three identified mines in the North Fork exemption.").

225. Id. (comparing New York v. Nuclear Regulatory Comm'n, 681 F.3d 471, 478-79 (D.C. Cir. 2012) (finding a NEPA violation where the agency decided to ignore future impacts based only on "reasonable assurance[s]" that the impacts would be avoided later)). See also Neighbors of Cuddy Mountain v. U.S. Forest Serv., 137 F.3d 1372, 1381 (9th Cir. 1998) (holding that an EIS discussion of mitigation violated NEPA in part because it was "not clear whether any mitigation measures would in fact be adopted").

226. Diné Citizens Against Ruining Our Env't v. Office of Surface Mining, Reclamation \& Enft, 82 F. Supp. 3d 1201, 1213 (D. Colo. 2015), appeal dismissed LEXIS 45261 (D. Colo), vacated U.S. app. LEXIS 6107 (10th Cir. 2016). See also WildEarth Guardians v. Office of Surface Mining, Reclamation \& Enf t, 104 F. Supp. 3d 1208, 1230 (D. Colo. 2015) ("[T] he interdependence between the mines and the Craig Power Plant effectively guarantees the foreseeability of combustion-related effects."). 
another case requiring consideration of upstream emissions from the mining of the coal. In those cases, the courts confronted and dismissed several of the same arguments related to causation and foreseeability that were raised in the coal extraction cases. Perhaps the most important element of both cases was the courts' conclusions about causation. The courts found that the development of infrastructure intended to transport coal would affect the price of coal relative to other energy sources and this would affect patterns of coal production and consumption. Thus, the courts held that the reviewing agency must consider the emissions impacts from any increase in coal production or consumption caused by the construction of the rail lines. These holdings are consistent with our recommendations on the proper scope of NEPA review for these types of projects.

By contrast, courts have not yet issued any decisions requiring analysis of upstream or downstream emissions in NEPA reviews for oil and gas pipelines or LNG export terminals. Neither courts nor the agencies have yet offered any principled basis for why the scope of the indirect emissions analysis should differ for coal rail lines and pipelines, nor have they offered a compelling argument for finding that pipelines do not affect natural gas production and consumption in the same fashion that coal railways affect coal production and consumption. Given the similarities between these types of projects, the same standards should apply. As discussed in further detail below, the D.C. Circuit did explain why the scope of FERC reviews for the construction of LNG export terminals could be narrower than the scope of other NEPA reviews: DOE has the final say over whether to authorize exports, and as such, DOE is better positioned to act on information about upstream or downstream emissions from LNG exports. As we argue below, this makes sense, but requires DOE fulfill its obligation in order to hold water. This section looks in more detail at the cases and arguments that have been raised in each context.

\section{a. Rail Lines for Coal}

The Eighth Circuit's decision in Mid States Coalition for Progress v. Surface Transportation Board was the first involving an agency's obligation to address downstream emissions from the combustion of fossil fuels that would be transported as a result of the agency action. At issue was the STB's approval and EIS for the construction of and upgrade to rail lines to service coal mines in Wyoming's Powder River Basin. Petitioners argued that STB had failed to consider the air quality and greenhouse gas effects associated with an increase in the supply of low-sulfur coal to power plants that would occur as a result of this project. The court agreed. ${ }^{227}$

227. Mid States Coal. for Progress v. Surface Transp. Bd., 345 F.3d 520, 549 (8th Cir. 2003). 
The record before the agency included comments explaining that the "projected availability of 100 million tons of low-sulfur coal per year at reduced rates [would] increase the consumption of low-sulfur coal vis-à-vis other fuels" (e.g., natural gas), resulting in increased emissions of $\mathrm{CO}_{2}, \mathrm{~N}_{2} \mathrm{O}$, particulates, and mercury. ${ }^{228}$ STB acknowledged that many utilities "will likely shift to the lowsulfur variety of coal" supplied by the rail line, due to the need to comply with Clean Air Act restrictions on sulfur dioxide emissions. ${ }^{229}$ STB argued, however, that the shift would occur regardless of whether the new line is constructed, and that the new line would simply provide a shorter and straighter route for the transportation of this coal to power plants. ${ }^{230}$

The court disagreed with STB's perfect substitution argument. It noted that this proposition was "illogical at best" because the "increased availability of inexpensive coal will at the very least make coal a more attractive option to future entrants into the utilities market when compared with other potential fuel sources, such as nuclear power, solar power, or natural gas" and thus the project will "most assuredly affect the nation's long-term demand for coal.".231

With regards to foreseeability, STB further argued that it would "need to know where [the power plants] will be built, and how much coal these new unnamed power plants would use" in order to analyze emissions from induced coal consumption. The court disagreed, noting that even if the "extent of the effect" was speculative, the "nature of the effect" was "far from speculative" in this context. ${ }^{232}$ Where the "nature of the effect is reasonably foreseeable but its extent is not," the court held that the "agency may not simply ignore the effect," but rather must comply with the regulatory procedure for evaluating environmental impacts when there is incomplete or unavailable information. ${ }^{233}$ The court also noted that the agency had received comments describing computer programs that could be used to forecast the effects of this project on the consumption of coal..$^{234}$

On remand from Mid States Coalition, STB prepared a revised EIS with an updated analysis of downstream emissions based on the EIA's National Energy Modeling System ("NEMS"). STB concluded that the projected increase in $\mathrm{CO}_{2}$ and other air emissions would increase less than $1 \%$ based on this model. ${ }^{235}$ The adequacy of this analysis was challenged in a subsequent case, Mayo Foundation v. Surface Transportation Board, with one of the petitioners, Sierra Club, arguing that the utilization of this model was arbitrary and capri-

228. Id. at 548 .

229. Id. at 549 .

230. Id.

231. Id.

232. Id. (emphasis in original).

233. Id. at 549-50 (citing 40 C.F.R. $§ 1502.22$ (2016)) (emphasis in original).

234. Id. at 550 .

235. Mayo Found. v. Surface Transp. Bd., 472 F.3d 545, 555 (8th Cir. 2006). 
cious because STB continued to rely on the assumption that "not all of the ... transported coal would represent new combustion, that some would be simply a substitute for existing coal supplies." ${ }^{236}$ In other words, Sierra Club asserted that STB should have considered the impacts from the combustion of all of the transported coal, as opposed to the incremental addition in coal use as calculated by the NEMS model. The court dismissed this argument, noting that STB had "extensively discuss[ed] the potential impacts on air quality that may result from the implementation of the project." 237

Several years later, in Northern Plains Council v. Surface Transportation Board, the Ninth Circuit Court of Appeals held that STB is also required to evaluate emissions and other environmental impacts from coal mines in NEPA reviews of rail lines constructed to service those mines. Notably, petitioners in this case argued that methane emissions and other environmental impacts from the connected coal mines should be analyzed as cumulative effects (these are typically treated as indirect effects). The court's analysis therefore focused on whether these effects were reasonably foreseeable, since a cumulative impact need not be "caused" by the project. The court held that the emissions were clearly foreseeable for two reasons: (1) STB knew that the federal government had transferred land for these coal mines and the draft EIS included a map with the sites of future coal mines, (2) STB had relied on the coal mine development to justify the financial soundness of the proposal, and had even included tonnage forecasts in its final decision. ${ }^{238}$ Thus, STB's failure to disclose methane emissions from these mines was arbitrary and capricious.

Taken together, these cases have put the STB on notice that it should evaluate both upstream and downstream emissions in NEPA reviews for coal rail lines. However, as discussed below, the courts have not yet required a similar analysis for oil and gas pipelines, despite the similarities between these types of projects.

\section{b. Pipelines for Oil and Gas}

South Coast Air Quality Management District v. FERC, decided by the Ninth Circuit Court of Appeals in 2010, was the first case involving FERC's analysis of downstream emissions from the end use of natural gas in an EIS for a pipeline project. ${ }^{239}$ The case did not involve the agency's obligation to evaluate indirect greenhouse gas emissions, but rather emissions of conventional air pollutants. Petitioners argued that FERC had failed to adequately analyze the increase in nitrogen oxides $\left(\mathrm{NO}_{\mathrm{x}}\right)$ emissions that would result from the burning of

236. Id. at 556 .

237. Id.

238. N. Plains Res. Council, Inc. v. Surface Transp. Bd., 668 F.3d 1067, 1082 (9th Cir. 2011).

239. S. Coast Air Quality Mgmt. Dist. v. Fed. Energy Regulatory Comm'n, 621 F.3d 1085 (9th Cir. 2010). 
the natural gas transported via the pipeline. In response, FERC argued that such emissions would be generated from activities outside of its jurisdiction and were thus beyond the scope of its NEPA review. ${ }^{240}$

The court stated that it was unnecessary to determine whether FERC "was required under NEPA to analyze the environmental impacts of emissions resulting from the burning of gas supplied by the pipeline to consumers" because FERC explicitly stated that it considered those impacts in its EIS. ${ }^{241}$ Under these circumstances, the court held that the appropriate inquiry was whether FERC's analysis of downstream effects was adequate. ${ }^{242}$ Thus, the court did not reach FERC's jurisdictional argument. ${ }^{243}$

The court held that the EIS was adequate because "FERC explicitly considered the environmental impact of downstream emissions and imposed what it reasonably believed to be effective measures to mitigate the impact." ${ }^{244}$ Specifically, FERC had acknowledged concerns that the pipeline would "substantially increase emissions of the ozone precursor $\mathrm{NO}_{\mathrm{x}}$ in the South Coast Air Basin, directly affecting air quality and making attainment of the Federal air quality standards more difficult." ${ }^{45}$ Based on this conclusion, FERC determined that the pipeline certificate should be conditioned on the guarantee that the pipeline will "only deliver gas that meets the strictest applicable gas quality standards imposed by state regulatory agencies on downstream [local distribution companies] and pipelines." 246 FERC concluded that with this mitigation measure in place, the approval of the pipeline "should not result in a material increase in air pollutant emissions." 247

That same year, in Sierra Club v. Clinton, a district court in Minnesota held that the State Department was not required to evaluate upstream emissions in the EIS for a pipeline intended to transport Canadian tar sands oil to U.S. markets. ${ }^{248}$ The record and legal analysis were very different than those in South Coast Air Quality - that case dealt with how an agency should analyze downstream emissions (since FERC had conceded that the emissions would be

240. Id. at 1093.

241. Id.

242. $I d$.

243. Although the court did not reach FERC's jurisdictional argument, it is worth noting that the petitioners raised a compelling counterpoint to this argument in their brief: FERC's ability to impose restrictions on the type of natural gas delivered via the pipeline demonstrated that the commission had "abundant authority" to consider and mitigate air quality impacts in pipeline approvals, and thus distinguishes these approvals from the regulatory action at issue in Public Citizen. Brief for Petitioners at 44-47, S. Coast Air Quality Mgmt. v. Fed. Energy Regulatory Comm'n, 621 F.3d 1085 (9th Cir. 2010).

244. S. Coast Air Quality Mgmt., 621 F.3d at 1093-94.

245. Id. at 1093 (internal quotations omitted).

246. Id. (internal quotations omitted).

247. Id. (internal quotations omitted).

248. Sierra Club v. Clinton, 746 F. Supp. 2d 1025, 1045 (D. Minn. 2010). 
generated as a result of the project, causation was not an issue), whereas this case dealt with whether the pipeline would cause any upstream emissions that must be analyzed in the EIS.

The State Department argued that the development of the Canadian tar sands and the corresponding environmental impacts would occur regardless of whether it approved the proposed pipeline, and thus it need not analyze those impacts (echoing the "status quo" argument advanced by agencies in other cases). ${ }^{249}$

The court agreed, finding that the "administrative record demonstrates that the Canadian tar sands are being developed independently from the AC Pipeline project." ${ }^{250}$ In reaching this decision, the court cited the following findings from expert reports: (i) the production of crude oil from Canadian tar sands was already increasing at a rapid rate; (ii) the primary constraints on further tar sands development included lower crude oil prices, increased natural gas usage, and local infrastructure issues in Canada; (iii) there were other means of transporting the oil to the United States; and (iv) there were other markets where the oil could be consumed. ${ }^{251}$ The court further noted that the expert reports did not cite the "availability of pipeline capacity ... [as a factor] either driving or potentially impeding [tar sands] development." ${ }^{252}$ Thus, the court concluded, based on the record before it, that oil from the tar sands would be transported with or without the proposed pipeline.253

The third and final case to evaluate an agency's obligation to evaluate indirect emissions from pipeline development was Coalition for Responsible Growth and Resource Conservation v. FERC. This case, decided by the Second Circuit Court of Appeals, concerned the scope of upstream effects that FERC must consider in the approval and EA for a natural gas pipeline. The court issued a very short unpublished opinion finding that FERC's analysis was adequate because "FERC included a short discussion of Marcellus Shale development in the EA, and FERC reasonably concluded that the impacts of that development are not sufficiently causally-related to the project to warrant a more in-depth analysis." 254 Notably, the case is a summary order and therefore does not have precedential effect in the Second Circuit.

Another case challenging FERC's approval of a pipeline for failure to consider upstream emissions was filed in the Second Circuit in early 2016. ${ }^{255} \mathrm{In}$

249. Id. at 1044.

250. Id.

251. Id. at 1045.

252. Id.

253. Id.

254. Coal. for Responsible Growth \& Res. Conservation v. Fed. Energy Regulatory Comm'n, 485 F. App'x 472, 474 (2d Cir. 2012).

255. Catskill Mountainkeeper, Inc. v. Fed. Energy Regulatory Comm'n, No. 16-345 (2d Cir. filed Feb. 5, 2016). 
that case, the plaintiffs allege that there is "ample evidence that the current supply of natural gas in the areas around the Project is insufficient to fill the pipeline indefinitely and that the drilling of new wells is likely." ${ }^{256}$ For example, the plaintiffs submitted evidence showing that "the customers that have contracted to use the pipeline [also] have extensive commitments to other markets," and thus the gas supplied through their existing projects will be insufficient to fill the pipeline in the long term. ${ }^{257}$ The plaintiffs have also cited evidence that the types of unconventional wells that would supply the pipeline experience declines in production over time, requiring new wells be drilled to maintain supply. Finally, the plaintiffs note that FERC itself has acknowledged that "the supply of natural gas is an essential predicate to the Project but irrationally refuses to admit the connection between authorizing a new major pipeline and additional gas development in the area."258 Meanwhile, FERC maintains that the pipeline will not induce any additional natural gas production because other pipelines are available in the area, ${ }^{259}$ and in addition, that the specific location and timing of any induced natural gas production is "so nebulous" that FERC "cannot forecast [the] likely effects."260

It remains to be seen how the Second Circuit Court of Appeals will rule on the case. ${ }^{261}$ The Court of Appeals did deny the plaintiffs' motion to stay the pipeline construction pending resolution of the case, but the court provided no explanation with this order. ${ }^{262}$

256. Petitioners' Memorandum of Law in Support of Their Emergency Motion for a Stay Pending Review of Agency Orders at 10, Catskill Mountainkeeper, Inc. v. Fed. Energy Regulatory Comm'n., No. 16-345 (2d Cir. filed Feb. 5, 2016).

257. $I d$.

258. Id.

259. Respondent's Opposition to Emergency Motion for Stay Pending Review, Catskill Mountainkeeper, Inc. v. Fed. Energy Regulatory Comm'n, No. 16-345, 8-11 (2d Cir. filed Feb. 12, 2016).

260. Id. at 12 .

261. Coal. for Responsible Growth \& Res. Conservation v. Fed. Energy Regulatory Comm'n, 485 F. App'x 472 (2d Cir. 2012), will not be controlling, as it lacks precedential value. The same is true for the cases from other circuits.

262. Order Denying Stay, Catskill Mountainkeeper, Inc. v. Fed. Energy Regulatory Comm'n, No. 16-345 (2d Cir. Feb. 24, 2016). The briefs submitted thus far in this case indicate that one of the key issues will be the foreseeability of emissions. Importantly, as noted above, NEPA requires agencies to use "[r]easonable forecasting and speculation" to evaluate impacts even when there is uncertainty about the precise extent and timing of those impacts. Scientists' Inst. for Pub. Info., Inc. v. U.S. Atomic Energy Comm'n, 481 F.2d 1079, 1092 (D.C. Cir. 1973) (noting that the courts must therefore "reject any attempt by agencies to shirk their responsibilities under NEPA by labeling any and all discussion of future environmental effects as 'crystal ball inquiry"). See also Mid States Coal. for Progress v. Surface Transp. Bd., 345 F.3d 520, 549 (8th Cir. 2003) ("[W]hen the nature of the effect is reasonably foreseeable but its extent is not, we think that the agency may not simply ignore the effect."); City of Davis v. Coleman, 521 F.2d 661, 675 (9th Cir. 1975) ("The nature and extent of development which the project will induce is still uncertain. Davis' fears may be 


\section{c. LNG Export Terminals}

In 2016, the D.C. Circuit Court of Appeals issued three decisions involving the scope of the upstream and downstream emissions analysis for LNG export terminals. ${ }^{263}$ In all three cases, the court rejected claims that FERC should have considered upstream and downstream greenhouse gas emissions as part of its NEPA review. In particular, the court opined that FERC does not have to analyze the extent to which natural gas exports would induce additional natural gas production or the corresponding greenhouse gas emissions from induced production as indirect effects of the LNG terminal approvals, because DOE ultimately has authority over export decisions.

All three decisions were based on the unique set of circumstances involved in the approval of LNG exports. Decisions regarding the export of natural gas from the United States are split between two agencies: FERC and DOE. While FERC has jurisdiction over the siting, construction, and operation of LNG export terminals, DOE has the sole authority to license the export of any natural gas from those terminals, based either on its determination that such exports would serve the public interest or else on the public interest presumption given to free-trade agreement countries. ${ }^{264}$ Consistent with this division of responsibilities, the court held that FERC's NEPA analysis did not have to address the indirect effects of the anticipated export of natural gas. The court explained that Public Citizen was controlling in this case, because:

The Department's independent decision to allow exports—a decision over which the Commission has no regulatory authority—breaks the NEPA causal chain and absolves the Commission of responsibility to include in its NEPA analysis considerations that it "could not act on" and for which it cannot be "the legally relevant cause." 265

Importantly, the D.C. Circuit explained it was expressing no opinion on whether FERC's environmental analysis would have been adequate to satisfy DOE's independent NEPA obligation in authorizing the export of natural gas. ${ }^{266}$ The DOE's compliance with NEPA in the context of LNG facilities is

exaggerated. But currently available information and plain common sense indicate that it was hardly "reasonable" for CDHW or FHWA to conclude, without further study, that the environmental impact of the proposed interchange will be insignificant.").

263. Sierra Club v. Fed. Energy Regulatory Comm'n, 827 F.3d 59 (D.C. Cir. 2016); Sierra Club \& Galveston Baykeeper v. Fed. Energy Regulatory Comm'n, 827 F.3d 36 (D.C. Cir. 2016); EarthReports Inc. v. Fed. Energy Regulatory Comm'n, 828 F.3d 949 (D.C. Cir. 2016).

264. See DOE/FE Order No. 3784, supra note 45, at 2-4.

265. Galveston Baykeeper, 827 F.3d at 48 (citing Pub. Citizen v. U.S. Dep't of Transp., 541 U.S. 752,769 (2004)).

266. Id. at 45-46. See also Sierra Club, 827 F.3d at 69 ("Nothing in our opinion should be read to foreclose [the DOE] challenge or predetermine its outcome."). 
the subject of two other lawsuits, one challenging DOE's order authorizing the LNG exports at issue in one of these cases, ${ }^{267}$ and another challenging the DOE export approval for another such facility in Maryland. ${ }^{268}$ The D.C. Circuit noted that the plaintiffs should raise any objections related to the analysis of environmental impacts from LNG exports during those proceedings. ${ }^{269}$

In short, the three recent D.C. Circuit decisions on LNG export terminals do not settle questions on the scope of the indirect impact analysis for LNG exports in toto, nor do they directly contradict the key premise of this paper: that the federal government should, at some point in the decision-making chain for fossil fuel-related approvals, conduct an analysis of upstream and downstream emissions. The outcomes of the cases involving DOE's export authorizations will further clarify who, if anyone, is required to conduct such an analysis, and at what point along the decision-making chain.

Moreover, these decisions do not establish binding precedent for other types of fossil fuel-related approvals, such as pipeline approvals and leasing decisions. Arguably, these other types of approvals can more directly affect patterns of fossil fuel production and consumption (and corresponding emissions), ${ }^{270}$ and the reviewing agencies can then act on information about these effects when deciding whether and how to proceed with the proposed action. Requiring an upstream and downstream emissions analysis for such decisions is therefore consistent with Public Citizen v. Dept. of Transportation and the NEPA regulations.

\section{Future Directions in Indirect Effects Analysis}

There are two issues that remain to be settled regarding the proper scope of NEPA review for extraction projects: (1) under what circumstances are agencies required to disclose emissions from transportation and processing in the NEPA documents for extraction projects, and (2) what downstream emissions must be analyzed in NEPA documents for proposals involving oil and gas production?271 Presumably, agencies should be required to consider downstream

267. Sierra Club v. U.S. Dep't of Energy, No. 15-1489 (D.C. Cir. filed Dec. 22, 2015).

268. Sierra Club v. U.S. Dep't of Energy, No. 16-1186 (D.C. Cir. filed June 15, 2016).

269. Galveston Baykeeper, 827 F.3d at 40.

270. See generally Oil Change Int'l, A Bridge Too Far: How Appalachian Basin Gas Pipeline Expansion Will Undermine U.S. Climate Goals (2016) (explaining how pipeline development unlocks new gas reserves, thus leading to additional production).

271. As of September 2016, there are several pending cases that address these questions. See WildEarth Guardians v. Jewell, No. 1:16-cv-01724 (D.C. Cir. filed Aug. 25, 2016) (challenging failure to consider downstream emissions from oil and gas leasing); WildEarth Guardians v. Jewell, No. 1:15-cv-02026 (D. Colo. filed Sept. 15, 2015) (challenging approval of multiple mining plans in Colorado, New Mexico, Wyoming, and in particular, DOI's failure to consider downstream effects related to transport and combustion of coal); WildEarth Guardians v. Jewell, No. 15-cv-01984 (D. Colo. filed Sept. 11, 2015) (challeng- 
emissions from oil and gas production just as they would consider those emissions from coal production, and transportation and processing emissions should be included in calculations of downstream emissions whenever data and tools are available to estimate those emissions. ${ }^{272}$ Another outstanding question is whether the District Court of Wyoming's decision in WildEarth Guardians v. U.S. Forest Service will be overturned on appeal. ${ }^{273}$ As noted above, that is the only case upholding an agency's conclusion that coal leases do not increase emissions because an equivalent amount of coal would be mined and burned regardless of whether the leases are issued. ${ }^{274}$

The most critical context in which courts have not yet required an analysis of upstream or downstream emissions is the NEPA review of pipeline projects. ${ }^{275}$ (As discussed above, the D.C. Circuit has also concluded that no analysis is required for FERC's approval of LNG export terminals, but has not yet concluded that the NEPA review for LNG exports does not require such analysis). Notably, none of the three decisions that have been issued in this context includes an explanation of why pipelines should be treated differently

ing BLM/USFS approval of the Flat Canyon Coal Lease and failure to analyze greenhouse gas emissions from coal mining, transport, or combustion); Montana Elders v. Office of Surface Mining, Reclamation \& Enft, No. 9:15-cv-001016 (D. Mont. filed Aug. 17, 2015) (challenging approval of Bull Mountain Mine expansion in Montana, and the OSMRE's failure to take a hard look at the indirect and cumulative effects of coal transportation, coal exports, and coal combustion, plaintiffs note that combined greenhouse gas emissions from mine operations, coal transportation, and coal combustion would be approximately 23 million metric tons of $\mathrm{CO}_{2} \mathrm{e}$, more than the annual emissions of the largest single point source of greenhouse gas emissions in the United States); WildEarth Guardians v. Jewell, No. 14cv-00112 (D.N.M. filed Sept. 29, 2014) (same challenge, but for coal mine in New Mexico).

272. The Appendix contains a list of data resources and tools that can be used to estimate transportation emissions-however, there may be circumstances where transportation and processing emissions cannot be estimated due to uncertainty about, e.g., the mode and route of transportation.

273. WildEarth Guardians v. U.S. Bureau of Land Mgmt., Case No. 15-8109 (10th Cir. filed Oct. 9, 2015).

274. WildEarth Guardians v. U.S. Forest Serv., 120 F. Supp. 3d 1237, 1273 (D. Wyo. 2015).

275. At the time of this writing (Sept. 2016), there are at least four cases currently pending before the D.C. Circuit and the Second Circuit involving the obligation to consider upstream and downstream emissions from pipelines and LNG export terminals. One of these involves FERC's review of a LNG export terminal, and will thus likely be decided on the same grounds as the LNG export cases discussed above. But there is no controlling precedent dictating the outcome of the other three cases. Sierra Club v. U.S. Dep't of Energy, No. 161186 (D.C. Cir. filed June 15, 2016) (involving DOE export terminal approval); Catskill Mountainkeeper, Inc. v. Fed. Energy Regulatory Comm'n, No. 16-345 (2d Cir. filed Feb. 5, 2016) (involving FERC pipeline approval); Earthreports, Inc., Sierra Club, \& Chesapeake Climate Action Network v. Fed. Energy Regulatory Comm'n, No. 15-1127 (D.C. Cir. filed May 7, 2015) (involving FERC export terminal approval); Sierra Club v. U.S. Dep't of Energy, No. 15-1489 (D.C. Cir. filed Dec. 22, 2015) (involving DOE export terminal approval). 
than coal rail lines, or why the "perfect substitution" argument should be accepted in this context but not the context of coal extraction and transportation. Moreover, those decisions are not necessarily determinative of future outcomes. In the first case, South Coast Air Quality Management District v. FERC, the court found that FERC had already conceded that the pipeline would "substantially increase" $\mathrm{NO}_{\mathrm{x}}$ emissions from combustion and implemented a mitigation measure to control those emissions, and thus it need not determine whether NEPA required such analysis. ${ }^{276}$ The court's analysis in the second case, Sierra Club v. Clinton, was entirely dependent on the record before it. ${ }^{277}$ Applying the same principles, but provided with evidence that the pipeline would induce additional oil or gas development, a court could reach the opposite conclusion about the agency's obligation to evaluate upstream emissions. Finally, Coalition for Responsible Growth was a summary opinion of no precedential effect which contains almost no legal analysis, and does little to inform our discussion of whether and to what extent agencies must evaluate upstream and downstream emissions from pipelines. ${ }^{278}$

There is good reason for the courts to require analysis of upstream and downstream emissions for both pipelines and LNG exports. The underlying justification for pipelines is to provide the capacity necessary to transport additional quantities of oil or gas to market, as compared with what can be transported via existing infrastructure. Even if the pipeline will not increase the rate of production over a historical baseline, it will allow for the continued supply of the resource (and thus production will be higher than it would have been if the pipeline were not constructed). ${ }^{279}$ If this was not the case, then there would be no need for the project, and thus no reason to issue a certificate of public convenience and necessity. The bottom line is that FERC and other agencies cannot have it both ways: the pipeline is either needed to transport additional quantities of natural gas to markets, in which case it will enable additional production and consumption of gas, or the project is unnecessary.

Recent studies support the proposition that induced oil and gas production consumption are foreseeable effects of pipeline construction. ${ }^{280}$ Two of the key

276. S. Coast Air Quality Mgmt. Dist. v. Fed. Energy Regulatory Comm'n, 621 F.3d 1085, 1093-95 (9th Cir. 2010).

277. Sierra Club v. Clinton, 746 F. Supp. 2d 1025 (D. Minn. 2010).

278. Coal. for Responsible Growth \& Res. Conservation v. Fed. Energy Regulatory Comm'n, 485 F. App'x 472, 474 (2d Cir. 2012).

279. As noted above, courts have rejected the idea that actions which prolong the supply of resources without increasing the rate of supply are merely a continuation of the "status quo." Agencies must account for the environmental impacts that occur as a result of the prolonged production and consumption of the resource. See supra Part IV.B.1.a.

280. See, e.g., Oil Change Int'l, A Bridge Too Far: How Appalachian Basin Gas Pipeline Expansion Will Undermine U.S. Climate Goals (2016) (explaining how pipeline development unlocks new gas reserves, thus leading to additional production); NAT'L Energy Bd., Canada's Energy Future 2016: Energy Supply and Demand Projec- 
findings from these studies include: (1) the construction of pipelines provides access to new oil and gas reserves that would not have otherwise been economical to develop, and (2) the construction of pipelines increases the profit margins for oil and gas, thus increasing investment in and production of these resources. ${ }^{281}$ These studies support one of the key findings from the Eighth Circuit Court of Appeals in Mid States Coalition for Progress: the idea that a project intended to transport fossil fuels will have no effect on their consumption is "illogical at best" because the project will affect the price and profitability of the resource vis-à-vis other energy sources. ${ }^{282}$

There are also a number of studies showing that LNG exports will increase natural gas demand, production, and consumption. ${ }^{283}$ DOE itself has recognized that LNG exports would be offset, at least in part, by increased domestic production of natural gas, primarily from unconventional sources, as well as decreased domestic consumption. ${ }^{284}$ Given that DOE has already recognized these potential effects and has access to lifecycle assessments and other tools to model emissions, ${ }^{285}$ there is no reason that it should not consider these when reviewing the environmental impacts of LNG exports. ${ }^{286}$ In particular, plaintiffs in one of the pending Sierra Club v. DOE cases have argued that DOE needs to take a closer look at: (1) GHG emissions from natural gas pro-

TIONS TO 2040 (2016) (finding that oil production and GHG emissions would be lower if oil pipelines are not constructed, because reliance on more costly forms of transportation such as rail and competition for pipeline capacity will reduce the profitability of oil, thus reducing oil production and use and the corresponding GHG emissions).

281. Id.

282. Mid States Coal. for Progress v. Surface Transp. Bd., 345 F.3d 520, 549 (8th Cir. 2003).

283. See, e.g., ICF Int'l, State-Level Impacts on Energy Markets and the Economy (2013), attached as Exhibit 12 to Sierra Club Comment on Draft EIS ("ICF"s original modeling showed that for each of the three export cases, the majority of the incremental LNG exports (79\%-88\%) are offset by increased domestic natural gas production."); U.S. ENERGY INFO. AdMIN., Effect of Increased Natural Gas Exports on Domestic Energy Markets (2012) ("EIA LNG Export Study") (natural gas exports would be offset by increased production); Seksun Moryadee et al., Investigating the Potential Effects of U.S. LNG Exports on Global Natural Gas Markets, 2(3) Energy Strategy Reviews 273 (2014) (finding that "U.S. domestic natural gas prices [would] increase approximately $10.9 \%$ given 123 billion cubic meters of LNG exports, and that natural gas prices in Europe and Asia would decrease significantly").

284. U.S. Dep't of Energy, Addendum to Environmental Review Documents ConCerning Exports of Natural Gas from the United States (2014) ("LNG export volumes would be offset by some combination of increased domestic production of natural gas (principally from unconventional sources), decreased domestic consumption of natural gas, and an adjustment to the U.S. net trade balance in natural gas with Canada and Mexico.").

285. See infra Appendix.

286. Note that DOE would only be conducting this review in the context of LNG exports to countries without FTA status. As noted in Part I.B, LNG exports to countries with FTA status are automatically deemed to be in the public interest. 
duction, transport and processing, (2) GHG emissions from a foreseeable increase in domestic coal consumption that may occur due to a decline in domestic natural gas consumption, and (3) GHG emissions from any foreseeable changes in international energy consumption. ${ }^{287}$

If the courts ultimately hold that an analysis of upstream and/or downstream emissions are not required in the context of pipelines and/or export approvals, it will be important to explain precisely why natural gas pipelines should be treated differently than coal rail lines and extraction projects. It will also be important for the D.C. Circuit to explain who will assess the climate impacts of natural gas that is extracted from private lands, if not FERC or DOE. What is critically important is that the federal government does, at some point in the supply chain, conduct a comprehensive analysis of greenhouse gas emissions for natural gas that is transported via federally approved pipelines and export terminals. As discussed in our recommendations, a programmatic review of pipelines and export terminals would likely be the best way to conduct this analysis.

\section{Effects of Related Actions}

As noted in Part IV.B.3, just above, there is some overlap between the concept of "indirect impacts" and the "impacts of related actions" that must be reviewed under NEPA. Specifically, upstream and downstream emissions may also be conceptualized as the effects of "related actions" when such emissions occur as a result of other federal approvals in the fossil fuel supply chain that must also undergo NEPA review.

If a court concludes that such emissions should be evaluated as indirect effects, it may conclude that it is neither necessary nor prudent to determine whether those emissions also constitute the effects of a connected action (since this would entail issuing a much broader holding which requires the agency to evaluate all reasonably foreseeable effects of the related actions). ${ }^{288}$ But if a court concludes that certain upstream or downstream emissions are not indirect impacts, then the requirement to evaluate the impacts of related actions provides an alternate basis for concluding that an agency must evaluate upstream and/or downstream emissions in its NEPA review.

287. See Proof Opening Brief for the Petitioner at 60-63, 71-76, Sierra Club v. U.S. Dep't of Energy, No. 15-1489 (D.C. Cir. Mar. 21, 2016).

288. See Valley Forge Ins. Co. v. Health Care Mgmt. Partners, Ltd., 616 F.3d 1086, 1094 (10th Cir. 2010) ("Judicial restraint ... means answering only the questions we must, not those we can.”); Diné Citizens Against Ruining Our Env't v. Office of Surface Mining, Reclamation \& Enf t, 82 F. Supp. 3d 1201, 1212 (D. Colo. 2015), appeal dismissed (Mar. 2, 2015) ("Because I conclude that the combustion-related impacts are 'indirect effects of the proposed action,' I find it unnecessary to reach the parties' arguments relating to whether or not the continued operation of the Four Corners Power Plant is a 'connected action.'”). 
This requirement to evaluate related actions in a single NEPA review is often referred to as a rule prohibiting the "segmentation" of actions and their environmental impacts. As noted by the D.C. Circuit Court of Appeals, "[t]he justification for the rule against segmentation is obvious: it prevent [s] agencies from dividing one project into multiple individual actions each of which individually has an insignificant environmental impact, but which collectively have a substantial impact." ${ }^{289}$ Similarly, the Ninth Circuit has noted that the purpose of NEPA "cannot be fully served if consideration of the cumulative effects of successive, interdependent steps is delayed until the first step has already been taken." 290

The regulations identify three types of related actions that may warrant consideration in a single NEPA review: related actions, cumulative actions, and similar actions. This section will briefly review the case law on each type of action and how the judicial standards might be applied in the context of fossil fuel-related approvals.

\section{Connected Actions}

The NEPA regulations specify that agencies should conduct a joint review of connected actions, which are "closely related and therefore should be discussed in the same impact statements." ${ }^{291}$ These include actions that "automatically trigger" other actions which may require EISs, actions that "[c]annot or will not proceed unless other actions are taken previously or simultaneously," and actions that are "interdependent parts of a larger action and depend on the larger action for their justification." ${ }^{292}$ Courts have interpreted these regulations as imposing a mandatory obligation on agencies to conduct a joint review of actions that either have no independent purpose or utility ${ }^{293}$ or "the dependency is such that it would be irrational, or at least unwise" to undertake one action if the other(s) were not also undertaken..$^{294}$

Courts will frequently find that two actions are connected when one action involves the development of access roads or other infrastructure that are necessary to proceed with the other action. In Thomas v. Peterson, a Ninth Circuit case from 1985, the construction of a timber access road and the approval of a timber harvest were connected actions that must be reviewed together, because "it would be irrational to build the road and then not sell the timber to which

289. Del. Riverkeeper Network v. Fed. Energy Regulatory Comm'n, 753 F.3d 1304, 1314 (D.C. Cir. 2014) (citing Nat. Res. Def. Council v. Hodel, 865 F.2d 288, 297 (D.C. Cir. 1988) (internal quotation marks omitted)).

290. Thomas v. Peterson, 753 F.2d 754, 760 (9th Cir. 1985).

291. 40 C.F.R. § 1508.25(a)(1) (2016).

292. Id.

293. Custer Cty. Action Ass'n v. Garvey, 256 F.3d 1024, 1037 (10th Cir. 2001).

294. Trout Unlimited v. Morton, 509 F.2d 1276, 1285 (9th Cir. 1974). 
the road was built to provide access." ${ }^{295}$ Notably, the court rejected USFS's argument that "sales are too uncertain and too far in the future for their impacts to be analyzed along with that of the road," noting that "[ $t]$ his comes close to saying that building the road now is itself irrational . ... if the sales are sufficiently certain to justify construction of the road, then they are sufficiently certain for their environmental impacts to be analyzed along with those of the road." ${ }^{296}$ Similarly, in Sierra Club v. United States, a federal district court in Colorado found that a proposed easement for a mine access road and the operation of a mine were connected actions because they were "inextricably linked." 297 "But for the road, the mining company could not access the mine site; absent the mine, there is no independent utility for the access road." 298

Connected actions may also include activities that are part of a larger whole. For example, in Blue Ocean Preservation Society v. Watkins, the district court in Hawaii held that four phases of geothermal energy development were sufficiently connected to require evaluation in the same EIS. The four stages were: (1) a geothermal resource assessment program, (2) a deep water cable program, (3) a geothermal verification and characterization program, and (4) construction of a geothermal plant. The court held that the first three stages lacked independent utility, were all intended to support the final phase of the project, and were therefore "connected actions" within the meaning of NEPA. ${ }^{299}$

Most notably for the purposes of this Article, in Delaware Riverkeeper Network v. FERC, the D.C. Circuit held that four segments of a pipeline project were connected actions because they were physically connected, they were being constructed in relatively the same time period, and they lacked independent utility. ${ }^{300}$ In contrast, the Tenth Circuit in Wilderness Workshop v. U.S. Bureau of Land Management concluded that the authorization of a natural gas pipeline and "future natural gas development" were not connected actions within the meaning of NEPA, because there was no imminent government action to develop natural gas resources that would also require an EIS. ${ }^{301}$ (Notably, the

\footnotetext{
295. Thomas v. Peterson, 753 F.2d 754, 759 (9th Cir. 1985).
}

296. Id. at 760. See also Save the Yaak Comm. v. Block, 840 F.2d 714, 719-20 (9th Cir. 1988) (finding that road reconstruction and timber harvest were connected actions within the meaning of section 1508.25(a)(1)); Alpine Lakes Prot. Soc'y v. U.S. Forest Serv., 838 F. Supp. 478, 482 (W.D. Wash. 1993) (access road permit and timber management activities were connected actions).

297. Sierra Club v. United States, 255 F. Supp. 2d 1177, 1184 (D. Colo. 2002).

298. Id.

299. Blue Ocean Pres. Soc'y v. Watkins, 754 F. Supp. 1450, 1459 (D. Haw. 1991).

300. Del. Riverkeeper Network v. Fed. Energy Regulatory Comm'n, 753 F.3d 1304, 1308-09 (D.C. Cir. 2014).

301. Wilderness Workshop v. U.S. Bureau of Land Mgmt., 531 F.3d 1220, 1221 (10th Cir. 2008) 
decision in Wilderness Workshop did not discuss whether the effects of future natural gas development should be discussed as indirect or cumulative impacts).

Applying these standards, one could argue that various phases of fossil fuel development are "connected actions" that require a programmatic EA or EIS if there are multiple approvals that trigger NEPA review occurring during roughly the same period. This argument could be made even in the context of different types of approvals conducted by different agencies-for example, the approval of a coal lease or mining plan and the approval of a rail line that would service those mines may constitute "connected actions" that lack independent utility and should thus be reviewed in a single NEPA document. ${ }^{302}$ However, if otherwise connected activities are not federal actions subject to NEPA, then the proper approach would be to analyze the emissions from non-federal activities as indirect effects of a federal action. It may also be the case that there are multiple federal approvals involved but these approvals will occur at different times, making it difficult or impossible for an agency to evaluate them in the same EA or EIS. In that case, it would also make sense to discuss potential emissions from future stages of fossil fuel development as indirect effects that may occur further down the road.

\section{Cumulative Actions}

The NEPA regulations also require a joint review of federal actions that "have cumulatively significant impacts and should therefore be discussed in the same impact statement." 303 This is distinct from the requirement to review the "cumulative effects" of a single action, which entails an assessment of "the incremental impact of the action when added to other past, present, and reasonably foreseeable future actions," regardless of whether these actions are undertaken by a governmental or non-governmental actions. ${ }^{304}$ The circumstances under which an agency must evaluate cumulative actions in the same EIS or EA are narrower-this requirement only applies when there are two or more federal "actions" subject to NEPA with cumulative effects—but the scope of the analysis is broader-the agency must conduct a complete review for each of the cumulative actions.

The cases in which courts have compelled consideration of cumulative actions in a single EA or EIS typically involve actions that have something in common-e.g., they are very similar actions or they are part of integrated infrastructure. For example, in N. Cascades Conservation Council v. U.S. Forest Serv., three off-road vehicle trail construction projects were considered cumulative ac-

302. There is a clear analogy to the cases involving access roads and connected activities-but for the rail line, the mining company could not transport its coal to end users or markets; absent the mine, there is no independent utility to the rail line.

303. 40 C.F.R. $\S 1508.25(\mathrm{a})(2)$ (2016).

304. 40 C.F.R. $\S 1508.7$. 
tions that must be evaluated in the same EA. A district court in Washington explained that these were not connected actions, because "the success or failure of one or all of the projects is not dependent upon the completion of the others" but they were part of a larger trail system with cumulatively significant effects and thus met the regulatory definition for "cumulative actions." ${ }^{05}$ Similarly, in Alpine Lakes Protection Society v. USFS, permit applications for seven access roads in the same region were considered cumulative actions. ${ }^{306}$ Finally, in Blue Mountains Biodiversity Project v. Blackwood, the Ninth Circuit concluded that multiple salvage logging projects that would affect the same region were cumulative actions. There, the court noted that a joint review should be conducted when the record raises "substantial questions" about whether there will be "significant environmental impacts" from the projects when reviewed in the aggregate. ${ }^{307}$

In the seminal case of Kleppe v. Sierra Club, the Supreme Court explained how this requirement would apply to multiple decisions about leasing coal from federal lands:

A comprehensive impact statement may be necessary in some cases for an agency to meet [its duty to evaluate environmental impacts]. Thus, when several proposals for coal-related actions that will have cumulative or synergistic environmental impact upon a region are pending concurrently before an agency, their environmental consequences must be considered together. Only through comprehensive consideration of pending proposals can the agency evaluate different courses of action. ${ }^{308}$

In that case, the court ultimately deferred to the federal government's decisions about how to go about conducting programmatic reviews of coal mining, and in particular the government's decision that "the appropriate scope of comprehensive statements should be based on basins, drainage areas, and other factors." ${ }^{309}$ Based on these factors, it held that the federal government's decision not to prepare a PEIS for the entire Great Plains Region was acceptable. But the court's description of the basic rationale of programmatic reviews remains rele-

305. N. Cascades Conservation Council v. U.S. Forest Serv., 98 F. Supp. 2d 1193, 1199 (W.D. Wash. 1999) (internal quotations omitted).

306. Alpine Lakes Prot. Soc'y v. U.S. Forest Serv., 838 F. Supp. 478, 484 (W.D. Wash. 1993) ("The failure to even consider whether there is a potential for cumulative impact on any aspect of the environment except wildlife species as a result of these projects cannot be characterized as a 'truly informed exercise of discretion,' nor can it be said to amount to the requisite 'hard look' at the environmental consequences of granting the permits in question.").

307. Blue Mountains Biodiversity Project v. Blackwood, 161 F.3d 1208, 1212 (9th Cir. 1998).

308. Kleppe v. Sierra Club, 427 U.S. 390, 409-410 (1976) (citations omitted).

309. Id. at $413-14$. 
vant-NEPA requires comprehensive environmental reviews that account for the cumulative and synergistic environmental impacts on a particular resource, and in the context of global climate change, that resource is the global atmosphere.

Courts may also defer to an agency's decision not to conduct a joint EIS for approvals that do not occur in the same time frame. For example, in Klamath-Siskiyou Wildlands Ctr. v. Bureau of Land Mgmt., the court held that four timber sales that would potentially have cumulative effects on the landscape did not require a single EIS, because the approvals were scheduled to occur incrementally, instead of being approved together simultaneously. Due to uncertainties about the future approvals, the court held that it was appropriate to defer to BLM's judgment about whether to prepare a single EIS. ${ }^{310}$

Any federal decision that authorizes the extraction or transportation of fossil fuels could be viewed as having a cumulatively significant effect on greenhouse gas emissions, and thus these decisions could qualify as "cumulative actions" requiring a joint NEPA review if they are scheduled to occur during approximately the same time frame. However, courts have only enforced this requirement in the context of projects that are similar in nature and located in the same geographic region. There is not yet any case law on how this requirement might be interpreted in the context of similarly situated projects with cumulatively significant greenhouse gas emissions, but it is possible that they would depart from the focus on geographic proximity (since this is irrelevant in the context of fossil fuels). Moreover, there is not a well-established threshold for what constitutes "significant" greenhouse gas emissions in the context of NEPA reviews. Agencies almost never conclude that greenhouse gas emissions are significant, but they do frequently state that such emissions are insignificant because they represent only a small portion of U.S. or total emissions. ${ }^{311}$ In its final guidance, CEQ has stated that such statements are not helpful, but CEQ has not specified a significance threshold for greenhouse gas emissions. ${ }^{312}$

\section{Similar Actions}

Those advocating for a more comprehensive review of greenhouse gas emissions from fossil fuel-related approvals might also refer to the regulatory provisions calling for joint analysis of "similar actions" to support their position. The NEPA regulations specify that an agency "may wish" to analyze "similar actions" in the same NEPA document-similar actions being defined as those which "have similarities that provide a basis for evaluating their environmental

310. Klamath-Siskiyou Wildlands Ctr. v. U.S. Bureau of Land Mgmt., 387 F.3d 989, 1000 (9th Cir. 2004).

311. See Wentz ET AL., supra note 21, at 7.

312. Final CEQ Guidance, supra note 16, at 11. 
consequences together, such as common timing or geography." The regulations further note that an agency "should do so when the best way to assess adequately the combined impacts of similar actions or reasonable alternative to such actions is to treat them in a single impact statement." 313

The "similar actions" provision does not directly support the idea that an agency should evaluate upstream and downstream emissions (since different phases of the fossil fuel supply chain would not necessarily constitute "similar actions") but it does support the idea that agencies should conduct programmatic reviews of similar actions, such as fossil fuel leasing decisions or pipeline approvals, when that is the best way to adequately assess the combined impacts of these projects.

However, the courts have concluded that this language does not impose a clear mandate on agencies to evaluate similar actions in a single EA or EIS. The Ninth Circuit has explained:

"For the first two categories [connected and cumulative actions], the agency is told that it "should" analyze them in a single impact statement, which we interpret as a mandatory requirement. For "similar" actions, on the other hand, we held that an agency should be accorded more deference in deciding whether to analyze such actions together." 314

Thus, courts generally defer to an agency's decision about how to evaluate similar actions. ${ }^{315}$

Thus, in light of the deference shown to agencies, it is unlikely that this provision could be used to compel a programmatic review of similar fossil fuel projects. But agencies can certainly refer to this provision to justify decisions to evaluate similar projects in the same EIS or EA.

\section{Concluding Remarks on Related Actions}

The case law on related actions suggests that there are circumstances in which the requirements to evaluate "connected" and "cumulative" actions together could be used to compel the preparation of a joint or programmatic NEPA review to evaluate a broader scope of greenhouse gas emissions associated with the development of fossil fuels. But these requirements only apply when there are two or more federal actions occurring simultaneously_other-

313. 40 C.F.R. § 1508.25(a)(3) (2016).

314. Klamath-Siskiyou Wildlands Ctr., 387 F.3d at 1001 (citing Earth Island Inst. v. U.S. Forest Serv., 351 F.3d 1291 (9th Cir. 2003)).

315. Earth Island Inst., 351 F.3d at 1306 (USFS not required to evaluate two fire-restoration projects as similar actions); Klamath-Siskiyou Wildlands Ctr., 387 F.3d at 1001 (BLM not required to evaluate four timber sales as similar actions in same EIS, despite many similarities). 
wise, it makes more sense to rely on the indirect effects requirement to compel consideration of upstream and downstream emissions. There is also a good chance that courts will defer to agency decisions about when and how to prepare programmatic EISs for coal, oil, and gas development, except in circumstances where the segmentation of the NEPA review is so obvious and egregious that the agency cannot provide any reasonable explanation for its decision. FERC's decision to conduct separate NEPA reviews for different segments of a natural gas pipeline is one example of such a situation. But if an agency is reviewing proposals that are not physically connected (e.g., coal mining applications) or that are different in nature (e.g., a coal mining application and a coal railway), the courts may very well defer to the agency's decision about how to structure the NEPA review process.

Due to the difficulties of obtaining a court order compelling the federal government to prepare a comprehensive programmatic EIS for fossil fuel leasing and infrastructure programs, many groups are attempting to use political channels to persuade the government to prepare these documents. As discussed above, the federal government has already agreed to conduct a programmatic review of the federal coal leasing program, and this decision was largely driven by engagement with public stakeholders who were concerned about the environmental and social effects of the coal leasing program. ${ }^{316}$ Environmental groups are now calling for a programmatic review of pipeline infrastructure and LNG export terminals. ${ }^{317}$ But FERC has explicitly declined to conduct such a review, ${ }^{318}$ and DOE has thus far ignored the requests.

\section{Recommendations}

Federal agencies can improve the informational basis for their decisionmaking and improve their chances in litigation by incorporating projections of upstream and downstream greenhouse gas emissions in the EISs and EAs prepared for fossil fuel management decisions. These recommendations describe how a federal agency can conduct a greenhouse gas assessment that will satisfy the requirements of NEPA and provide useful information for decision-makers

316. U.S. Dep't. of Interior, Order No. 3338, Discretionary Programmatic Environmental Statement to Modernize the Federal Coal Program 3 (Jan. 15, 2016).

317. See, e.g., Nat. Res. Def. Council, Motion to Intervene, Initial Comments, and Request for Programmatic Environmental Impact Statement, Fed. Energy Regulatory Comm'n Docket No. CP16-21-000 (Apr. 28, 2016), https://perma.cc/E3SM-FHJ4; Sierra Club, Motion to Intervene, Protest, and Comments, FE Docket No. 14-88-LNG (Jan. 9, 2015), https:// perma.cc/T7AQ-YUP3; Letter from 30 Environmental Groups to the Federal Energy Regulatory Commission (Oct. 26, 2015), https://perma.cc/9ML8-83D4.

318. See, e.g., Corpus Christi Liquefaction LLC \& Cheniere Corpus Christi Pipeline L.P., 151 FERC 91,098 , at 27 (2015) (declining to conduct a programmatic NEPA review of CCL Project); Sabine Pass Liquefaction Expansion, LLC, Order Denying Rehearing, 151 FERC \ 61,253, at \ 40 (2015). 
and the public. They could also be used as a guide for advocates and courts to establish how federal agencies can and should evaluate greenhouse gas emissions in the context of these projects.

One threshold recommendation is that the most efficient and comprehensive way to conduct the emissions analysis for fossil fuel leasing decisions and transportation projects would be through the preparation of programmatic EISs, like that which is currently being prepared for the federal coal leasing program. Specifically, the federal government should also consider conducting programmatic reviews for oil and gas leasing, natural gas pipelines, and LNG exports. The programmatic EIS for each of these program areas could serve two purposes: First, it would enable decision-makers to consider the effects of leasing and infrastructure projects across the entire country, rather than on a project-by-project basis. This would facilitate more rational planning with regards to the number and scale of any future leases, pipelines, and other projects that can be approved without undermining our ability to achieve greenhouse gas reduction targets. Second, the programmatic EIS could be used to establish specific indicators or metrics for evaluating specific projects. These could include metrics for estimating upstream and downstream greenhouse gas emissions (e.g., standardized metrics for estimating emissions from end uses of different fossil fuels), as well as measures to ensure new infrastructure is consistent with climate policies and greenhouse gas targets (e.g., a cap on the amount of federal coal that can be produced in the coming decades, which would then be used to determine whether the issuance of a new lease or extension of an existing lease can be approved). Until such programmatic reviews are conducted for all types of actions, federal agencies can refer to the following recommendations for guidance on how to address upstream and downstream emissions on a project-specific basis.

\section{A. Fossil Fuel Extraction}

When preparing an EIS or EA for any federal action that involves the extraction of fossil fuels, the agency should acknowledge that downstream emissions from the transportation, processing and combustion of the resource are indirect effects of the action. If it is possible to estimate the amount of the resource that may be extracted, then the agency's disclosure of downstream emissions should be quantified. At minimum, the agency should estimate downstream emissions from combustion by multiplying the amount of the resource to be extracted by the $\mathrm{CO}_{2}$ emission factor for the fuel. ${ }^{319}$ The agency can refer to the resources described in the Appendix to conduct a more detailed analysis of end use emissions that accounts for different combustion technologies and non-combustion applications.

319. See U.S. Energy Info. Admin., Electric Power Annual 2014, app. tbl.A.3 (2016). 
The resources in the Appendix can also be used to estimate emissions from the transportation and processing of the resource. If the precise route or method is unknown, the agency should refer to national or regional averages in order to forecast potential emissions from transportation and processing. For example, the agency can refer to the estimates of average life-cycle emissions for various U.S. fossil fuels to provide decision-makers and the public with a reasonable estimate of potential direct and indirect greenhouse gas emissions, accompanied by a qualitative explanation of how the actual emissions for the proposed action may differ from these averages. The agency can also use a range of estimates to account for uncertainty in this analysis. To the extent possible, the emissions inventory should specify the amount of emissions from different activities within the supply chain, as well as total direct and indirect emissions (see Table, below). It should also specify both annual emissions and total emissions over the lifetime of the project. It should also include emissions from activities that occur in other jurisdictions. ${ }^{320}$

\section{Table: Example Greenhouse Gas Emissions Inventory FOR OIL AND GAS LEASING ${ }^{321}$}

\begin{tabular}{|l|l|}
\hline $\begin{array}{l}\text { Oil \& Gas Activity } \\
\text { (based on 30 wells) }\end{array}$ & $\begin{array}{l}\text { Estimated Emissions } \\
\text { (Metric Tons } \mathbf{C O}_{2} \mathbf{e} \text { ) }\end{array}$ \\
\hline EXPLORATION & 7,495 \\
\hline PRODUCTION & 58,214 \\
\hline TRANSPORTATION OF CRUDE & 2,161 \\
\hline REFINING & 28,286 \\
\hline TRANSPORTATION OF REFINED & 868 \\
\hline PRODUCT END USE & 268,312 \\
\hline TOTAL & $\mathbf{3 6 5 , 3 3 6}$ \\
\hline
\end{tabular}

The inventory should be accompanied by an explanation of what each activity entails, and what assumptions underpin the greenhouse gas emission estimates (e.g., for end use estimates, the agency should specify the amount of fossil fuel to be produced and the emissions factor or other protocol used to calculate the emissions from combustion and other end uses).

This inventory of downstream greenhouse gas emissions could be supplemented by a market analysis of how the predicted increase in the supply of fossil fuels will affect prices and consumption vis-à-vis alternative fuel

320. It would be illogical to ignore greenhouse gas emissions in other jurisdictions, since a ton of $\mathrm{CO}_{2} \mathrm{e}$ has the same effect regardless of where it is emitted.

321. Adapted from: U.S. Forest Serv., Record of Decision and Final Environmental Impact Statement, Oil and Gas Leasing Analysis, Fishlake National Forest 169 (Table 3.12-7) (2013). 
sources - the goal being to develop an estimate of the net emissions of the project as compared with a no action alternative. A more complete discussion of whether and how such a market analysis should be performed is provided below.

Finally, after compiling a complete inventory of greenhouse gas emissions, the agency should consider how these emissions will interfere with (or help to achieve) $)^{322}$ national and state climate goals, consistent with their obligations under the NEPA implementing regulations. ${ }^{323}$ If the agency is conducting a cost-benefit analysis, it should also assign a value to greenhouse gas emissions using the federal social cost of carbon protocol, ${ }^{324}$ and the values used by the federal government to calculate the social costs of methane and nitrous oxide. ${ }^{325}$ Even in the absence of a full cost-benefit analysis, estimating the social costs of greenhouse gas emissions can be a helpful disclosure tool, because dollar estimates can give decision-makers and the public a better sense of the scale of the emissions impact.

\section{B. Fossil Fuel Transportation Infrastructure}

When preparing an EIS or EA for any infrastructure intended to transport fossil fuels, the agency should acknowledge that the indirect effects of the pro-

322. It is possible that projects aimed at promoting natural gas production will actually facilitate the attainment of greenhouse gas reduction targets, but the federal agency would need to verify this conclusion through technical analysis, rather than simply assuming this outcome.

323. See 40 C.F.R. $\S 1502.16$ (c) (2016) (requiring disclosure of "[p]ossible conflicts between the proposed action and the objectives of federal, regional, state, and local . . land use plans, policies, and controls"); 40 C.F.R. $§ 1506.2$ (d) (requiring that statements, when inconsistent with state or local plans, "should describe the extent to which the agency would reconcile its proposed action with the plan or law"). See also Revised Draft Guidance, supra note 18, at 77,826 (instructing agencies to provide a frame of reference for decision-makers by disclosing the extent to which greenhouse gas emissions are consistent with the goals of federal, state, tribal and local climate change policies).

324. The Social Cost of Carbon, EPA, https://perma.cc/L6QD-W6RB. See also Ctr. for Biological Diversity v. Nat'l Highway Traffic Safety Admin., 538 F.3d 1172, 1217 (9th Cir. 2008) (holding that NEPA requires agencies to analyze the effects of its actions on global climate change); High Country Conservation Advocates v. U.S. Forest Serv., 52 F. Supp. 3d 1174, 1193 (D. Colo. 2014) (requiring agency to use social cost of carbon protocol when calculating costs and benefits of action that would generate greenhouse gas emissions).

325. For the values currently utilized by EPA to calculate the social cost of methane and nitrous oxide emissions, see Alex L. Marten et al., Incremental $\mathrm{CH}_{4}$ and $\mathrm{N}_{2} \mathrm{O}$ Mitigation Benefits Consistent with the US Government's SC-CO 2 estimates, 15 Climate Pol'y 272 (2015). This toll has been used by EPA in previous rulemakings. See EPA, REgulatory IMPACt Analysis for the Proposed Revisions to the Emission Guidelines for Existing Sources and Supplemental Proposed New Source Performance Standards in the Municipal Solid Waste Landfills Sector 4-10 to 4-14 (2015); EPA, Regulatory Impact Analysis of the Proposed Emission Standards for New and Modified Sources in the Oil and Natural Gas Sector 4-14 (2015). 
ject will include upstream and downstream emissions from the production, processing, and consumption of the resource (and in some instances, from other stages of transportation). When the amount of fossil fuels that will be transported by the proposed infrastructure has been estimated, the agency should also include quantitative estimates of upstream and downstream emissions in its greenhouse gas emissions inventory. In other words, the inventory should include a lifecycle assessment of greenhouse gas emissions from the transported fuel. The inventory should be broken down into emissions from different activities within the supply chain, it should specify both annual emissions and total emissions over the lifetime of the project, and it should include emissions from activities in other jurisdictions.

The agency can refer to the resources in the Appendix to obtain estimates of average lifecycle emissions for different fuel sources in different contexts (e.g., lifecycle emissions for natural gas exports). If the agency believes that the average emissions estimates from other studies are not indicative of the emissions that would occur in the context of the particular action being reviewed, perhaps due to differences in the location of extraction, transportation route or the potential end use, the agency can either conduct its own quantitative emissions assessment, or cite the figures from other studies and provide a qualitative explanation of how emissions may differ for this particular project. Such an analysis would be more helpful to decision-makers and the public than, for example, a statement that upstream and downstream emissions are impossible to quantify as a result of uncertainties.

As with extraction projects, the agency may consider conducting a market analysis to determine the net emissions impact of the pipeline. The agency should also evaluate consistency with federal, tribal, state and local climate policies, and use the appropriate tools to assign a value to greenhouse gas emissions in any cost benefit analysis.

\section{Net Emissions Analysis}

Inventories of upstream and downstream greenhouse gas emissions can be supplemented by a "net emissions" analysis. This entails examining how the project will affect the supply and consumption of other energy sources in order to determine the incremental emissions impact of the project as compared with a no action alternative. It is important to note that, while courts have held that an agency must, at minimum, consider incremental emissions of this nature, ${ }^{326}$ they have not specifically held that it is improper to include the gross calculation of upstream and downstream emissions in the total estimate of indirect emissions.

326. Mid States Coal. for Progress v. Surface Transp. Bd., 345 F.3d 520, 549 (8th Cir. 2003); High Country Conservation Advocates, 52 F. Supp. 3d at 1198. 
There is a rational basis for treating all upstream and downstream emissions as the indirect effects of a project. A recent report from the Stockholm Energy Institute ("SEI") describes this as a "literalist" approach to emissions inventorying due to its specific focus on logic: because of a given project, a certain amount of fuel will be produced, transported, processed, and consumed, and this will generate a certain quantity of greenhouse gas emissions. ${ }^{327}$ The "literalist" approach accounts for the greenhouse gas impact of the fuel handled by the project without considering how the project affects broader energy markets - as such, it may be viewed as only a partial analysis of the greenhouse gas impact. However, the SEI report also notes that the "economist" approachwhich strives to identify the net emissions impact by considering effects on energy markets-requires decision-makers to "make assumptions about longterm economic responses that are difficult to assess." 328 Indeed, because of the assumptions and modeling that are required, the net impact analysis is both resource-intensive and easily manipulated. For these reasons, courts may hold that it is indeed appropriate for an agency to take a "literalist" approach when preparing an indirect emissions inventory.

If an agency does conduct a net emissions analysis for a particular action, it should be accompanied by a complete inventory of the action's gross upstream and/or downstream emissions, as described above. This inventory should be disclosed because: (i) it is the starting point for the net emissions analysis, (ii) it provides an alternate way of assessing the project's greenhouse gas impact; and (iii) it is less easily manipulated than the results of the net emissions analysis. The agency should also clearly disclose all of the data inputs, assumptions, and calculations used to determine net emissions.

There is also a need for overarching federal guidance should agencies continue to use the "economist" approach to evaluating upstream and downstream emissions. Having each agency conduct this analysis on a project-by-project basis, using different tools and data sources, would lead to inefficiencies and inconsistencies across different projects. The federal government should therefore consider developing standardized tools and metrics for this analysis. There are some existing tools available to federal agencies, ${ }^{329}$ such as the NEMS, but there are several drawbacks to these tools. First, the use of these tools often requires special expertise (NEMS, for example, was developed primarily for use by EIA modelers who understand its structuring and programming). Second, none of these tools can be used to automatically generate information about the effect of a fossil fuel production or transportation project on both energy mar-

327. Peter Erickson \& Michael Lazarus, Stockholm Environment Institute, AsSessing the Greenhouse Gas Emissions Impact of New Fossil Fuel InfrastrucTURE 2-3 (2013).

328. Id. at 6 .

329. The Appendix contains a list of these tools. 
kets and greenhouse gas emissions (a multi-pronged analysis is required to develop this information). It would be beneficial for federal agencies to have access to a tool that allows them to input basic information, e.g., about the quantity of the fossil fuel that will be produced as a result of the proposed project, and generate results describing both the effects on energy markets and the corresponding greenhouse gas emissions. This would streamline the review process and ensure consistency in the market analysis for different projects.

When developing a tool for conducting this analysis, the federal government should refer to the most current data on energy prices and markets, while also accounting for policies and plans aimed at reducing greenhouse gas emissions and dependence on fossil fuels. In other words, the baseline scenario for the market analysis should not correspond with "business-as-usual" trajectories for energy use and emissions (as has been the case in past EIA Reference Case scenarios) but rather trajectories that are consistent with our greenhouse gas reduction targets, and which reflect the effects of current and planned regulations on fossil fuel consumption. In addition, the tool should not only evaluate the extent to which the project will increase the rate of extraction and consumption in its market analysis, but also whether the project will increase the duration of extraction and consumption in the long-term. Finally, the tool should be developed and periodically revised with extensive input from the scientific community and the public at large.

If an agency forgoes a market analysis in its EIS, it would be appropriate to include a statement acknowledging that the net or incremental impact of the proposed action on greenhouse gas emissions may be smaller than the gross emissions listed in the inventory, since the action may displace production of fossil fuels from other sources. But under no circumstances should the agency state that the project will have no effect on emissions as compared with the no action alternative because there are "perfect substitutes" for the produced fuel. As discussed throughout this paper, such an assertion is factually wrong and has been rejected by the courts.

\section{CONCLUSION}

Federal agencies have a legal obligation to consider indirect effects, including upstream and downstream greenhouse gas emissions, when conducting NEPA reviews of fossil fuel extraction and transportation projects. By conducting a comprehensive greenhouse gas assessment like that described in Part $\mathrm{V}$, federal agencies can improve their chances in lawsuits, provide valuable information to decision-makers and the public, and ensure that their decisions are in harmony with national climate goals and the public interest. Some agencies have already begun to conduct this type of analysis in their EISs, in large part due to the judicial intervention described above. It is likely that the public and the courts will continue to play a key role in enforcing NEPA's requirements in 
this context, at least in the near future. Thus, it will be important for interested stakeholders to continue to monitor, comment on, and challenge NEPA reviews as necessary to compel consideration of upstream and downstream emissions. 


\section{Appendix: Estimating Life-Cycle Greenhouse Gas Emissions FROM Fossil Fuels}

There are a variety of tools that can be used to estimate the indirect greenhouse gas emissions from fossil fuel production and transportation projects. Table A-1 lists the protocols that can be used to identify the scope of upstream and downstream activities and physical sources that should be included in the analysis. Table A-2 lists models that can be used to estimate: (i) upstream and downstream greenhouse gas emissions, and (ii) effects of fossil fuel extraction and transportation projects on supply and demand. Table A-3 lists some of the life-cycle assessments ("LCAs") and other studies of greenhouse gas emissions from fossil fuel production, transportation, and consumption in the United States.

\section{Table A-1: Protocols and Models for Identifying and Estimating Greenhouse Gas Emissions from Fossil Fuel Production, Transport, Processing, and End Use}

\begin{tabular}{|c|c|}
\hline Resource & Description \\
\hline $\begin{array}{l}\text { Greenhouse Gas } \\
\text { Protocol }^{330}\end{array}$ & $\begin{array}{l}\text { The Greenhouse Gas Protocol, developed by the World Resources } \\
\text { Institute and World Business Council on Sustainable Development, is } \\
\text { the most widely used international accounting tool for identifying, } \\
\text { quantifying, and managing greenhouse gas emissions. It serves as a } \\
\text { foundation for other greenhouse gas reporting standards, such as those } \\
\text { outlined by the Climate Registry (see below). } \\
\text { The protocol separates emissions into three scopes. Scope } 3 \text { emissions } \\
\text { include downstream and upstream emissions that occur as a } \\
\text { consequence of projects but are generated from sources owned or } \\
\text { controlled by other entities in the value chain (e.g., emissions from the } \\
\text { extraction, production, and transportation of fuels purchased by a } \\
\text { business). } \\
\text { The main protocol is accompanied by several guidance documents and } \\
\text { methodologies, including: } \\
\text { - Scope } 3 \text { Calculation Guidance - This includes targeted guidance on } \\
\text { calculating Scope } 3 \text { emissions for fuel and energy-related } \\
\text { activities. This guidance primarily discusses how entities should } \\
\text { calculate upstream emissions of purchased fossil fuels, such as }\end{array}$ \\
\hline
\end{tabular}

330. About the Greenhouse Gas Protocol, World Res. Inst. \& World Bus. Council on Sustainable Dev., https://perma.cc/8GNX-MXYQ; Corporate Value Chain (Scope 3) Accounting and Reporting Standard, World Res. Inst. \& World Bus. Council on Sustainable Dev., https://perma.cc/LFF6-F9BX; Greenhouse Gas Protocol, World Res. Inst. \& World Bus. Council on Sustainable Dev., https://perma.cc/GE8X-E8KF; Potential Emissions from Fossil Fuels, World Res. Inst. \& World Bus. Council on Sustainable Dev., https://perma.cc/UFX7-KMMP; Scope 3 Calculation Guidance, World Res. Inst. \& World Bus. Council on Sustainable Dev., https://perma.cc/ K59K-JMNJ. 


\begin{tabular}{|c|c|}
\hline & $\begin{array}{l}\text { emissions from mining, transport, and processing. } \\
\text { - Draft Framework Methodology: Calculating and Reporting the } \\
\text { Potential GHG Emissions from Fossil Fuel Reserves - This is a } \\
\text { supplemental tool for quantifying emissions from fossil fuel } \\
\text { reserves. It concentrates on the primary routes through which the } \\
\text { carbon stored in those reserves is released into the atmosphere } \\
\text { (e.g., fuel extraction and processing; flaring, fugitive, and venting } \\
\text { emissions combustion of fuel products by consumers). }\end{array}$ \\
\hline $\begin{array}{l}\text { Oil and Gas } \\
\text { Production } \\
\text { ("O\&GP") } \\
\text { Protocoll }^{331}\end{array}$ & $\begin{array}{l}\text { The O\&GP Protocol was designed as an appendix to the Climate } \\
\text { Registry's General Reporting Protocol (which encourages the } \\
\text { consideration of Scope } 3 \text { emissions in accordance with the Greenhouse } \\
\text { Gas Protocol standards, noted above). } \\
\text { The O\&GP Protocol specifies a methodology for calculating emissions } \\
\text { from the production and transportation of oil and gas. Some aspects of } \\
\text { processing are also covered. } \\
\text { It does not address certain downstream activities. Specifically, for oil, it } \\
\text { does not address refining, transportation, storage and distribution of } \\
\text { petroleum products. For natural gas, it does not address emissions from } \\
\text { transmission, storage, and distribution. It does not address emissions } \\
\text { from combustion or end use of any fuel. }\end{array}$ \\
\hline $\begin{array}{l}\text { Greenhouse Gas } \\
\text { Reporting } \\
\text { Rule }^{332}\end{array}$ & $\begin{array}{l}\text { EPA's Greenhouse Gas reporting rule outlines requirements for } \\
\text { reporting emissions from certain source categories. The rule describes: } \\
\text { - The scope of emissions to be reported. } \\
\text { - The methodology that should be used to report emissions from } \\
\text { those sources. } \\
\text { - Procedures for estimating missing data. Specific requirements are } \\
\text { outlined for the following source categories: } \\
\text { - Subpart C - General Stationary Fuel Combustion Sources } \\
\text { - Subpart D - Electricity Generation } \\
\text { - Subpart W - Petroleum and Natural Gas Systems } \\
\text { - Subpart Y - Petroleum Refineries } \\
\text { - Subpart FF - Underground Coal Mines } \\
\text { - Subpart MM- Suppliers of Petroleum Products } \\
\text { - Subpart NN - Suppliers of Natural Gas and Natural Gas } \\
\text { Liquids } \\
\text { While the rule only provides instructions on how to calculate direct } \\
\text { emissions from each category, it could be referred to for the purpose of } \\
\text { calculating indirect emissions associated with specific upstream or } \\
\text { downstream activities. The data acquired through the rule could also be } \\
\text { helpful for the purposes of conducting a LCA of fossil fuels. }\end{array}$ \\
\hline
\end{tabular}

331. Oil and Gas Production Protocol, The Climate Registry, https://perma.cc/Z5SF-E6TQ.

332. Greenhouse Gas Reporting Rule, 81 Fed. Reg. 86,490 (Nov. 30, 2016) (codified at 40 C.F.R. pt. 98). 
Table A-2: Models to Calculate Greenhouse Gas Emissions and Impacts on Fossil Fuel Supply and Demand

\begin{tabular}{|l|l|}
\hline Resource & Description \\
\hline $\begin{array}{l}\text { National Energy } \\
\text { ModelingSystem } \\
\text { ("NEMS") }\end{array}$ & $\begin{array}{l}\text { This tool, developed by the U.S. Environmental Information } \\
\text { Administration, can be used to: (i) forecast the impacts of fossil fuel } \\
\text { extraction and transportation projects on supply and demand, and (ii) } \\
\text { quantify the corresponding environmental impacts, including } \\
\text { greenhouse gas emissions. }\end{array}$ \\
\hline $\begin{array}{l}\text { Upstream } \\
\text { Dashboard }\end{array}$ & $\begin{array}{l}\text { The National Energy Technology Laboratory developed this tool to } \\
\text { calculate upstream emissions from fossil fuels and other energy } \\
\text { feedstocks. It is an excel-based tool, which breaks down energy } \\
\text { production and emissions into the lifecycle stages of extraction and } \\
\text { transportation, and allows the user to customize the analysis by } \\
\text { changing options such as the mode of transportation, distance the raw } \\
\text { material travels, and the sub-type of fuel. }\end{array}$ \\
\hline $\begin{array}{l}\text { Greenhouse } \\
\text { Gases, Regulated } \\
\text { Emissions, and } \\
\text { Energy Use in } \\
\text { Transportation } \\
\text { (“GREET") }\end{array}$ & $\begin{array}{l}\text { GREET is a model that can be used to estimate both upstream and } \\
\text { downstream emissions of different fossil fuels, including emissions from } \\
\text { the extraction, processing, transportation and combustion (both } \\
\text { stationary and mobile source) of petroleum, natural gas, and coal. }\end{array}$ \\
\hline $\begin{array}{l}\text { OilProduction } \\
\text { GHGEmissions } \\
\text { Estimator } \\
\text { ("OPGEE") }\end{array}$ & $\begin{array}{l}\text { The OPG } \\
\text { of greenhouse gas emissions from the production, processing, and } \\
\text { transport of crude petroleum. The system boundary of OPGEE extends } \\
\text { from initial exploration to the refinery entrance gate. }\end{array}$ \\
\hline $\begin{array}{l}\text { Integrated North } \\
\text { American } \\
\text { Power, Coal, } \\
\text { and World Gas } \\
\text { Model }\end{array}$ & $\begin{array}{l}\text { This model, also known as the "World Gas Model," can be used to } \\
\text { estimate both price and quantity impacts from natural gas supply and } \\
\text { transportation projects (and as such, can be paired with other emissions } \\
\text { modeling tools to estimate emissions associated with increases in } \\
\text { natural gas production and consumption) }\end{array}$ \\
\hline
\end{tabular}

333. U.S. Energy Info. Admin., The National Energy Modeling System: An Overview (2009).

334. New Tool Yields Custom Environmental Data for Lifecycle Analysis, U.S. Dep'T of EnERGy (Sept. 10, 2012), https://perma.cc/4Z28-HNVW.

335. GREET Model, Argonne Nat'L Lab., https://perma.cc/6MFD-NSPT.

336. OPGEE: The Oil Production Greenhouse Gas Emissions Estimator, StAnford Sch. OF EARTh, Energy \& Envtl. Scis., https://perma.cc/WX9X-QFVN.

337. Natural Gas Models, Deloitte MarketPoint, https://perma.cc/755F-V2SH. 


\section{Table A-3: Life-Cycle Assessment of Greenhouse Gas Emissions FROM FosSIL FuELS}

\begin{tabular}{|c|c|c|}
\hline Resource & FossilFuels & Stages \\
\hline Jaramillo et al. $(2007)^{338}$ & $\begin{array}{l}\text { Coal, natural gas (including } \\
\text { LNG and SNG) }\end{array}$ & $\begin{array}{l}\text { Extraction, processing, trans- } \\
\text { mission, consumption. } \\
\text { For LNG, includes liquefac- } \\
\text { tion and regasification. }\end{array}$ \\
\hline Burnham et al. (2012) & $\begin{array}{l}\text { Natural gas (including shale), } \\
\text { coal, petroleum }\end{array}$ & $\begin{array}{l}\text { Extraction, processing, trans- } \\
\text { mission and storage, distribu- } \\
\text { tion, consumption (unclear } \\
\text { whether coal transport was } \\
\text { accounted for). }\end{array}$ \\
\hline $\begin{array}{l}\text { Congressional Research Service } \\
(2015)^{340}\end{array}$ & Coal, natural gas & $\begin{array}{l}\text { Extraction, processing, trans- } \\
\text { port, combustion. }\end{array}$ \\
\hline $\begin{array}{l}\text { US DOE, Natural Gas Produc- } \\
\text { tion and Use }(2014)^{341}\end{array}$ & Coal, natural gas & $\begin{array}{l}\text { Extraction, processing, trans- } \\
\text { port, combustion. }\end{array}$ \\
\hline $\begin{array}{l}\text { US DOE, Natural Gas Exports } \\
(2014)^{342}\end{array}$ & Coal, natural gas & $\begin{array}{l}\text { Extraction, processing, trans- } \\
\text { port, export, combustion. }\end{array}$ \\
\hline Abrahams et al. (2014) & Natural Gas (LNG Exports) & $\begin{array}{l}\text { Extraction, processing, pipeline } \\
\text { transportation to liquefaction } \\
\text { facility, liquefaction, shipping, } \\
\text { regasification, distribution, } \\
\text { combustion. }\end{array}$ \\
\hline Jiang et al. $(2011)^{344}$ & Natural gas (Marcellus Shale) & $\begin{array}{l}\text { Exploration, extraction, } \\
\text { processing, transmission, dis- } \\
\text { tribution, combustion. }\end{array}$ \\
\hline $\begin{array}{l}\text { World Resources Institute } \\
(\mathbf{2 0 1 3})^{345}\end{array}$ & Natural gas & $\begin{array}{l}\text { Pre-production, production, } \\
\text { processing, transmission, com- } \\
\text { bustion. }\end{array}$ \\
\hline
\end{tabular}

338. Paulina Jaramillo et al., Comparative Life-Cycle Air Emissions of Coal, Domestic Natural Gas, $L N G$, and SNG for Electricity Generation, 41 EnVTL. SCI. \& TECH. 6290 (2007).

339. Andrew Burnham et al., Life-Cycle Greenhouse Gas Emissions of Shale Gas, Natural Gas, Coal, and Petroleum, 46 Envtl. Sci. \& Tech. 619 (2012).

340. Richard K. Lattanzio, Cong. Research Serv., R44090, Life-Cycle Greenhouse Gas Assessment of Coal and Natural Gas in the Power Sector (2015).

341. U.S. Dep't of Energy, Nat'l Energy Tech. Lab., Life Cycle Analysis of Natural Gas Extraction and Power Generation, DOE/NETL-2014/1646 (2014). (Although the report focuses on natural gas LCA, it also includes coal LCA for the purpose of comparison).

342. U.S. Dep’t of Energy, Nat. Energy Tech. Lab., Life Cycle Greenhouse Gas Perspective on Exporting Liguefied Natural Gas from the United States, DOE/NETL-2014/1649 (2014). (Although the focus is on natural gas, coal is also evaluated for comparison).

343. Leslie S. Abrahams et al., Life Cycle Greenhouse Gas Emissions from U.S. Liquefied Natural Gas Exports: Implications for End Uses, 49 EnvTL. ScI. \& TeCH. 3237 (2015).

344. Mohan Jiang et al., Life Cycle Greenhouse Gas Emissions of Marcellus Shale Gas, 6(3) ENVTL. Res. LetTers 034014 (2011).

345. James Bradbury et al., Clearing the Air: Reducing Upstream Greenhouse Gas Emissions from U.S. Natural Gas Systems (World Res. Inst., Working Paper, Apr. 2013). 


\begin{tabular}{|c|c|c|}
\hline Weber \& Clavin $(2012)^{346}$ & Natural gas (shale gas) & $\begin{array}{l}\text { Preproduction, production/ } \\
\text { processing, transmission. }\end{array}$ \\
\hline Zavala-Araiza et al. $(2015)^{347}$ & $\begin{array}{l}\text { Oil, gas (supply chain methane } \\
\text { emissions) }\end{array}$ & $\begin{array}{l}\text { Production, transmission, } \\
\text { processing. }\end{array}$ \\
\hline Epstein et al. (2011) 348 & Coal & $\begin{array}{l}\text { Extraction, transport, process- } \\
\text { ing, combustion. }\end{array}$ \\
\hline
\end{tabular}

346. Christopher L. Weber \& Christopher Clavin, Life Cycle Carbon Footprint of Shale Gas: Review of Evidence and Implications, 46 (11) ENVTL. SCI. \& TECH. 5688 (2012).

347. Daniel Zavala-Araiza et al., Reconciling Divergent Estimates of Oil and Gas Methane Emissions, 112 PNAS 15597 (2015), https://perma.cc/WU2A-UGVE.

348. Paul R. Epstein et al., Full Cost Accounting for the Life Cycle of Coal, 1219 AnnALs N.Y. ACAD. SCI. 73 (2011). 
